
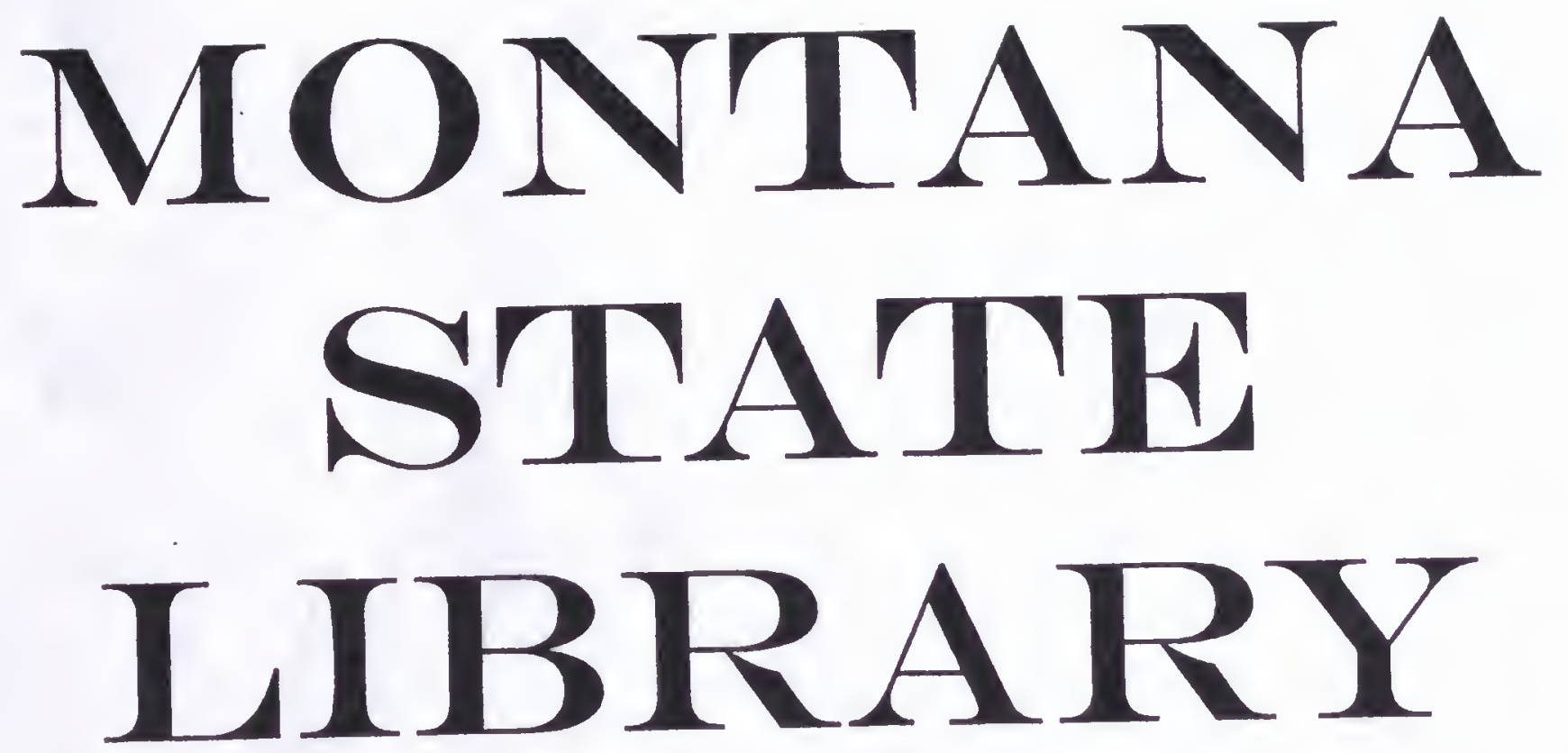

This "cover" page added by the Internet Archive for formatting purposes 



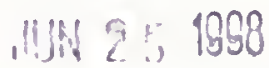

MONTANA GTATE LIBRARY.

1515 E. 6th AVE.

HELENA, MONTANA 59620

\section{CONSERVATION STATUS OF \\ SPIRANTHES DILUVIALIS Sheviak IN MONTANA}

Taxon Name:

Common Name:

Family:

States Where Taxon Occurs:

Current Federal Status:

Recommended Federal Status:

Author of Report:

Original Date of Report:

Date of Most Recent Revision: March 1998

Individual to Whom Further Information and Comments Should be Sent:

Orchidaceae

Threatened

April 1997
Spiranthes diluvialis Sheviak

Ute ladies'-tresses

Colorado, Idaho, Montana, Nebraska, Nevada, Utah, Washington, Wyoming

This state status information is necessary but not sufficient in determining rangewide status.

Bonnie L. Heidel

Bonnie L. Heidel

Montana Natural Heritage Program

State Library

1515 East Sixth Avenue

Helena, MT 59620-1800

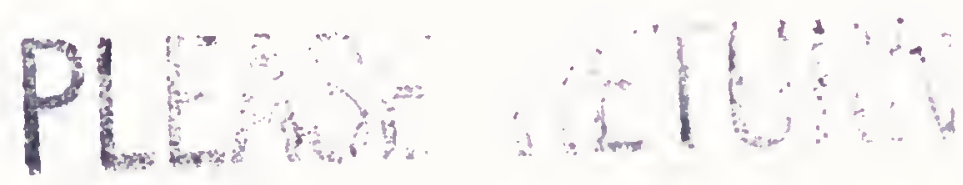




\section{(C) 1998 Montana Natural Heritage Program}

This status report should be cited as follows:

Heidel, B. L. 1998. Conservation status of Spiranthes diluvialis Sheviak in Montana. Unpublished report to U.S. Fish and Wildlife Service. Montana Natural Heritage Program, Helena. 55 pp. + app. 


\section{SUMMARY}

Ute ladies'-tresses has been systematically surveyed across potential habitat spanning eight counties, based on three primary search criteria that were ground-truthed and extrapolated in the field. The survey methodology included interpretation of aerial photography in all eight counties, interpretation of soil survey maps for those three counties having published soil surveys, and survey at or around the places where two other rare species that are closely associated with Ute ladies'-tresses have been collected. Vegetation and soils data were collected at representative sites of Ute ladies'-tresses to document habitat conditions.

The distribution of Ute ladies'-tresses has been circumscribed in western Montana, where it is known from four counties in intermontane valleys centered on the Jefferson River, and confluent lower reaches of the Gallatin, Madison, Beaverhead and Ruby rivers. While this spans app. 80 miles of valley, the species is in a highly restricted microhabitat that falls within four soil series, within them to shallow meandered wetlands, and within these wetlands to small pockets of sparse, highly calcareous meadow.

Ten occurrences have been documented, doubling the total number previously known. Two of the largest had flowering plant numbers approaching or exceeding 500 individuals in 1997. Small populations or population segments were found on three small tracts of state land but the balance are on private property. Occurrences in Montana represent over 10\% of known occurrences rangewide, but likely less than $10 \%$ of total numbers of plants rangewide.

All Montana populations are vulnerable and unprotected but are not under immediate threats. Priority conservation tasks include: conveyance of species information to land managing and regulatory agencies and to agencies that work with private landowners, delimitation of potential habitat for Sec. 7 reference purposes in Montana, expanded systematic survey at those EOs where boundaries have not been delimited, noxious weed control, determination of the pollinator and its habitat requirements, refinement and analysis of the monitoring work, hydrological consultation, comparison of rangewide genetic resources, and coordination with other researchers working on the species. 


\section{ACKNOWLEDGEMENTS}

The access permission and kindness of all landowners whose property was visited in this study are acknowledged with deep appreciation. Special thanks are given the landowner at the site where Spiranthes diluvialis was first discovered for permission to conduct annual monitoring.

Taxonomic consultation and chromosome analysis were graciously provided by Dr. Charles Sheviak (New York Biological Survey). Information and assistance provided by Walter Fertig (Wyoming Natural Diversity Database) and Dr. Lawrence Magrath (University of Oklahoma) initially helped identify the possibility of Spiranthes diluvialis occurring in Montana. The taxonomic expertise of Dr. Anton Reznicek, Dr. Rupert Barneby, and Dr. Jim Ratter in determining and verifying associated species is also acknowledged, as is the associated species documentation provided by Peter Lesica.

The synthesis of listing and recovery information and the coordination promoted by the U. S. Fish and Wildlife Service fostered rangewide information exchange. The author acknowledges the contributions of all whose works are cited in this report, and thanks the following individuals for sending Spiranthes diluvialis information: Jeff Carroll (Bureau of Land Management - Wyoming), Walter Fertig, John Gamon (Washington Natural Heritage Program), Dr. Lucy Jordan (U. S. Fish and Wildlife Service), Bob Moseley (Idaho Conservation Data Center), Lynn Riedel (Dinosauer National Monument), Susan Spackman (Colorado Natural Heritage Program), and Gerry Steinaeur (Nebraska Natural Heritage Program). Visits to Idaho sites were made in conjunction with a tour jointly led by Edna Rey-Vizgirdas (U.S. Fish and Wildlife Service) and Bob Moseley (Idaho Conservation Data Center).

Permission to reproduce illustrations of Spiranthes diluvialis was provided by the illustrator, Carolyn Crawford, and close-up photographs of Spiranthes diluvialis by the photographer, Kristi DuBois. These graphics were scanned and printed by Anne Dalton (Montana Natural Heritage Program) who also produced the state distribution map. The rangewide distribution map was provided by Dr. Ronald Hartman (University of Wyoming). Montana element occurrences were processed with the assistance of Anne Dalton, Katie Schletz and other data management staff. Stratification of the vegetation sampling data was run with help from Steve Cooper and Scott LeeChadde (Montana Natural Heritage Program). The coordination of soils analysis between states was provided by Gerry Steinauer and the tabulation of soils results was provided by Terri Hildebrand (contractor to Nebraska Game \& Parks Commission).

Use of the Montana Department of Natural Resource and Conservation aerial photos and site visits to state lands were coordinated through the Central Land Office and the Dillon Unit Office, by Robert and Stanley Vlahovich, respectively. The well-organized aerial photographs and the helpfulness of Farm Service Agency personnel in the Bozeman, Deerlodge, Dillon and Whitehall offices made the extensive review of aerial photographs possible. This study was conducted as two challenge cost-share projects in 1996 and 1997 with the support of the U.S. Fish and Wildlife Service and the Montana Natural Heritage Program. 


\section{TABLE OF CONTENTS}

Page

\section{SPECIES INFORMATION}

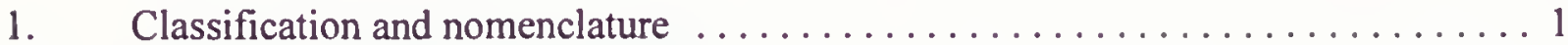

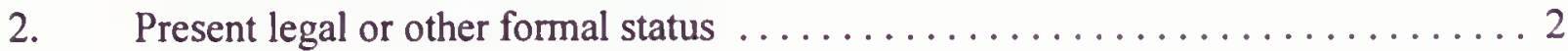

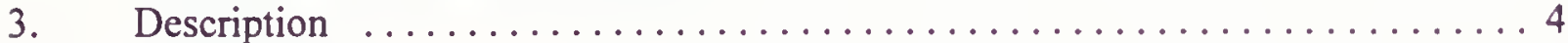

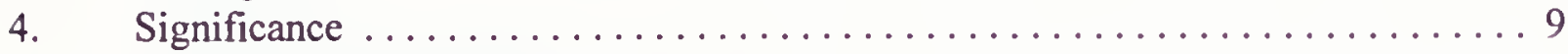

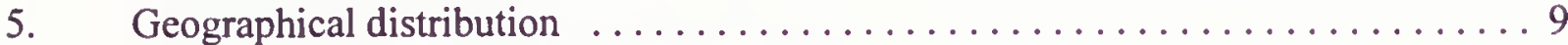

6. General environment and habitat description $\ldots \ldots \ldots \ldots \ldots \ldots \ldots \ldots \ldots \ldots \ldots$

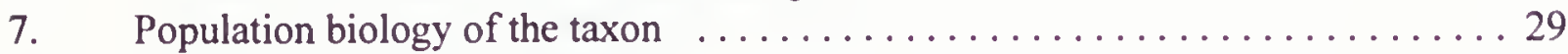

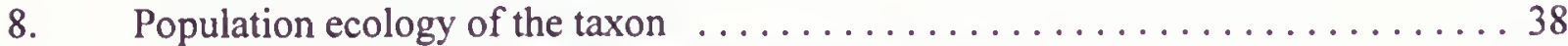

9. Current land ownership and management responsibility ............. 40

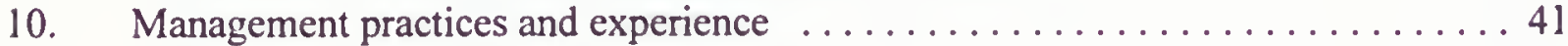

11. Evidence of threats to survival .......................... 44

\section{ASSESSMENT AND RECOMMENDATIONS}

12. General assessment of vigor, trends, and status ................ 46

13. Recommendations for listing or status change $\ldots \ldots \ldots \ldots \ldots \ldots \ldots$

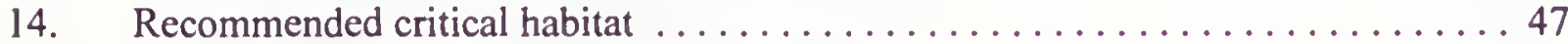

15. Conservation $/$ recovery recommendations $\ldots \ldots \ldots \ldots \ldots \ldots \ldots \ldots \ldots \ldots \ldots \ldots$

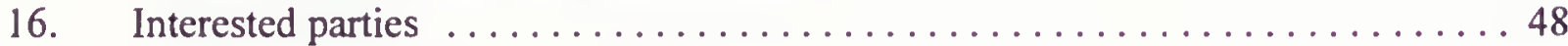

\section{INFORMATION SOURCES}

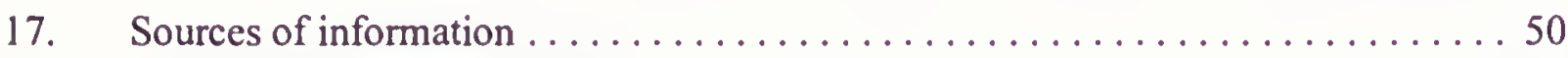

18. Summary of materials on file ........................... 51

\section{AUTHORSHIP}

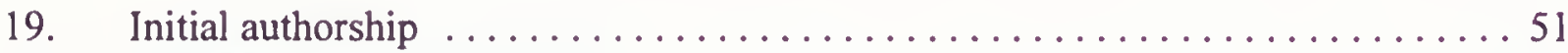

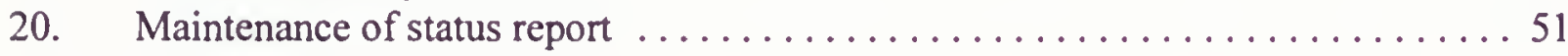

NEW INFORMATION

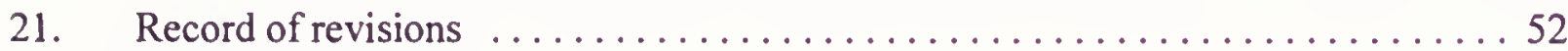

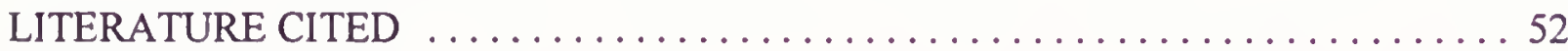




\section{FIGURES}

Figure 1. Spiranthes diluvialis; the whole plant

Figure 2. Comparative illustration of the enlarged flowers of S. diluvialis, S. romanzoffiana, S. magnicamporum and S. porrifolia.

Figure 3. Spiranthes diluvialis distribution rangewide

Figure 4. Spiranthes diluvialis distribution in Montana

Figure 5. Spiranthes diluvialis landscape setting in Montana

Figure 6. Wetland complexes of a representative section with potential Spiranthes diluvialis habitat

Figure 7. Vegetation gradient profile through Spiranthes diluvialis habitat

\section{TABLES}

Table 1. Comparison of diagnostic features of Spiranthes diluvialis with $S$. porrifolia, S. romanzoffiana, and S. magnicamporum

Table 2. Spiranthes diluvialis locations in Montana

Table 3. Comparison of soil parameters at Spiranthes diluvialis sites

\section{APPENDIX}

Appendix A. Element occurrence printouts

Appendix B. Close-up and habitat photos

Appendix C. Species associated with Spiranthes diluvialis in Montana and rangewide

Appendix D. Demographic monitoring

Appendix E. DRAFT - Section 7 guidelines for Spiranthes diluvialis in Montana

Appendix F. Soils data analysis from Spiranthes diluvialis sites

Appendix G. Vegetation sampling data stratification from Spiranthes diluvialis microplots 




\section{SPECIES INFORMATION}

1. Classification and nomenclature.

A. Species.

\section{Scientific name}

a. Binomial: Spiranthes diluvialis Sheviak.

b. Full bibliographic citation: Sheviak, C.J. 1984. Spiranthes diluvialis (Orchidaceae), a new species from the western United States. Brittonia 36(1):8-14.

c. Type specimens: United States, Colorado, Jefferson Co.: mesic to wet alluvial meadows along Clear Creek just west of junctions of Routes 6 \& 58, Golden, 17 July 1982, C. J. Sheviak, J. K Sheviak, $W$. Jennings, L. Long \& S. Smookler \#2257. Holotype: NYS; isotype NY.

2. Pertinent synonyms: None.

3. Common name: Ute ladies'-tresses

4. Taxon codes: PMORC2B100 (The Nature Conservancy); SPIDIL (U.S. Forest Service, Region 1)

5. Size of genus: Spiranthes is a genus which is treated by some authors as including 200 or more species; by others as having less than 100 species. The genus in either case is largely confined to temperate areas of both the New and Old World (Hitchcock et al. 1984).

B. Family classification.

1. Family name: Orchidaceae.

2. Pertinent family synonym: None.

3. Common names for the family: Orchid Family. It represents the largest family of vascular plants in the world, including app. one out of every ten species (Smith 1977).

C. Major plant group: Monocotyledonae. 
D. History of knowledge of taxon: Prior to the description of S. diluvialis in 1984, workers in Orchidaceae had tried to classify specimens from the western United States in three taxa of white-flowered Spiranthes: Spiranthes cernua L. C. Richard, Spiranthes romanzoffiana Chamisso, and Spiranthes porrifolia Lindley.

In 1980, a specimen of Spiranthes was collected near Golden, Colorado, that appeared to be $S$. cernua. In 1981, live plants were collected at that site and sent to Dr. Charles Sheviak, who had initiated taxonomic studies on the genus Spiranthes in the early 1970's. In 1982 and 1983, Dr. Sheviak visited Colorado and Utah. After examining herbarium specimens and live plants in the field, and after cytologic study, Dr. Sheviak described the Colorado-Utah plants as a new species (Sheviak 1984; from U.S. Fish and Wildlife Service 1992).

E. Comments on current alternative taxonomic treatments: There are no known current alternative taxonomic treatments.

2. Present legal or other formal status.

\section{A. International.}

1. Present designated or proposed legal protection or regulation: As a member of the Orchid Family (Orchidaceae), Spiranthes diluvialis is included on the CITES Appendix II list. Species listed in Appendix II require a permit from the country of origin prior to export. International trade in this species has not been documented.

2. Other current formal status recommendations: None.

B. National.

1. United States.

a. Present designated or proposed legal protection or regulation: The Ute ladies'-tresses (Spiranthes diluvialis) was listed as a threatened species on January 17, 1992 (57 FR 2053 under the authority of the Endangered Species Act of 1973 (Act) as amended (U.S. Fish and Wildlife Service 1992).

b. Other current formal status: It is not known from federal lands in Montana. It has been placed on the watch list for the Bureau of Land Management (USDI BLM 1996). 
Federal agencies recognize species protected under the Endangered Species Act, and the U.S. Fish and Wildlife Service has developed draft Section 7 consultation guidelines for addressing potential impacts (U. S. Fish and Wildlife Service 1995a.)

c. Review of past status: In addition to the original listing document (U.S. Fish and Wildlife Service 1992) and draft Section 7 consultation guidelines (U.S. Fish and Wildlife Service 1995a), the U.S. Fish and Wildlife Service has prepared a draft recovery plan (U.S. Fish and Wildlife Service 1995b).

\section{State.}

a. Montana. Spiranthes diluvialis was first discovered in Montana in 1994, and sent to Dr. Charles Sheviak for determination. He provisionally identified it as Spiranthes diluvialis. It was treated as unconfirmed until cytological determination was made by Dr. Sheviak in 1995 (Heidel 1995). It was published as a new addition to the state flora the following year (Heidel 1996a).

i. Present designated or proposed legal protection or regulation: Spiranthes diluvialis is currently ranked as "globally imperiled" owing to extreme rarity (global rank = G2; generally 20 or fewer occurrences.) In this case, there are app. 90 occurrences rangewide and this rank was last updated by the Utah Natural Heritage Program in 1984. The rank is conditioned by quality, condition, viability and vulnerability of the occurrences, and the prospective aggregation or interconnectedness of these occurrences along rivers into far fewer occurrences.

It is recognized as an imperiled species of special concern in Montana (state rank $=\mathrm{S} 2$ ), owing to extreme rarity (10 occurrences), small occurrence size, lack of protection, and threats. This rank is not a designation, nor does it afford legal protection or regulation.

\section{ii. Other current formal status recommendations: None.}

iii. Review of past status: NA 


\section{Description.}

A. General nontechnical description: Spiranthes diluvialis is a perennial orchid with mainly 1 stem $12-50 \mathrm{~cm}$ tall, arising from tuberously thickened roots. Its narrow (1 $\mathrm{cm}$ ) leaves can reach $28 \mathrm{~cm}$ long, are longest at the base, and persist during flowering (Figure 1). The inflorescence consists of few to many white or ivory flowers clustered in a spike of 3-ranked spirals at the top of the stem. The sepals and petals are oriented perpendicular to the stem, the lateral sepals often spreading abruptly from the base of the flower, and all sepals are free to the base. The lip petal is somewhat constricted at the median (from U.S. Fish and Wildlife Service 1995b).

B. Technical description: Herb, erect, slender to stout, 20-50 cm tall, glabrous below, pubescent above with numerous capitate trichomes. Roots tuberously thickened, up to $1 \mathrm{~cm}$ in diameter. Leaves linear-lanceolate, the larger to $28 \times 1.5 \mathrm{~cm}$, basal, usually restricted to the very base of the stem and rapidly reduced upward to sheathing bracts, persisting past anthesis. Spike dense, $3-5 \times 1.2-2.5 \mathrm{~cm}$. Floral bracts ovate, attenuate or acuminate, the lower $9-33 \mathrm{~mm}$ long. Flowers $7.5-15 \mathrm{~mm}$ long, faintly fragrant with the scent of coumarin, white or ivory, the lip often yellow centrally. Sepals free or connate at the base, the dorsal lanceolate, acute, the lateral broadly spreading to loosely incurved or appressed, linear-lanceolate, acuminate, Petals connivent with the dorsal sepal, linear, acuminate. Lip 7-12 x 2.5-6.8 mm, ovate, lanceolate, or oblong, with a median constriction and occasionally pandurate, the margin entire or dentate toward the apex, crisped, the basal calli prominent, pubescent. Seeds ellipsoidal, monoembryonic (Sheviak 1984).

C. Local field characters: Spiranthes diluvialis is characterized by whitish, stout, ringent (gaping at the mouth) flowers, with slender, elongate petals and sepals that are white to ivory-colored and free to the base (Figure 2). The lip is exposed in lateral view; with an oval to lance or oblong outline, a marked median constriction, the base usually dilated, the venation mostly parallel, typically with some branching divaricating in the lower half, and with crispy-wavy margins. The upper stem is sparsely to densely pubescent, the longest hairs are longer than $0.19 \mathrm{~mm}$, and the glands are obviously stalked. The persistent leaves are mostly restricted to the base of the stem, reduced to bracts above (adapted from U.S. Fish and Wildlife Service 1995b, Wyoming Technical Plant Committee 1995).

By comparison, S. romanzoffiana has petals and sepals which usually curve in the shape of a hood on top. It has a more deeply constricted lip petal, and more densely congested and shorter spikes compared to $S$. diluvialis. Its numerous leaves often extend up the lower stem (Figure 2). It also differs from Spiranthes diluvialis in Montana in that it occupies mainly montane settings rather than arid bottomlands, though it has been noted in the Eureka Plains of northwestern Montana (Lesica pers. commun.) and in open canyon settings on the upper Madison River in southwestern Montana (pers. obs.). Comparison with similar species is presented in Table 1. 
Figure 1. Spiranthes diluvialis: the whole plant

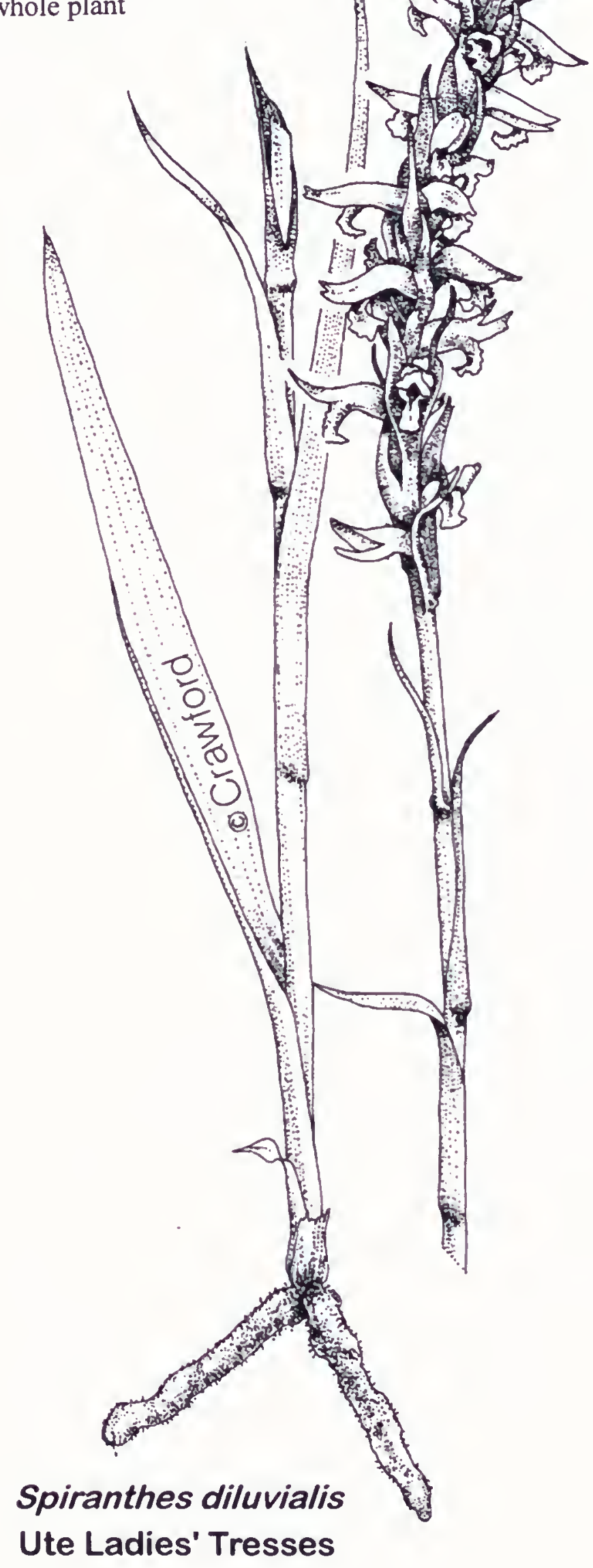


Figure 2. Comparative illustration of the enlarged flowers of Spiranthes diluvialis, Spiranthes romanzoffiana, Spiranthes magnicamporum and Spiranthes porrifolia
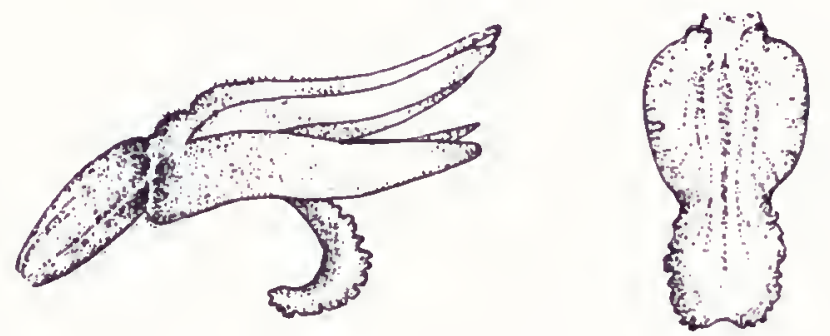

¿FIRANTHES OILIJVIALI" $5 x$
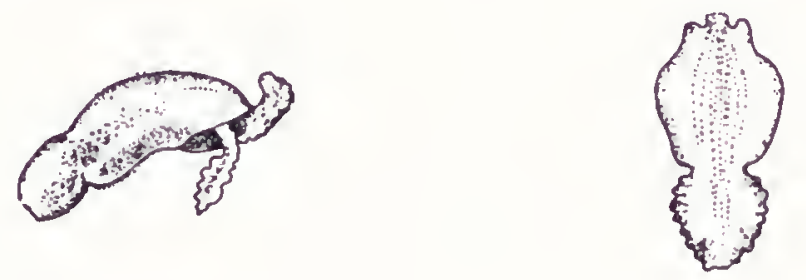

SFIRANTHES ROMANZOFFIANA $5 X$

SPIRANTHES MAGNICAMPORUM
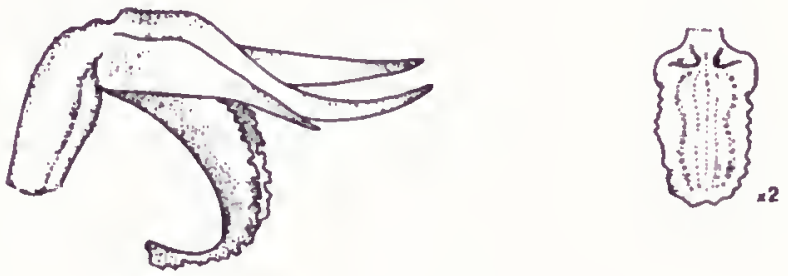

flower. $5 X$ : IID. $2 X$

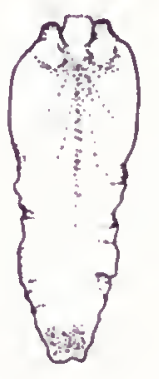

SPIRANTHES PORRIFOLIA $5 X$

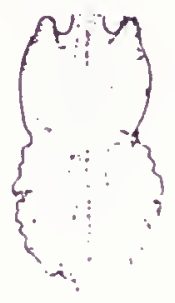

SFIPANTHES CERNUA

$5, \lambda$

By Carolyn Crawford 


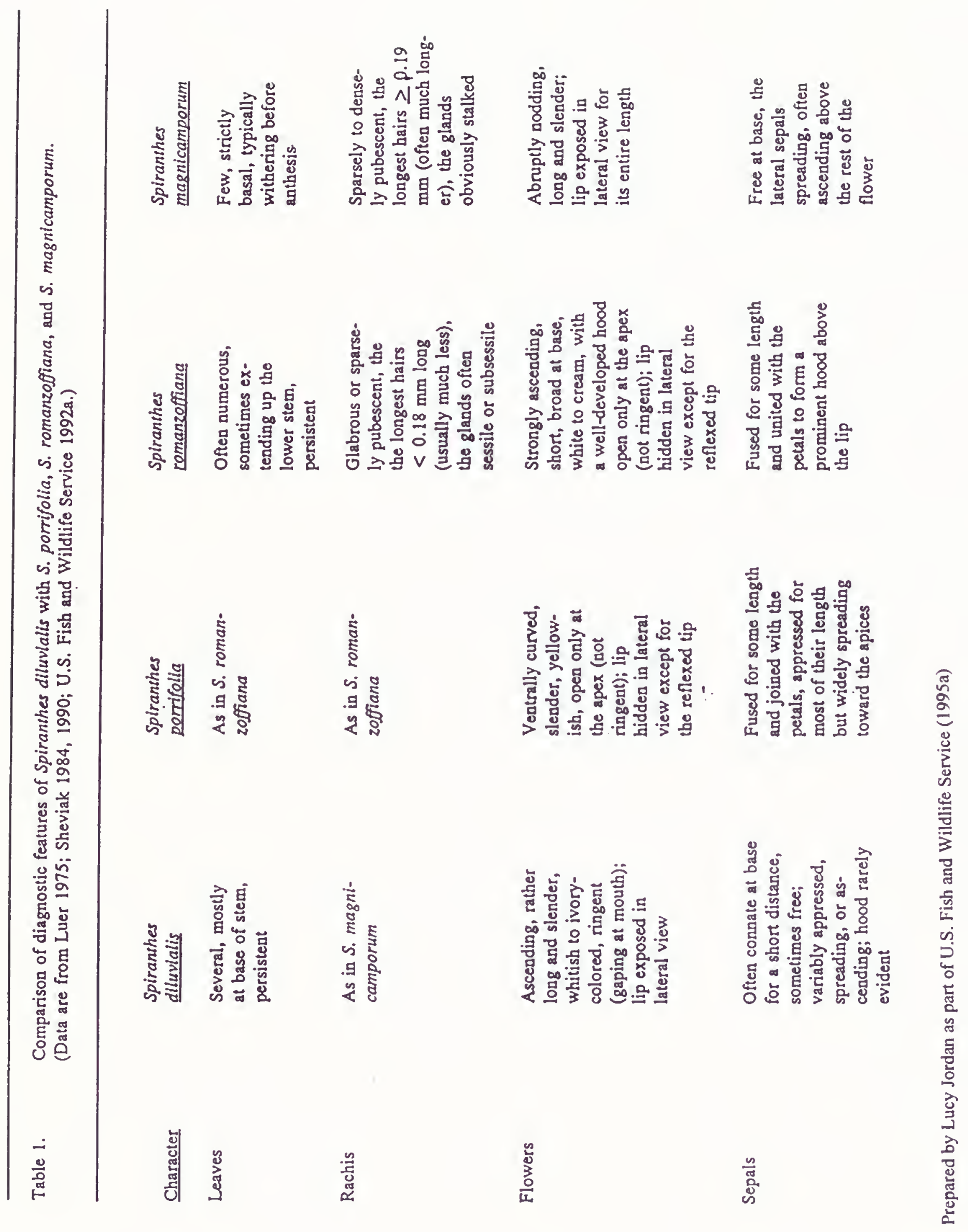




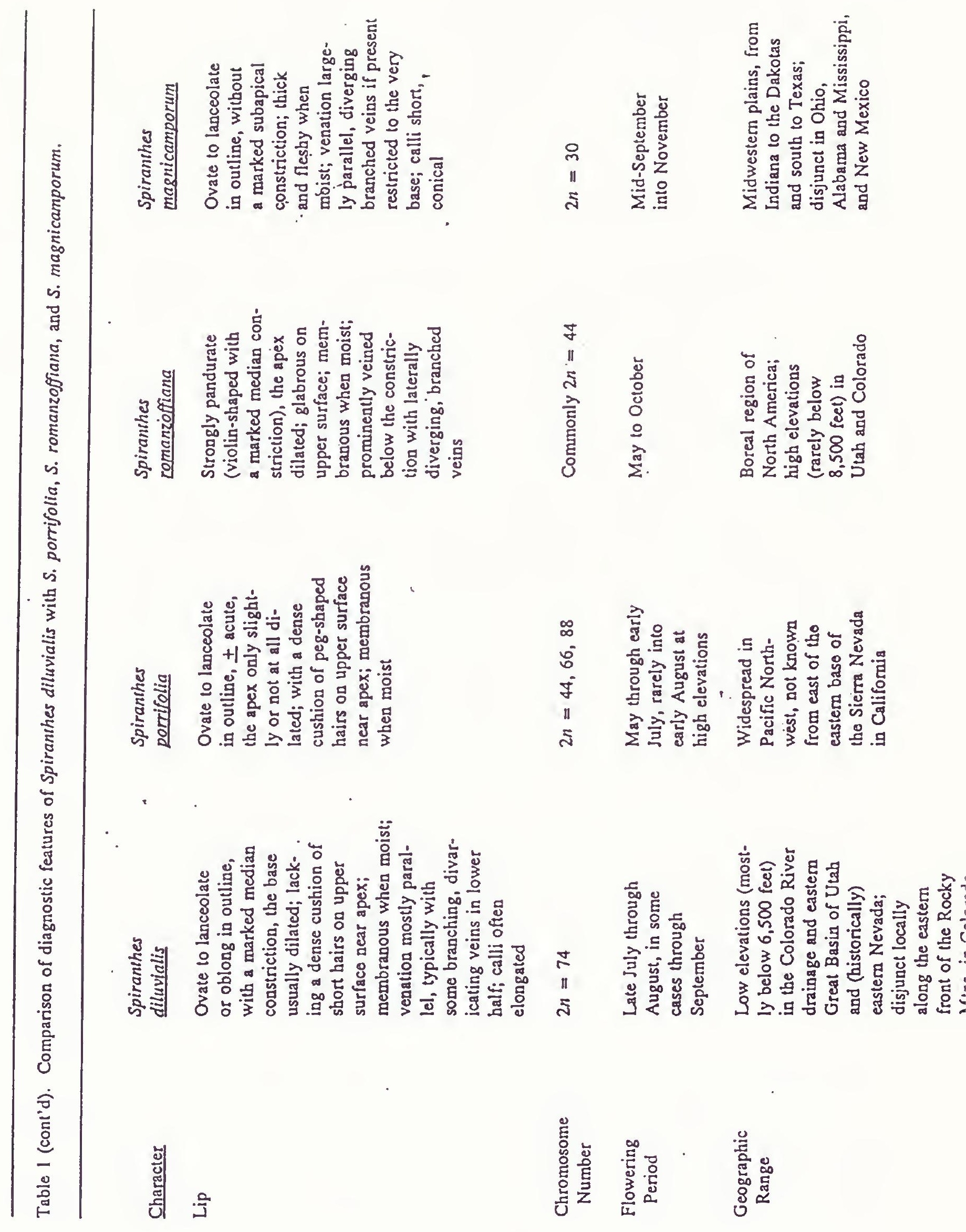




\section{Identifying characteristics of material which is in interstate or international commerce or trade: No interstate commerce or trade is known.}

E. Photographs and line drawings: Figure 1 is an illustration of Spiranthes diluvialis; the whole plant. Figure 2 is a comparative illustration of the flowers of $S$. diluvialis, $S$. romanzoffiana, $S$. magnicamporum and $S$. porrifolia. Color slides of the species were taken in the course of this study and close-ups were sought from photographers. They have been printed as color xeroxes for the report (Appendix B), submitted as slide duplicates, and posted on the Internet. Additional slides of the species and habitat in Montana are housed at the MTNHP office in Helena.

\section{Significance.}

A. Natural: Spiranthes diluvialis is thought to represent an evolutionary product of Pleistocene climates now confined to riparian systems of the semi-arid West. It is associated with riparian successional processes and microhabitats.

It is among the few species of plants with a Rocky Mountains distribution that is confined to low elevations. It is the only orchid species restricted to grasslands as found in Montana, where it is consistently associated with other botanical and wildlife resource features.

B. Human: Spiranthes diluvialis is a showy flowering plant. It has not been successfully propagated to date. The horticultural significance and level of international trade of members of the Orchid Family is recognized by categorical inclusion of all species in the Family under Appendix II of the CITES Act, a subject of widespread interest (Allen 1996).

This species also has scientific significance in studies addressing its evolutionary isolation, which has been an important subject in conservation biology research. Otherwise, the species has no known agricultural, economic, or other human uses at this time.

\section{Geographical distribution.}

A. Geographical range: Spiranthes diluvialis is known from eight states: eastern Nevada (historical), northern and south-central Utah, northern Colorado, eastern Idaho, western Nebraska, southeastern Wyoming, and southwestern Montana. It was collected from northcentral Washington in 1997.

When Spiranthes diluvialis was originally described (Sheviak 1984) and subsequently designated (U. S. Fish and Wildlife Service 1992), it was only known from Colorado and Utah with an historic record in Nevada. It is now known from over twice as many states. The center of distribution is along the Rocky Mountains, 


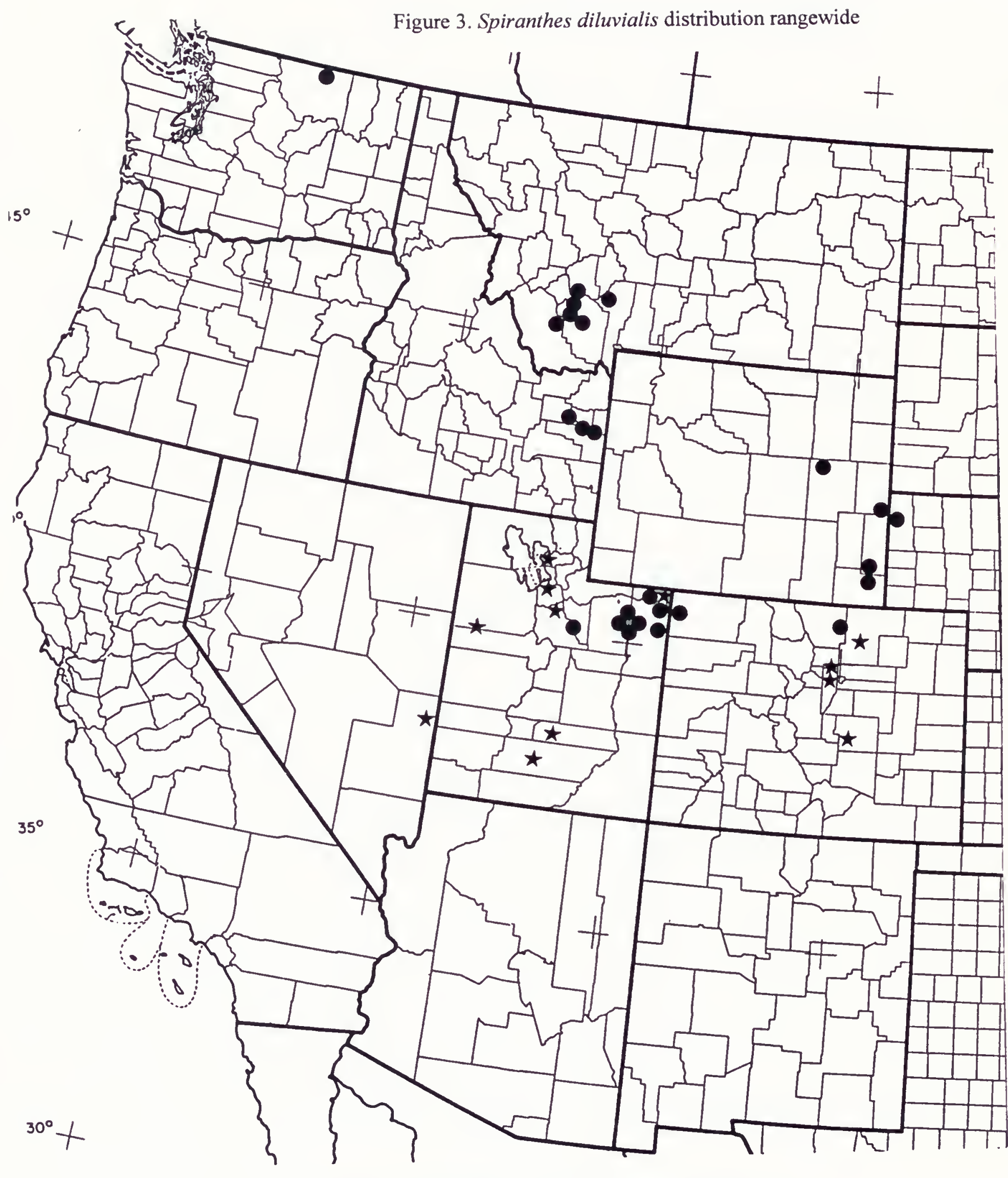

Spiranthes diluvialis -- Ute ladies'-tresses

= populations discovered in the past 5 years, including ones from $I D, M T, N E, W A$, and WY.
市= populations discovered earlier, all have been relocated except the one in NV. 
with outliers in the Great Plains (Nebraska, Wyoming) and the Okanagan Highlands (Washington). In 1993 it was first discovered in Wyoming (Fertig 1994), and in 1994 in Montana (Aderhold 1995, Heidel 1995, 1996a,b). In 1996 it was first discovered in Idaho (Moseley 1996) and Nebraska (Hazlett 1996). In 1997 it was discovered in Washington (Sheviak, Gamon pers. commun.). It is now known from seven states and the historic record in Nevada. Figure 3 is a rangewide distribution map by Ronald Hartman (University of Wyoming), differentiating between occurrences documented prior vs. subsequent to the time that it was federally designated. The distribution is highly discontinuous between the dots, and the species is sparsely distributed throughout its range.

\section{B. Precise occurrences.}

\section{Populations currently known to be extant.}

a. Montana: The distribution of Ute ladies'-tresses has been circumscribed in Montana, where it is known from ten element occurrences in four counties in intermontane valleys centered on the Jefferson River, and confluent lower reaches of the Gallatin, Madison, Beaverhead and Ruby rivers (Figure 4). They represent app. 80 miles of connected intermontane valleys in the headwaters of the Missouri River. It is highly restricted to a tiny microhabitat within meandered wetlands within four restricted soil series. The occurrences are represented in Table 1 and in occurrence printouts (Appendix 1.)

Table 2. Spiranthes diluvialis locations in Montana

\begin{tabular}{|l|l|l|l|}
\hline $\begin{array}{l}\text { Element } \\
\text { Occur. No. }\end{array}$ & County & River Valley & $\begin{array}{l}\text { Township } \\
\text { and Range }\end{array}$ \\
\hline 001 & Jefferson & Jefferson & T.1N R.4W \\
\hline 002 & Madison & Beaverhead & T.5S R.7W \\
\hline 004 & Madison & Beaverhead & T.4S R.6W \\
\hline 005 & Jefferson & Jefferson & T.1N R.4W \\
\hline 006 & Madison & Ruby & T.6S R.4W \\
\hline 007 & Madison & Jefferson & T.1S R.5W \\
\hline 008 & Gallatin & Gallatin & T.2N R.4E \\
\hline 009 & Gallatin & Jefferson & T.2N R.1E \\
\hline 010 & Gallatin & Madison & T.2N R.2E \\
\hline 011 & Beaverhead & Beaverhead & T.6S R.8 \\
\hline
\end{tabular}


Initially, it was only known from the one site in the Jefferson River valley (Heidel 1995). Subsequent surveys within app. 40 contiguous miles of the Jefferson and Beaverhead River valleys were conducted in 1996 using black and white aerial photographs of the Montana Department of Natural Resources and the Farm Service Agency and search images from the single known site to produce the interim status report (Heidel 1997). A priority was placed on surveying public lands with potential habitat, conducted under land use license No. 8102 of the Montana Department of Natural Resources.

Surveys were expanded in 1997 using three effective search criteria. First, a greatly-expanded aerial photointerpretation was conducted in 1997 among discrete areas of eight counties (Beaverhead, Broadwater, Deerlodge, Gallatin, Granite, Jefferson, Madison and Silverbow counties) that have broad, arid valley-bottoms with a Great Basin flora and meandered wetlands. Black and white aerial photographs $\left(8^{\prime \prime}=1\right.$ mile) were examined in the Farm Service Agency Offices in Bozeman, Dillon, Deerlodge, and Whitehall. Xeroxes of the photographs, representing almost 300 sections, were made for consideration in groundtruthing and field evaluation. The meandered wetlands are readily discerned on aerial photographs, but microhabitat features corresponding with local species distribution can only be identified on the ground. Second, available published soils maps were available in Broadwater, Madison and parts of Silverbow counties to look for areas with the two associated soil series in which all Montana occurrences have been found. Note: The aerial photos that accompany the Broadwater soils mapping (Olsen et al. 1977) were used in place of Farm Service Agency photographs for that county. Third, the southwestern Montana collection records of two closelyassociated species were also used as leads to potential habitat in these counties.

In addition, a single riparian corridor survey was conducted along app. 20 miles of the Jefferson River in the center of its overall distribution but beyond the bounds of the other search criteria. The species was sought unsuccessfully in the successional habitat which harbors it in other states, i.e., river shoreline, sandbar meadows and swales, seasonally-linked oxbows, and temporarily-inundated benches. The Jefferson River corridor vegetation and flat landscape setting did not resemble the places where the species was found in other states. Only one shoreline segment offered the same vegetation and soil conditions that resembled the other places where it is found in Montana, but the site was degraded and unoccupied. 


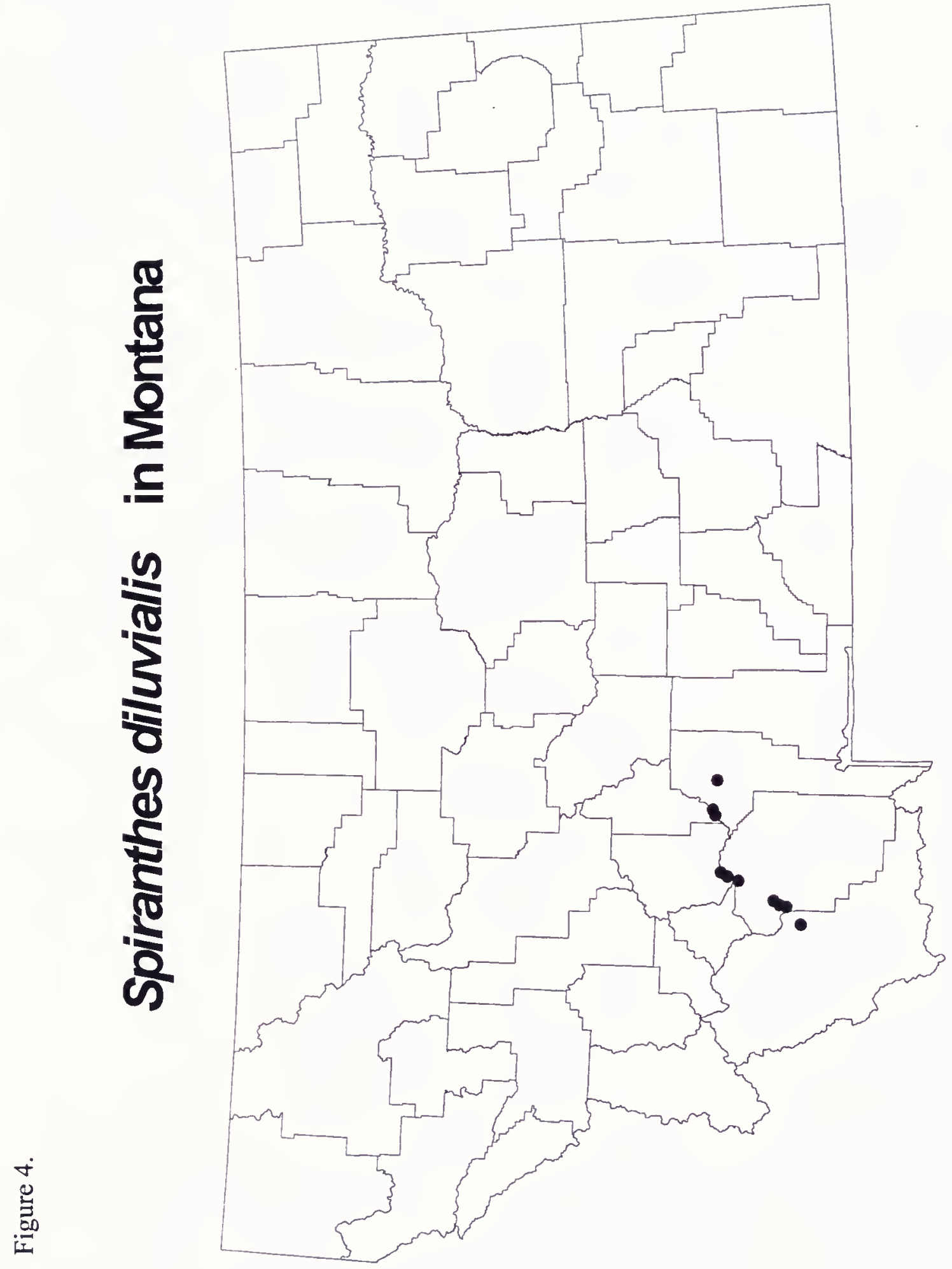


The ten occurrences may have historically represented five metapopulations. In any case, they represent five areas where the associated soil series occurs. They are all greater than 2 miles from one another and do not have continuous habitat, so they are treated as separate occurrences.

\section{Populations known or assumed extirpated.}

a. Montana: None.

3. Historically known populations where current status is not known:

a. Montana: Not applicable.

4. Locations not yet investigated believed likely to support additional natural populations. This report represents the results of systematic survey across eight counties; roughly circumscribing species' distribution in western Montana, doubling the number of occurrences since the interim report (Heidel 1997), adding two new counties of distribution, and diminishing the likelihood of occurrences in other western Montana counties and along other rivers. Landscapes in southwestern Montana with meandered wetland complexes, the four soils series, and collection records of the associated species have been evaluated to determine presence/absence. Compilation of soils information is needed to critique completeness. Nor is the search for occurrences within each setting to be considered exhaustive due to access and time constraints, but the distribution is demarcated. The upstream extent of the species on the Ruby River above Alder was treated in incomplete surveys, the upstream extent on the Beaverhead River immediately upstream from Dillon was not investigated, nor were all associated species collection sites in southern Beaverhead County evaluated (i.e., Primula incana in the wellstudied settings of Carex parryana ssp. idahoa.)

There have been no surveys for it in eastern Montana. There is inadequate background information for determining the appropriateness of such investigation. It has been collected in the Great Plains of southeastern Wyoming in a watershed that does not extend into Montana. There is one Spiranthes specimen from Sheridan County in the extreme northeastern corner of Montana that represents a range extension for the Spiranthes genus in Montana. Though it is unlikely to be $S$. diluvialis, it deserves special mention. It was collected in 1923 and deposited at the Missouri Botanical Gardens (Sheviak pers. commun.). The material is not useable for definitive identification, and there are no other known collections of ladies'-tresses from eastern Montana, though both parent species are extant in highly restricted peatland settings of North Dakota to the east. 
5. Reports having ambiguous or incomplete locality information:

a. Montana: None. Herbaria in the state, including MONTU and MONT, have been searched for specimens of Spiranthes diluvialis which might be misidentified as $S$. romanzoffiana, and none were found.

\section{Locations known or suspected to be erroneous reports:}

a. Montana: None.

C. Biogeographical and phylogenetic history: Spiranthes diluvialis is intermediate between its putative parent species, hooded ladies'-tresses (S. romanzoffiana) and Great Plains ladies'-tresses (S. magnicamporum). It is an allotetraploid $(2 \mathrm{n}=74$; Sheviak 1984) which possesses a combination of alleles found within the putative diploid parent species (S. romanzoffiana $2 \mathrm{n}=44$ and $S$. magnicamporum $2 \mathrm{n}=30$; Sheviak 1984). It hypothesized to have evolved when the two parent species were sympatric or parapatric during a relatively cool, wet Pleistocene pluvial period (Sheviak 1984). These climatic conditions may have shifted the overall distribution of $S$. romanzoffiana relatively low in its elevation range on the Rocky Mountains, and the distribution of $S$. magnicamporum relatively far west across what are the driest segments of the Great Plains, bringing the distribution of the two species into overlap or proximity.

Genetic research on Spiranthes dilvialis in Colorado and Utah indicates that it evolved from at least two separate hybridization events (Arft 1995a). The Montana populations in the headwaters of the Missouri River may have a separate origin from those in the rest of its range. Genetic analysis of the species at the northern and eastern ends of its range are proposed for conservation planning purposes.

\section{General environment and habitat description.}

A. Concise statement of general environment and habitat: Spiranthes diluvialis is restricted to a small, sporadic microhabitat represented by calcareous, wet-mesic, temporarily-inundated meadow in shallow wetlands. The shallow meandered wetlands are in alluvial fans (Boast \& Shelito 1989) that correspond with two uncommon soils series. They are part of broad, flat, arid, open, low-elevation valley bottoms. The meandered wetlands include narrow channels and broader swales, both of which parallel the existing river courses, and most are set back over a mile from the river and without surface-water connections to the river. The valley crosssections where it occurs are depicted in Figure 5. 
Figure 5.

Spiranthes diluvialis

Landscape Setting in Montana

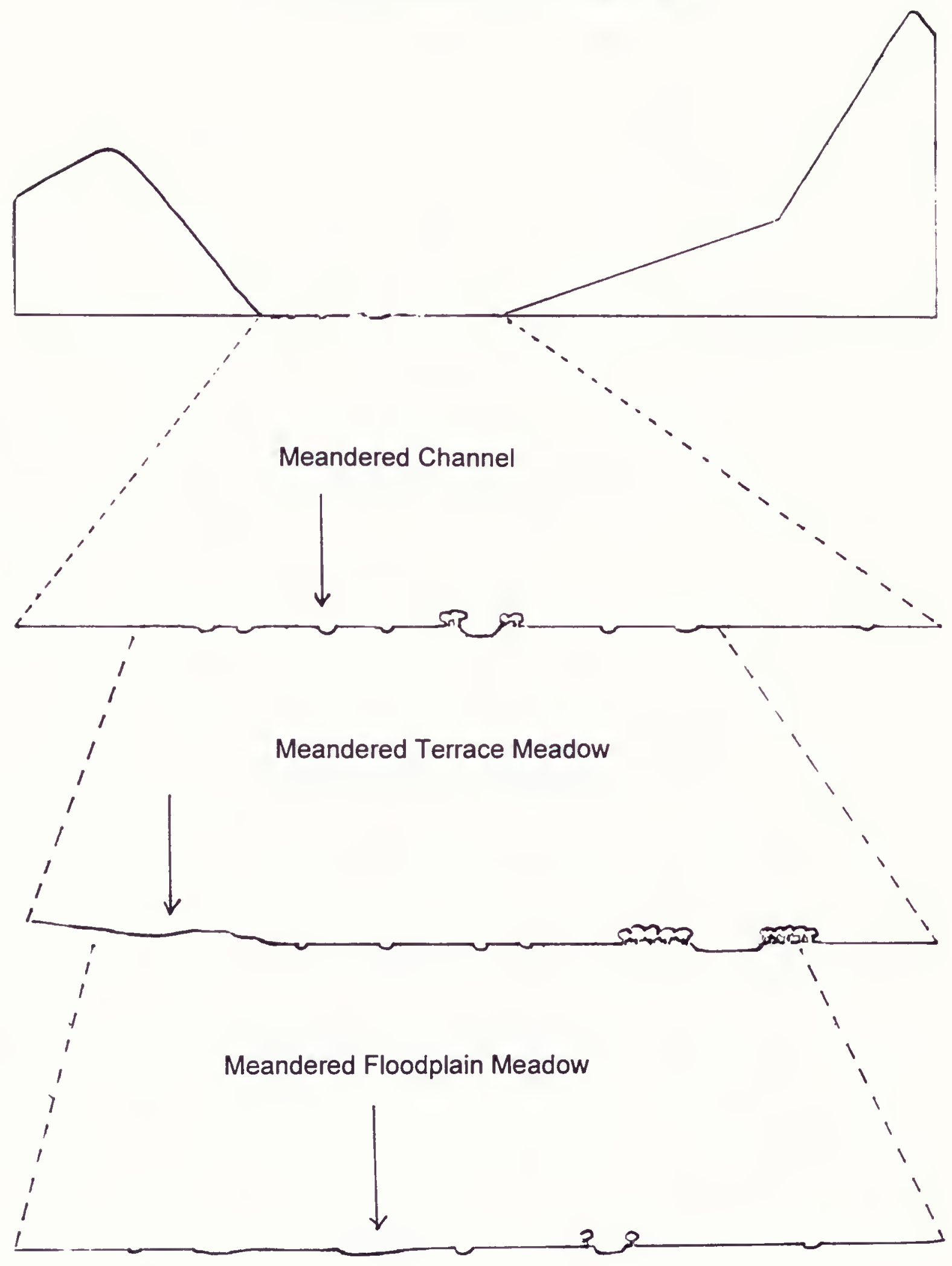

-1 mile - 
B. Physical characteristics.

1. Climate.

a. Koppen climate classification: Type Dfb, with average January temperature below $0^{\circ} \mathrm{C}\left(32^{\circ} \mathrm{F}\right)$, average temperature of the warmest month above $10^{\circ}$ degrees $\mathrm{C}\left(50^{\circ} \mathrm{F}\right)$ and under $22^{\circ} \mathrm{C}\left(71.6^{\circ} \mathrm{F}\right)$, with no dry season, and the driest month of summer receives more than 3 $\mathrm{cm}$ (1.2 in.) of rain (Visher, 1954).

b. Regional microclimate: The closest climatological station located within the range of Spiranthes diluvialis is in Dillon. Data for the periods 1951-80 and 1961-90 are provided by the U.S. Department of Commerce (NOAA 1982, 1992). At the Dillon Airport (elevation $5,216 \mathrm{ft})$, the mean annual temperature is $13.4^{\circ} \mathrm{C}\left(56.1^{\circ} \mathrm{F}\right)$ and the highest mean monthly temperatures are in July at $27.9^{\circ} \mathrm{C}\left(82.7^{\circ} \mathrm{F}\right)$. The annual normal precipitation is $23.8 \mathrm{~cm}$ (9.53 inches). Most precipitation falls in May and June. Unlike the regional climate characterization, there is a distinct dry season with hot temperatures.

Climate regimes in Spiranthes diluvialis settings over the past four years have varied considerably from late season drought in 1994, to season-long coolness and wetness in 1997 that prevented some local landowners from getting a mature grain crop in nearby fields.

c. Local microclimate: Soils at Spiranthes diluvialis sites remain moist through the summer in the shallow wetland settings. Almost all occurrences are in full sun. The patchy, intermittent shrubs along the border provide negligible shade. The growing season diurnal temperature extremes are at their peak when the plant is flowering.

2. Air and water quality requirements: The microhabitat is temporarily inundated in spring, often located right below the outer wetland margin. Susbsurface hydrological conditions are ameliorated by high organic content at the surface, and coarse alluvial cobble directly below. Water chemistry as inferred from soils data is moderately alkaline and high in calcium carbonate.

3. Physiographic province: The Montana occurrences are within the Northern Rockies physiographic region that encompasses western Montana, as mapped by Fenneman (1931).

4. Physiographic and topographic characteristics: The species is in broad, open intermontane valleys that represent Cenozoic Basins with late Quaternary alluvium in southwestern Montana. The valleys are flat and the 
rivers have low gradient in these settings though they are fed by mountain tributaries. The $130 \mathrm{~km}$ (80 mile) length of valleys supporting the species have elevation ranges from 1224-1485 m (4080-4950 ft). The valleys are app. $5-8 \mathrm{~km}$ (3-5 miles) wide, with nearly-level floodplains across much of the valley width. Intermittent segments contain alkaline flats having wetland soils. In these flats it is restricted to meandered wetland channels and meadow-filled swales that represent alluvial fans. In the meandered wetlands, it is restricted to discrete bands in segments and zones with seeps or at least subsurface moisture through the summer. The wetland complexes are referred to as "alluvial fans" (Boast and Shelito 1989) and they are in areas that appear to have structural/tectonic interference (Locke pers. comm.), schematically presented by Reichmuth (1986).

Abandoned meandered wetlands represent one of two floodplain settings for the species in the rest of its range, the other being successional river corridor banks and backwaters (Jennings 1989, U.S. Fish \& Wildlife Service 1992.)

5. Edaphic factors: Soils are loamy calcareous wetland soils, with gley features.

Orchid ecology is often closely linked with edaphic factors and mycorrhizal fungi (Wells 1981), so this study included collection of soils data to refine the habitat description. Edaphic conditions were documented by collecting soil samples at five of the sites that represent the array of habitats and includes the three largest populations in Montana. There was no replicate sampling but multiple samples were taken at two sites where Spiranthes diluvialis occupied different microhabitats. Soils were collected during the August flowering period to a depth of $10 \mathrm{~cm}$, air-dried and color was recorded using the Munsell color chart. Analysis of texture, $\mathrm{pH}$ (buffered 7.0), organic matter $(\%)$, conductivity $(\mathrm{mmhos} / \mathrm{cm})$, cation exchange capacity $(\mathrm{cmol} / \mathrm{kg})$, and nutrients in ppm (ammonia, nitrate, excess lime, potassium, Bray phosphorus, zinc, iron, manganese, copper, sodium) were conducted by the University of Nebraska Soils Testing Service in conjunction with soil sample tests collected from Spiranthes diluvialis sites in Nebraska and Wyoming. Results were compared with soils sample results previously compiled from Spiranthes diluvialis sites in Colorado and Utah (Arft 1995a). Results are summarized in Table 2 as reprinted from the report by Hildebrand (1998), and the raw data for Montana sites is included in Appendix F.

Soils at Spiranthes diluvialis sites in general are high in micronutrients and organic matter, but are low in phosphorus compared to average values for agricultural soils. The Montana soils generally overlap with the Nebraska and Wyoming soils in having high potassium concentrations, and low zinc, copper, and ammonia concentrations relative to the Colorado and Utah sites. 
Table 3. Comparison of soil parameters at Spiranthes diluvialis sites

\begin{tabular}{|l|l|l|l|}
\hline $\begin{array}{l}\text { SOIL } \\
\text { PARAMETER }\end{array}$ & $\begin{array}{l}\text { AVERAGE } \\
\text { VALUES FOR } \\
\text { AGRICULTUR. } \\
\text { SOILS }\end{array}$ & $\begin{array}{l}\text { RANGE OF } \\
\text { VALUES at sites } \\
\text { in CO\&UT (Arft } \\
1995 \mathrm{a})\end{array}$ & $\begin{array}{l}\text { RANGE OF } \\
\text { VALUES AND } \\
\text { MEAN at sites in } \\
\text { NE, WY \& MT } \\
\text { (Hildebrand 1998) }\end{array}$ \\
\hline $\mathrm{pH}$ & & $6.6-8.15$ & $7.66-8.25(7.88)$ \\
\hline K ppm & $60-120$ & $65-160$ & $102-586(292.53)$ \\
\hline Bray P ppm & $4.0-7.0$ & $1-3.4$ & $0-2.61(1.24)$ \\
\hline$\%$ Organic Matter & 2.5 & $7.0-16$ & $2.24-26.35(9.92)$ \\
\hline ZN DTPA ppm & $0-0.2$ & $3.0-270$ & $0.48-4.03(2.66)$ \\
\hline MN DTPA ppm & $0-0.5$ & $8.0-26$ & $6.3-63(27.76)$ \\
\hline FE DTPA ppm & $0-5$ & $60-280$ & $\begin{array}{l}40.4-281.3 \\
(110.35)\end{array}$ \\
\hline CU DTPA ppm & $0-0.2$ & $11.0-56.0$ & $0.48-5.2(1.52)$ \\
\hline $\begin{array}{l}\text { Conductivity } \\
\text { mmhos/cm }\end{array}$ & $0-2$ & $0.37-1.9$ & $0.3-1.5(0.72)$ \\
\hline Ammonia ppm & & $6.5-12.8$ & $2.81-6.4(4.26)$ \\
\hline Nitrate ppm & $19-36$ & $2.0-29$ & $1.94-5.53(3.44)$ \\
\hline
\end{tabular}

Soils at the Montana sites are typically light in color, chrome and hue (most are $2.5 \mathrm{Y} 6 / 2$ ), moderately alkaline ( $\mathrm{pH} 7.6-8.07$ ), and are all loamy (loam, sandy loam, or silt loam) with exception of one exceptionally well-developed marl deposit area (part of EO\#004). It may have had so much soluble calcium carbonate accumulation ("bog lime") that there was too little sediment to place it in a textural class. Sand otherwise makes up the majority of the sediment in all samples except in one sample classified as a silt loam (EO\#005). The marl sample and two other soil samples have $20 \%$ or more organic content which is comparable to productive farmlands but which, if composed of undecayed material, potentially classifies them as peat or histosols. Coarse alluvial cobble was found below the soil horizon at each of the five sites. In some cases the soil profile was thinner than the $10 \mathrm{~cm}$ depth of the soil sample above the loose cobble, in which case the loose, smoothlyrounded cobbles were excluded from textural classification. 
The Jefferson County sites have substrates developed from late Quaternary alluvium (Kuenzi and Fields 1971). The particular landscape segments that have the wetland inclusions which provide habitat for Spiranthes diluvialis are mapped as the Neen or Villy soil series among the seven western occurrences (Beaverhead, Jefferson and Madison counties) and as the Fairway-Threeriver-Rivra complex or the Saypo series among the three eastern occurrences in Gallatin County. Note: The soil series of actual wetland microhabitats has not been determined, and the following discussion pertains to the terrain surrounding meandered wetlands.

Neen soils are fine silty mixed frigid Aquic Calciorthids, Villy soils are fine silty mixed (calcareous) frigid Typic Fluvaquents, and Fairway soils are fine, laomy mixed Fluvaquentic Haploborolls. They are classified as wetland soils. The meandered wetlands are just inclusions that are not mapped separately. The distribution of at least the first these two of the soils series corresponds with the distribution of alluvial fans laced by meandered wetlands (Boast and Shelito 1989). It appears that soils mapping can be used with efficiency and possibly accuracy exceeding that of aerial photointerpretation for pinpointing areas with the microhabitat features that signify potential habitat. These first two soil series make up small fractions of the land area in Madison County (totaling $1.2 \%$ and $0.3 \%$, respectively) and are surrounded by other soil series that represent aridisols and mollisols.

The soil series that make up the landscapes surrounding the Spiranthes diluvialis habitat are all characterized in soil classifications as high in calcium carbonate and "salt-affected" within the rooting zone. They are also all classified as "subirrigated" range sites.

Soil temperature was measured at the five sites $(1 \mathrm{~cm}$. Depth) at places where soil samples were collected in August. These were compared to air temperature readings to investigate the groundwater source. Soil temperatures ranged from 15.0-20.8 degrees Celsius; not appreciably different from the mean August air temperatures. It is inferred that deep water sources would have constantly cold water temperatures (unless connected to thermal features). The moderate soil temperature readings, presence of very coarse unconsolidated alluvial cobble underlying the soil profiles, and likelihood of accompanying impervious lenses in alluvial deposits supports the idea that the groundwater draws from shallow rather than deep aquifers.

6. Dependence of this taxon on natural disturbance: This species has been characterized as a colonizer of early successional riparian habitat; persisting in those areas where successional conditions are perpetuated or competition is constrained in some way (U.S. Fish and Wildlife Service 1995b.) In keeping with this riverine habitat model of scouring and deposition, the 
continued changes in stream channel position and encroachment of latersuccessional vegetation may eventually result in a localized decline. But not all occurrences are confined to riversides. It is also found in valley meadows where agricultural practices (grazing and haying) reduce competition under some conditions by an appropriately-timed removal of competing vegetation (Arft 1995a).

In the cases of the Montana occurrences, its habitat is not directly associated with riverside succession. Instead, they are along shallow, wetlands set back from the rivers in broad, open valleys. They are highly meandered shallow wetland complexes and they are part of alluvial fans possibly attributed to structural/tectonic activity (Locke pers. commun.).

In Montana, it appears restricted to localized edaphic conditions rather than seral stages in order to compete with other vegetation and persist. It was most consistently found in small zones and meander segments where calcium carbonate and possibly peat concentrations are high. The density and stature of the vegetation in these locales was usually sparse and short compared to surrounding wetland habitat. These meadow settings are analgous to those of meadow occurrences in other states.

The Montana sites are in a landscape that was historically grazed by bison and periodically burned by Native Americans. Abundant buffalo sign were noted in what is now the Whitehall area, and recent fires set by Indians noted both upstream and downstream by Lewis and Clark (Nell and Taylor 1996). In the areas where Spiranthes diluvialis occurs, Lewis reported traversing the high bordering plains rather than the "wide bottoms" because of the "meriads of deep holes" where they also noted "mineral salts" and "some excellent terf or peat" (Nell and Taylor 1996).

Wildfire burned throughout one segment of a population (EO\#004) that was also the only observed species' setting with extensive pools of standing water. The fire was concentrated in the surrounding upland. It is believed to correspond with newspaper reports of lightening-started fire in the droughtconditions of 1994. The fire charred the few willows in the middle of the wetland habitat, most of which resprouted. This suggests that fire can burn the wetland meadow habitat and that the species survives fire under some circumstances, but it is inadequate circumstantial information lacking in details and controls for making any other inferences.

7. Other unusual physical features: The meandered wetland channels are highly convoluted and found in parallel series, sometimes in high density. The Spiranthes diluvialis is found in discontinuous bands on either side of the wetland margin. There can be several miles of potential habitat within a given 
section, but the suitable microhabitat is magnitudes less extensive. A tracing of the wetlands in a high-density section is provided in Figure 6 . The origin of these extensive wetland systems has not been studied.

\section{Biological characteristics.}

I. Vegetation physiognomy and community structure: All Montana occurrences are within broad, open or semi-open intermontane valleybottoms with grassland. In these settings, the occurrences are restricted to discrete zones sporadically distributed along abandoned meandered wetlands. Most occurrences are in broken bands along the outer margins of wetland channels and a couple are also across the bottom of wet meadow swales. The occupied habitat within these shallow wetland settings have emergent vegetation of relatively sparse cover and short stature compared to other wetland vegetation in the wetland meanders.

2. Regional vegetation types: There is no published mapping of the potential natural vegetation of intermontane valleys in Montana at a scale finer than the Kuchler map (1964). This map shows Intermountain shrub-steppe grassland across the foothills and valleys without a discrete valleybottom vegetation in the ancient floodplains.

Landscapes containing Spiranthes diluvialis are small vegetation inclusions in the undescribed valleybottom matrix, i.e. patches within the larger open grasslands. The patches are dominated by the alkali sacaton plant association (Sporobolus airoides p.a.). Buffaloberry (Shepherdia argentea) contributes more than trace coverage, particularly along the edge of the meandered wetlands. Robbins milkvetch (Astragalus robbinsii) is common in alkali sacaton uplands, and is often locally abundant at the wetland edges. Cottonwoods (Populus spp.) and willows (Salix spp.) are intermittent or absent on-site, though they are found along the nearby river banks. Water birch (Betula occidentalis) is occasionally present in or near the same settings as Spiranthes diluvialis. The Gallatin County upland vegetation has western wheatgrass (Elymus smithii; syn. Agropyron smithii) as codominant with alkali sacaton, and a discrete association apparently dominanted by Muhlenbergia racemosa is also present. Halophytic vegetation types are sometimes present in the nearby landscape, including the Sarcobatus vermiculatus p.a.

Alkali sacaton p.a. is the surrounding upland vegetation at Montana's Spiranthes diluvialis sites. This is different from associated upland vegetation in the rest of its range, though many of the associated wetland species are similar. Halophytic species also are present at Spiranthes diluvialis sites of Nebraska (Hildebrand 1998) and Washington (Gamon pers. commun.) . 
Figure 6. Meandered wetland complexes of a representative section with potential Spiranthes diluvialis habitat

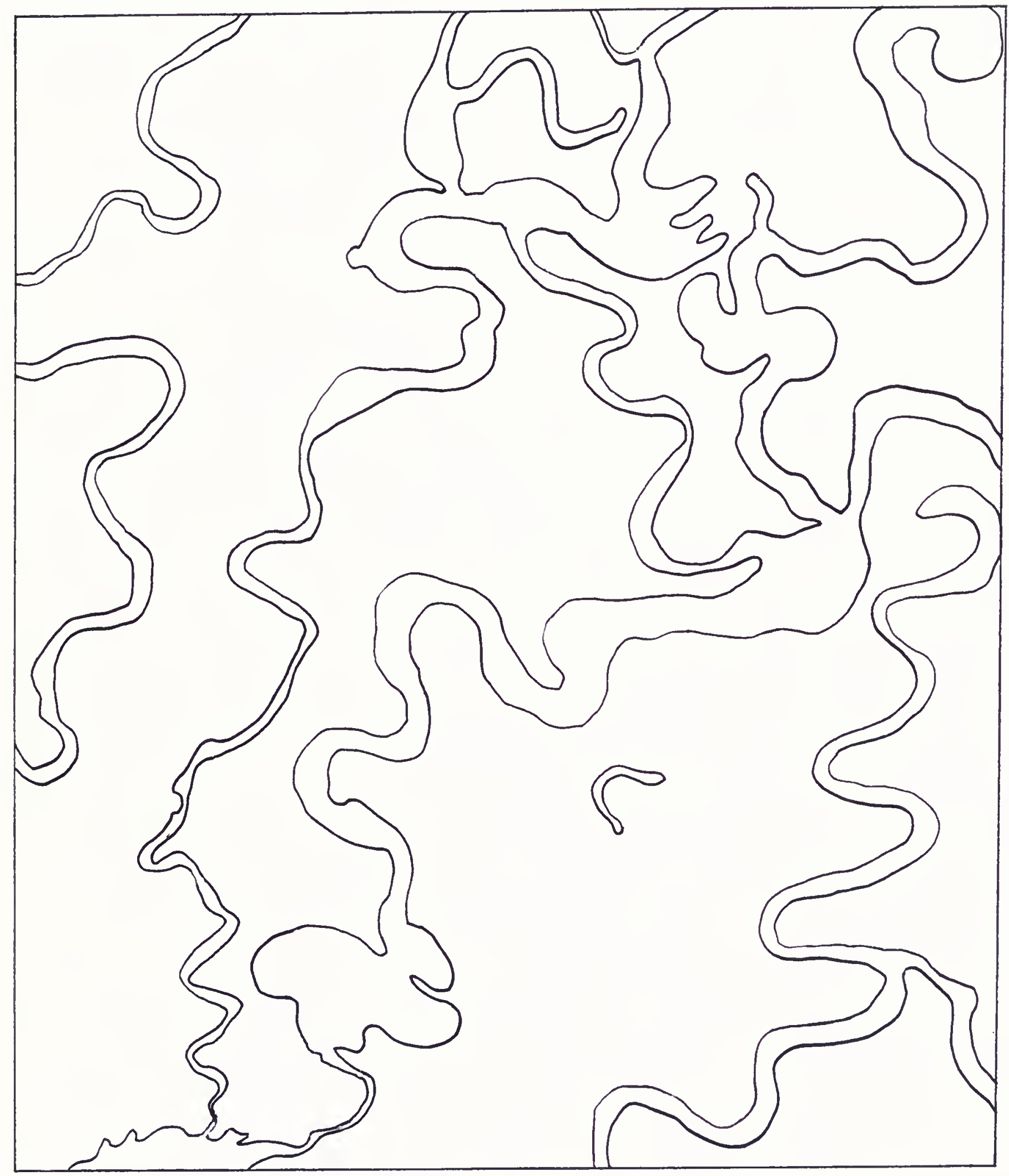


though the associations differ. By contrast, the nearest out-of-state sites in Idaho they have steep canyon conifer communities and cottonwoods lining the riparian corridor where the species occurs.

3. Frequently associated species: In the immediate vicinity of Spiranthes diluvialis, the graminoid vegetation is often markedly short in height (less than $20 \mathrm{~cm}$ ) and with less than complete canopy cover (40-80\%) exposing more bare soil or litter compared to the surrounding wetland plant associations. The local dominants and abundant species vary between sites, but the species at Montana sites with cover of $10 \%$ or greater, include: Agrostis stolonifera, Carex simulata, Eleocharis pauciflora, Elymus trachycaulus, Juncus balticus, Muhlenbergia asperifolia, Muhlenbergia filiformis, and Juncus longistylis.

Carex simulata distribution has the highest correlation with Spiranthes diluvialis distribution within the study area. The relatively widespread exotic species, Agrostis stolonifera, was also found with high consistency at Spiranthes diluvialis occurrences. The plant associations dominated by Carex simulata and Eleocharis pauciflora were at the short and sparse extreme in vegetation structure. Juncus balticus is ubiquitous and other species of rush are locally common compared to surrounding wetlands. Other species that tend to be highly localized and associated with Spiranthes diluvialis at two or more of the documented sites include: Castillej exilis, Primula incana, Triglochin maritima, Sphenopholis obtusata, Habenaria hyperborea, and Phlox kelseyi var. kelseyi.

At one extreme, it occurred in a relatively well-developed peatland setting that included Triglochin palustre, Aster junciformis, and Salix candida amid pools of Chara spp. (in one segment of EO\#004; the aforementioned burn site). At the other extreme, it was in associations made up of relatively widespread graminoids like Elymus trachycalus, Carex praegracilis and Calamagrostis inexpansa (EO\#001) as a wetland band that is preferentially grazed to short heights early in the growing season.

Five sites were sampled in $1 \times 1 \mathrm{~m}$ areas of relatively Spiranthes diluvialis density to refine the vegetation description. The microplots appeared to represent more extensive, repeating plant associations but were not expanded because of the microhabitat discontinuity. In addition, two sites had two samples representing two different associations, for a total of seven microplots. Finally, a pair of microplots were sampled directly above and below a Spiranthes diluvialis plot to profile the major shifts in wetland vegetation composition over the short distance of three contiguous meters of the moisture gradient (Figure 7). Canopy cover was estimated in 10\% increment categories for all vascular species within the area, and soil surface 
cover was also estimated. The cover synthesis table for the plots is presented in Appendix G. Plant assemblages recorded in the seven 1x1 $\mathrm{m}$ sampling plots, from most to least common, are listed below:

Carex simulata p.a.

Agrostis stolonifera c.t. and intergradations with the above

Juncus balticus c.t. and intergradations with the above

Eleocharis pauciflora. p.a.

Plant associations of Carex simulata and Eleocharis pauciflora as documented in Montana are not reported even in trace amounts at Spiranthes diluvialis sites in other states. These communities have not been reported in Montana apart from montane settings (Hansen et al. 1995) and thermal areas (Lesica 1990). At the nearest out-of-state sites in Idaho, the dominants are silverbery/redtop c.t. (Eleagnus commutat/Agrostis stolonifera cover type; Moseley, pers. commun.).

Species that have a high constancy at Spiranthes diluvialis sites across its range, not just in Montana, include: Agrostis stolonifera, Juncus balticus, Juncus longistylis, Equisetum laevigatum, and Habenaria hyperborea. A master list of the species associated with Spiranthes diluvialis across its range is compiled in Appendix $\mathrm{C}$ following the nomenclatural conventions of Dorn (1984). This floristic compilation has inconsistencies between states in representing one to many sites, and in representing either the immediate plant association or including adjoining plant associations, yet it provides an initial basis for comparisons.

The surrounding wetland vegetation in the rest of the meandered wetlands is highly variable within and among the Montana sites. They are mainly temporarily and seasonally inundated emergent wetland communities, variously dominated by sedges including Carex aquatilis, C. praegracilis, and $C$. lanuginosa. These sedges are all recognized as widespread wetland dominants (Hansen et al. 1995). At adjoining wetland at the easternmost site in Gallatin County were species more typical of montane wetlands, including tufted hairgras (Deschampsia cespitosa) and Carex scirpiformis.

Mosses are present at all occurrences, but their cover on the soil surface varies considerably (trace $-50 \%$ ), probably varying with livestock use patterns and leaf litter accumulation. The three moss species noted to date at EO \#001 are calciphilic wetland species. Mosses were identified by Joe Elliott. This rudimentary associated moss flora at one site (\#001) included: Amblystegium serpens, Bryum capillare, and Campylium stellatum; two of the three overlap with the moss flora associated with the species in Nebraska (Hildebrand 1998). 
Figure 7. Vegetation gradient profiled through Spiranthes diluvialis habitat

2 AGRSTO

3 CARNEB

4 CARPAR

5 CARSIM

6 ELEPAR

7 ELYTRA

8 JUNBAL

9 JUNTOR

10 MUHFIL

11 SPHOBT

12 ASTERI

13 ASTROB

14 CASEXI

15 EQULAE

16 LYCASP

17 PARFIM

18 PLAERI

19 POTANS

20 SONASP

21 SPIDIL

22 TRIFRA

23 TRIMAR

24 TRIPAL
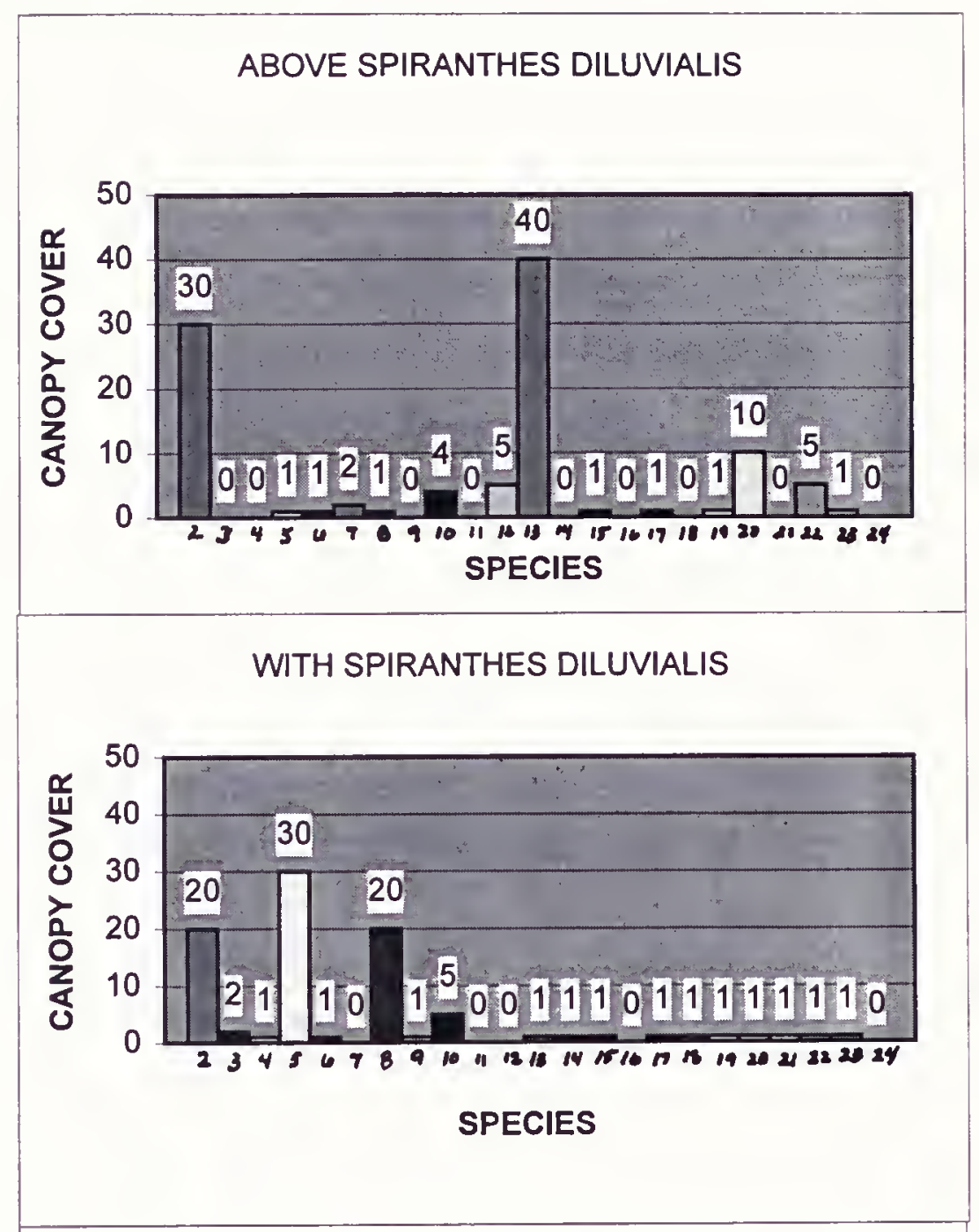

BELOW SPIRANTHES DILUVIALIS

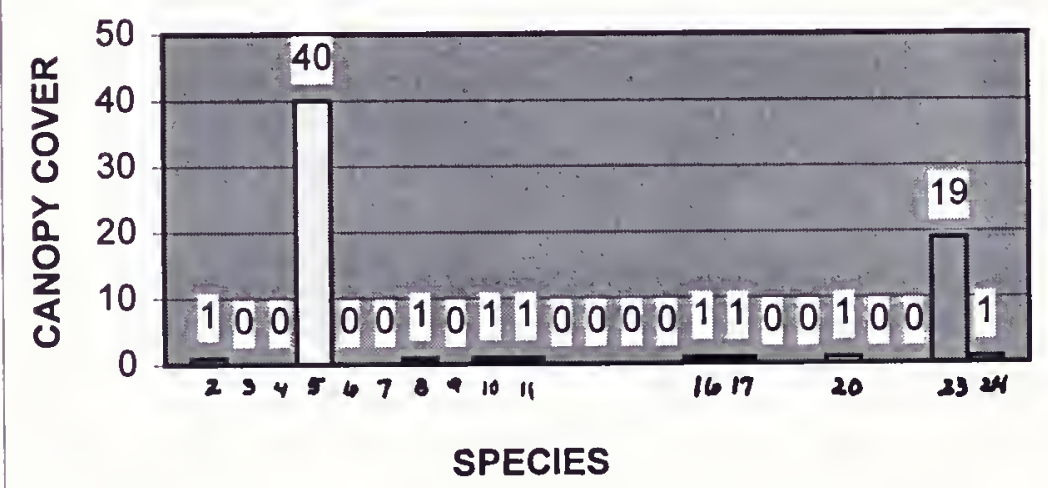


Presence and signs of sandhill crane, whitetail deer, and mallard were consistently noted, in the same river reaches where Lewis and Clark noted "crain", the transition from mule deer to "the fine venison" of "longtailed red deer", and meals of "duckanmalla\{r\}d (Nell and Taylor 1996).

4. Dominance and frequency of the taxon: Flowering stems of Spiranthes diluvialis are rare, uncommon or occasional in all Montana sites documented to date. Low densities and population numbers are typical for the species throughout its range with the exception of six large occurrences in Colorado, Utah and Nebraska (U.S. Fish and Wildlife Service, 1995b, Hazlett 1996).

5. Successional phenomena: Spiranthes diluvialis has been characterized as a riparian succession species (U.S. Fish and Wildlife Service 1995b). In Montana, with the exception of EO\#005 and EO\#006 it seems that Spiranthes diluvialis is restricted to stable settings with reduced competition as dictated by soils; early-season grazing further reduces the standing crop of competing vegetation. The only evidence of successional processes were in response to man-made changes. Part or all of the EO\#005 was inundated by irrigation ditch seepage in the past before the ditch was plugged (owner pers. commun.). All of EO\#006 is confined to an excavated road ditch.

The exotic species component may reflect the dynamic habitat if not a successional nature. Red-top (Agrostis stolonifera) is ubiquitous at Montana sites and possible throughout its range (Appendix B). The rest of the exotic species component varies widely between sites, including Canada thistle (Cirsium arvense), Kentucky bluegrass (Poa pratensis), clovers (Trifolium frageriferum, T. repens) and others. Elsewhere in the range are other exotic species (Appendix B). Noxious weeds are in the landscape at most of the sites and adjoin species' habitat at two of the ten sites. Leafy spurge (Euphorbia esula) is encroaching Spiranthes diluvialis habitat in EO\#004, Russian knapweed (Centaurea repens) is at wetland margins nearby in the same area, and spotted knapweed (Centaurea maculosa) is abundant along a travel corridor bordering EO\#001.

An unusual exotic flora has been also documented above these meandered wetlands. Sandspurry (Spergularia media) was documented in Montana for the first time from the same area where Spiranthes diluvialis was first documented. It is a halophyte that is native to coastlines of Europe, verified by J. Ratter, the Scottish expert in the genus. Montana and Wyoming have the only known inland locations of sandspurry in North America.

In addition, a sedge (Carex spp.) was documented by Peter Lesica from the same general area. It may represent an exotic species new to the continent 
according to A. Reznicek (Lesica pers. commun.); the determination is in progress. This same unknown species has been collected in the area of Spiranthes diluvialis in Gallatin and Madison counties as part of the study and submitted to Reznicek.

Finally, the exotic meadow fescue (Festuca elatior; Festuca arundinacea) was often found in wetland margin and meadow. It occurred sporadically as an adventive species rather than in abundance as a planted species.

6. Dependence on dynamic aspects of biotic associations and ecosystem features: The plants associations are made up of long-lived perennials, but their vigor and flowering activity from year-to-year are variable with climate and with livestock grazing. The wetland microhabitats are intrinsically dynamic with changes in water availability and aerobic/anaerobic conditions.

7. Other endangered, threatened, rare, or vulnerable species occurring in habitat of this taxon: Two peripheral Montana Species of Special Concern were often found in association with Spiranthes diluvialis in Montana: Castilleja exilis (annual paintbrush; G5 S2)), a Great Basin species, and Primula incana (mealy primrose; G4G5 S2), a boreal species. Relocation of collection sites for these two species was attempted as part of the survey, including historic records, representing a visit to most of the collection areas in southwestern Montana. The Castilleja exilis is present at the majority of the wetland sites for Spiranthes diluvialis, but it is not restricted to these wetland settings. Prior to Peter Lesica's collection of it in 1994, it was known only from four historic records, the most recent of which was 1906. This species has a broader ecological amplitude and geographic distribution than Spiranthes diluvialis in Montana. New county records or relocated historic records for it were documented as part of this study in Beaverhead, Broadwater, Deerlodge, Gallatin, Granite, Madison, and Silverbow counties, in addition to Jefferson County.

The Primula incana is a boreal species which is also present at the majority of Spiranthes diluvialis occurrences, corresponding with the sites having the greates amount of calcium carbonate deposition. It has a broader distribution in Montana than Spiranthes diluvialis, but it is more restricted in its habitat to soils that remain saturated throughout the growing season, and which are consistently high in calcium carbonate. New county records or relocated historic records for it were documented as part of this study in Beaverhead, Broadwater, Deer Lodge, Gallatin, and Silverbow counties, in addition to Jefferson County.

In addition, Eleocharis rostellata (beaked spikerush; G5 S2) has been identified in the vicinity of Spiranthes diluvialis occurrences, and is suspected 
but unconfirmed at one of them (EO\#004). It is an associated species that is locally dominant at one of the Idaho occurrences.

\section{Population biology of the taxon.}

A. General summary: Spiranthes diluvialis is an herbaceous perennial that is longlived and has fluctuations in flowering stem numbers from year to year; primarily due to the shift between flowering and non-flowering states (Arft 1995a). Most of the non-flowering plants are in vegetative condition represented by basal leaves, but they also persist underground in season-long dormancy (Arft 1995a, Riedel, in litt., 1993), as has been documented for other species of plants including orchids (Tamm 1972, reviewed in Lesica and Steele 1994). The season-long dormancy state is actually a mycotrophic state dependent on endocycorrhize (e.g. Gill 1996, in Allen 1996). Efforts to propagate Spiranthes diluvialis are underway by Denver Botanic Gardens and the Red Butte Gardens of Salt Lake City, which will help elucidate early stages of life history.

Monthly data collected in a Colorado population indicated that Spiranthes diluvialis usually produced an overwintering rosette during late summer or fall (Arft 1995b). Leaf growth occurred during the growing season following rosette formation. Inflorescence buds were produced as early as June, followed by flowers from midJuly to mid-August (at least two weeks earlier than in Montana). Fruits matured and dehisced from mid-August into September. Mature vegetative plants average between $10-15 \mathrm{~cm}$ in height. Mature plants may remain dormant for at least one growing season without producing any above-ground shoot, but the vegetative shoot condition was much more common than the dormant condition overall for populations monitored in Colorado and Utah (Arft 1995a). Studies of Spiranthes magnicamporum in western Kansas and Nebraska report that the incidence of orchid flowering may be as infrequent as once in 20 years (Magrath 1973 in U.S. Fish and Wildlife Service 1995b). Studies of Cypripedium acaule energy allocation document that flowering represents up to $18 \%$ of the plant dry weight, reducing the probability of flowering the following year. A similar pattern is suggested for Spiranthes diluvialis as supported by preliminary monitoring results in which only $30 \%$ of the plants flowering in 1996 flowered in 1997 (Appendix D). Species' longevity has not been determined.

\section{B. Demography.}

1. Known populations: The most important demographic parameters in longlived perennials, as identified in conservation of Spiranthes spiralis, are recruitment, mortality, survivorship, longevity and turn-over (Wells 1981). Preliminary population projections have been made for Spiranthes diluvialis at Colorado and Utah occurrences with information to suggest that the "life history bottleneck" may vary depending on the land management practice 
(Arft 1995a). Much more work is needed to quantify these variables in the Colorado and Utah sites, or apply them in the rest of its range.

The ten known occurrences of Spiranthes diluvialis in Montana total over 1,400 flowering plants observed. Survey of plant numbers was incomplete or non-existent at two sites due to access restrictions but was comprehensive at small sites. The numbers of flowering plants in the two largest populations had a tally of over 500 plants in 1997, a favorable year for high flowering levels. Only one plant could be found in the smallest population.

These one-time counts are hampered by three factors, so that flowering stem counts are to be taken as very conservative low estimates of population size. First, mature plants may be in three alternate states, only one of which is easily located. These are the flowering state, the vegetative state with basal leaves and the seasonal dormancy state. The vegetative basal leaves are shorter than the canopy of grasses, and the narrow, linear leaves are difficult to discern among grass leaves (see photographs of plants as vegetative basal leaves in Appendix B). The dormancy state has no above-ground growth.

The transition between states has been shown to fluctuate significantly. At the City of Boulder site, flowering stem counts have varied from 5,435 stems in 1986 to 131 stems in 1998 (U.S. Fish \& Wildlife Service 1992). Subsequent monitoring has determined that the apparent decline is primarily attributable to the non-flowering state changes rather than mortality (Arft 1995a). Flowering stem counts were made at one Montana site (EO\#001) in four consecutive years, in a population estimated to have over 100 plants, but with annual flowering stem numbers ranging from 26-71 between years.

Second, the emergence of flowering shoots can be staggered by about four weeks, with some plants flowering in early August and fruiting by the end of the month, while a few plants are just beginning to flower in September (pers. obs. ). Even a count in peak flowering is apt to miss at least a trace of population numbers.

The third factor hinges on fieldwork resources. The species habitat cannot dependably be located without aerial photos to show the wetlands. It is difficult for an investigator to gaze across a seemingly level plain and pick out all of the channels less than $1 \mathrm{~m}$ deep snaking across it, particularly channels lacking shrub borders or having high density. The set of over 300 aerial photo xeroxes that were carried into the field proved to be incomplete, and four of the new occurrences were surveyed without benefit of aerials so the surveys are to be considered incomplete. 
2. General demographic details (Montana):

a. EO\#001

1. Area occupied by population: Less than 1 acre.

2. Estimated number of individuals: Over $100+$ plants have een noted in the course of two years of observation and two years of monitoring. Peak flowering stem count was 71 in 1994. The demographic monitoring was set up at this site in 1996 (Appendix D).

3. Density: Sparse. The entire population fits within an area that is app. $25 \times 35 \mathrm{~m}$.

4. Presence of dispersed seeds: Capsules were maturing at the time of monitoring but none had begun to dehisce (24 August 1996 and 4 September 1997). Undehisced capsules were observed in November of 1997.

5. Evidence of reproduction: NA

6. Evidence of population expansion or decline: None

b. $\mathrm{EO} \# 002$

1. Area occupied by population: Less than 1 acre.

2. Estimated number of individuals: Only 1 plant could be found in four hours of searching. There are likely to be other plants at least in nonflowering state, but this is the smallest of occurrences.

3. Density: NA

4. Presence of dispersed seeds: NA

5. Evidence of reproduction: NA

6. Evidence of population expansion or decline: The valleybottom condition reflects past habitat degradation.

c. EO\#003 - MERGED WITH EO\#004 AND DELETED AS SEPARATE RECORD

d. EO\#004

1. Area occupied by population: This area has high microhabitat diversity and the most extensive population by far. It spans four sections, though the extent of occupied habitat is probably less than 10 acres.

2. Estimated number of individuals: This area had $\mathbf{5 8}$ flowering plants in 1996 based on over seven miles of walking. Additional areas with about 30 plants were documented in 1997 . This is probably low relative to the total population numbers for any given year.

3. Density: Sparse. There are few places where more than ten 
plants can be found along channel bends.

4. Presence of dispersed seeds: NA

5. Evidence of reproduction: NA

6. Evidence of population expansion or decline: There is much late-season irrigation water flowing through the site. It is possible that this cold water or its influence on the water table affects flowering activity, if not population trend.

\section{e. EO\#005}

1. Area occupied by population: This area has high microhabitat diversity over a relatively small area, with plants in four topographically different settings, totaling app. 20 acres.

2. Estimated number of individuals: One segment of the population that was observed two years in a row had app. 60 flowering plants in 1996 and 115 flowering plants in 1997. This is the part of the basis for characterizing 1997 as a year of high flowering activity. With the benefit of aerial photos, this site was inventoried systematically in 1997 and three additional areas with plants were found with a total of $500+$ plants.

3. Density: The plants are very widely scattered in extremely low densities. Only one wetland segment of $100 \mathrm{~m}$ length had greater or equal than 10 plants.

4. Presence of dispersed seeds: NA

5. Evidence of reproduction: NA

6. Evidence of population expansion or decline: NA

f. $\quad$ EO\#006

1. Area occupied by population: Less than 1 acre in a narrow corridor.

2. Estimated number of individuals: The complete population count was 164 , rounded up to 180 to cover plants that may have been in differing phenological states.

3. Density: Sporadic

4. Presence of dispersed seeds: NA

5. Evidence of reproduction: NA

6. Evidence of population expansion or decline: NA

g. $\quad$ EO\#007

1. Area occupied by population: Unknown.

2. Estimated number of individuals: Undetermined because access was not obtained. Five plants could be seen from the road. 
3. Density: Unknown.

4. Presence of dispersed seeds: NA

5. Evidence of reproduction: NA

6. Evidence of population expansion or decline: NA

h. $\quad \mathrm{EO} \# 008$

1. Area occupied by population: Less than 1 acre of suitable habitat was found in cursory survey across a much larger area.

2. Estimated number of individuals: Only two plants found. Systematic survey with aerial photos is needed.

3. Density: Low

4. Presence of dispersed seeds: NA

5. Evidence of reproduction: NA

6. Evidence of population expansion or decline: NA

i. $\quad$ EO\#009

1. Area occupied by population: Less than 1 acre.

2. Estimated number of individuals: Actual count of 32 .

3. Density: Sparse.

4. Presence of dispersed seeds: NA

5. Evidence of reproduction: NA

6. Evidence of population expansion or decline: NA

j. $\quad$ EO\#010

1. Area occupied by population: Less than 1 acre.

2. Estimated number of individuals: Actual count of 15 .

3. Density: Sparse.

4. Presence of dispersed seeds: NA

5. Evidence of reproduction: NA

6. Evidence of population expansion or decline: NA

k. EO\#011

1. Area occupied by population: The population spans app. 20 acres but its full extent was not determined.

2. Estimated number of individuals: Actual count of 500+. This is the site most seriously in need of extended inventory with aerial photos, and additional access permission.

3. Density: Occasional-sparse.

4. Presence of dispersed seeds: NA

5. Evidence of reproduction: NA

6. Evidence of population expansion or decline: NA 


\section{Phenology.}

1. Patterns: Flowering begins in early August and usually peaks around the third week. It may persist into early September barring frost or drought. The onset of flowering in Montana is late relative to the rest of its range, with at least one exception in that Idaho populations are later. Idaho populations were just beginning to flower by mid August in 1997 when Montana populations were in peak flowering (pers. obs.).

Flowering has been found to vary significantly among individuals of an occurrence (EO\#001), with up to a four-week offset. In the early or late portions of the flowering period, there are some plants in peak flower while others are fully in bud or fully senesced, respectively. This staggered flowering may be an adaptive phenological offset, or reflection of microhabitat parameters unique for the individual plants. The great majority of plants at this site appeared to reach peak flowering within a week of one another.

2. Relation to climate and microclimate: Flowering started in the first week of August at least a week early in 1994 compared to the three following years. The 1994 season had exceptionally high July temperatures and low rainfall compared to the more average conditions of the following years.

It is reported that the species sets its floral primordium when it forms an overwintering rosette in fall (Arft 1995a). Flowering in other orchid species is determined with the formation of the perennating bud the season prior to anthesis. If this were the case, then a mild, long fall as occurred in 1996 may correlate with high flowering stem numbers in 1997, and the high number of flowering stems in 1994 may correspond with the exceptionally wet, mild 1993 season.

Conditions for seed set at the end of the growing season are also climatedependent. None of the mature capsules had dehisced to shed their seeds at the time of monitoring on September 4 in 1997. Conditions rarely get drier after this time for rupturing the capsule, so perhaps the capsules dehisce in response to temperature. It is likely that the minute seeds have a very short time to reach a safe site and become established before the growing season comes to a close. Unshattered capsules were found at the monitoring site in November long after the growing season ended.

\section{Reproductive ecology.}

1. Types of reproduction: Reproduction is sexual in the strict sense, though each year's plant comes from a separate lateral bud. Most orchids produce 
new tubers every year by lateral buds, thereby "spending their perennial life in a state of perpetual somatic youth" (Harper 1977, in Wells 1981). There was no evidence that lateral buds produced underground shoots, but in the course of collecting a voucher specimen, it was observed that the multiple, tuberously-thickened roots have high turgidity, without internal or external structure to prevent breakage, and they snap easily. While the great majority of plants are single-stemmed, a small number of multi-stemmed plants or small clumps were noted in settings that are trampled by livestock, presumably as a result of vegetative reproduction.

Outcrossing is promoted by protandrous flowers, the sequence of flowering that always begins with the bottom flower of the infloresence, and by acropetal movement of the bee pollinator on infloresences; though the flowers are fully self-compatible (Sipes and Tepedino 1995).

\section{Pollination.}

a. Mechanisms: Insect pollen vectors are required for sexual reproduction; primarily taking place through geitonogamy and xenogamy (Sipes and Tepedino 1995). The members of the Orchid Family are adapted to increase the likelihood of insect pollination by offering special attractions to a restricted set of potential pollinators, and to have the pollen stick together in masses so that many grains are transported and the many thousands of ovules in each flower are pollinated at once (Cronquist 1968, Stebbins 1974).

The species is in the late-season guild of flowering plant activity, which includes such late-blooming genera as Aster, Gentian, and Solidago. It is usually in low numbers and density and is pollinated by a generalist, perhaps depending on this guild and the earlier guilds to support its pollinator (after Buchmann and Nabhan 1996). The only occurrence where bumblebee visits were noted (EO\#001) had high densities of spotted knapweed (Centaurea maculata) flowering at the same time, a species also visited by bumblebees.

Most of the fruits that were observed in the Montana monitoring site appeared to be fertile. The only fruits observed during monitoring which may not have been fertile were the terminal infloresences which were late to mature. This contrasts with the high incidence of plants with infloresences made up of aborted fruits in, e.g., the Deer Creek population monitored by Arft (1995), ascribed to low pollinator activity. Additional cursory pollinator observations and fruit examinations may be warranted. 
b. Specific known pollinators: The only pollinator visits observed were late afternoon visits made by bumblebees (Bombus spp.), selectively visiting the species at EO\#001. This is also a site with extensive spotted knapweed, also visited by the bumblebees. Longtongued bumblebees are the most important pollinators elsewhere in its range (Sipes and Tepedino 1995). The bees are provided with nectar rewards, but the pollen are in "pollinia" (pollen masses) that are not available to them for food. The distinctive "coumarin" odor of the species (Sheviak 1984) suggests that there may be other rewards or benefits that flowers potentially offer their pollinators besides food such as sources of critical chemicals, e.g., for producing pheromes (after Buchmann and Nabhan 1996).

c. Other suspected pollinators: Only bumblebees have been noted to date visiting Spiranthes diluvialis flowers at one site in Montana. Elsewhere, an anthophorid bee, and hawkmoth were seen in single instances of also carrying the pollinaria of Spiranthes diluvialis (Sipes and Tepedino 1995).

d. Vulnerability of pollinators: The bumblebees are vulnerable to pesticides, and to land management practices that destroy available nest sites. There are both above ground and below ground nesting species of bumblebees (Sipes and Tepedino 1995, Arft 1995a), and the specific bumblebee pollination vector in Montana and its habitat vulnerability have yet to be identified.

\section{Seed dispersal.}

a. General mechanisms: The dust-like seeds of Orchid Family members are adapted to being carried by the wind (Cronquist 1968).

b. Specific agents: NA

c. Vulnerability of dispersal agents and mechanisms: NA

d. Patterns of propagule dispersal: The minute seeds may be carried great distances on the wind. If the capsules dehisce under cold temperatures, then the prevailing dispersal winds would be north winds.

\section{Seed biology.}

a. Amount and variation of seed production: Orchids have abundant, tiny "dust-like" seeds. Pollinators rarely visit a flower more than once, 
but carry pollen in masses called "pollinaria" so the many thousands of ovules per capsule are fertilized at once. Variation in seed production is conditioned by the effectiveness of the pollinators, as well as by the physiological state of the plant.

b. Seed viability and longevity: Seeds of orchids are very short-lived, with an undifferentiated embryo and little or no endosperm (Cronquist 1968). They have limited time span for germination after seeds dehisce and are generally considered to require endomycorrhizae to germinate in the field (Wells 1981).

c. Dormancy requirements: Seeds of orchids lack carbohydrate storage and thus lack the capacity for seed dormancy.

d. Germination requirements: Orchids seeds are very small and require a narrow range of moisture and temperature conditions to germinate. It is likely that they require direct contact with the mineral substrate.

e. Percent germination: Unknown.

5. Seedling ecology: Orchid seedlings are usually unable to continue growth without endomycorrhizal symbionts, the hyphae of which usually enters through the suspensor end to penetrate the germinating embryo (Dressler 1990). Species of Spiranthes initially become established as saprophytic, underground plants, dependent on the fungi for carbohydrates as well as nutrients and water. The ensuing underground stage is reported to last for 8 years in Spiranthes spiralis until a vegetative shoot is produced, and flowers are not produced until 13-14 years after germination (Wells 1967). By contrast, green leaves are produced in 2 years after germination by $S$. honkonganense (Sun 1995).

6. Survival and mortality: Stochastic and deterministic modeling of the monitored populations in Colorado and Utah projected population extinction for almost all of the populations under most agricultural practices except the "grazed only" population segment and to a lesser extent the "twice clipped" population segment under the deterministic model; and the unmanaged riparian populations under both the deterministic and stochastic models (Arft 1995a).

Species' longevity and the primary causes of mortality are unknown. The mean life span expectancy of Spiranthes spiralis plants studied by Wells (1967) was calculated to be more than 50 years. 
7. Overall assessment of taxon's reproductive success: Seed set is high in one and possibly all Montana populations, but dispersal and recruitment may be limiting factors in the narrow autumn window for dispersal and establishment.

\section{Ecology of the taxon.}

A. General summary: Interspecific competition with other vascular plants and obligatory mycotrophic symbiosis appear to be the most significant biological interactions for the species.

B. Positive and neutral interactions: The root system has little surface area for adsorption and the species may have an obligate dependence on endomycorrhizae for adsorption of phosphorus and water as well as carbohydrates at certain stages and at some level. Blue green algae have also been noted within the roots of orchids.

The symbiotic fungi have been classified as members of the genus Rhizoctonia (Wells 1981), considered a "taxonomic nightmare" (Zettler 1997) because most do not produce stable forms with fruiting structures in pure cultures. More recent taxonomic work has recognized three new general formerly included in Rhizoctonia (Moore 1987), with the genus Epulorhiza most frequently associated with temperate terrestrial orchids (Currah and Zelmer 1992).

Part of the success of the Orchid Family may be ascribed to mycotrophic relation (Zettler 1997). The symbiotic relation between fungi and orchids has been examined more closely in recent decades and some have concluded that it is a form of parasitism on the part of the orchids, of little or no benefit to the fungi. Fungal hyphae proliferate within cortical cells forming extensive coils called "pelotons". The orchids digest the pelotons at a controlled rate balanced between digestion and re-infection, so that they are effectively "fungus managers" (Zettler 1997). This symbiosis may be particularly critical during the underground seedling stage, during the years in which mature plants remain belowground ("season-long dormancy" of Lesica and Steele 1994), and possibly at critical phenological stages in the season.

It has been noted that more common species of orchids may serve as "refugia" for the symbiotic fungi that sustain rarer orchid species of the same habitat (Zettler and Hofer 1997), though the fungi may also live separate from orchids. Presence of the northern bog orchid (Habenaria hyperborea) was documented at many sites of Spiranthes diluvialis in Montana and rangewide (Appendix B), the most likely fungal "refugia" if there is such a thing for its endomycorrhizae.

Pollination by bumblebees may not be an obligate interaction, but results in greater seed production as represented by fruiting capsule mass than does self-pollination (Sipes and Terpedino 1995). 


\section{Negative interactions.}

1. Herbivores, predators, pests, parasites and diseases: Leaves of Spiranthes diluvialis at most sites showed signs of browse. Even those plants represented by immature rosette leaves under a continuous canopy cover of grass, located in the monitoring study, had browse on one or more leaves, though sometimes only the tip of the leaf. Some of the browsing may be caused by whitetail deer because their numbers are high in the general area and there is evidence (scat, bedding, tracks, direct observation) that they use the same habitat. Alternatively, it may be caused by smaller mammals. In any case, there are not the accompanying swathes of vegetation removal characteristic of grazing livestock as was seen when livestock were in pastures at the same time as Spiranthes diluvialis flowering.

Livestock grazing takes place at almost all of the occurrences though it tends to be earlier in the growing season when the uplands are still green rather than during flowering when only the wetlands are green. Clear signs of trampled plants were found at the monitoring site where livestock grazing overlapped with the flowering period in part of one season. This species has a fragile stem and leaves which are readily broken or damaged. The substrate is also subject to trampling when it is wet.

Browsing of the flowering stem has not been observed in Montana. By contrast, vole herbivory of infloresences was identified as a significant threat to the long-term survival of Spiranthes diluvialis at one Colorado site (Arft 1995a).

Weevils were observed browsing some infloresences in one Gallatin and one Jefferson County occurrence.

\section{Competition.}

a. Intraspecific: Individual plants are unlikely to compete with one another and may in fact aid in cross-pollination. Plant densities in Montana are low compared to those documented in a Colorado monitoring site (Arft 1995) . A relatively high density in Montana is five plants per $1 \times 1 \mathrm{~m}$. Two of the ten occurrences had no more than a total of one or two plants flowering in the entire survey area that year. 
b. Interspecific: Species in similar zones which appeared to be negatively correlated with local Spiranthes diluvialis distribution are likely competitors, including: Calamagrostis inexpansa,Carex praegracilis Elymus trachycaulus and others. Some monoculture species like cattail (Typha latifolia) probably represented hydrological alteration of habitat from mowing and irrigation rather than direct competition. Exotic species that appeared to be significant competitors include at least Festuca elatior, but exotic species like Agrostis stolonifera are strongly associated with it.

3. Toxic and allelopathic interactions: None are known. It is often in locales where Trifolium frageriferum is present, and sometimes Trifolium repens, but it is absent from the immediate vicinity of these exotic nitrogen-fixing legumes. The exotic legumes may affect the rhizosphere nutrient condition, competition, and/or mycorrhizae as required by Spiranthes diluvialis, though they are not known to be allelopathic.

\section{Hybridization.}

1. Naturally occurring: There was no evidence of hybridization. It is parapatric with $S$. romanzoffiana in some of the same counties, though it is in far different settings and habitats such that they are unlikely to be even in the same townships for cross-pollination to take place.

2. Artificially induced: No record.

3. Potential in cultivation: Research into seed germination, propagation and transplanting was being conducted by the Red Butte Gardens of Salt Lake City, and the Denver Botanic Gardens.

E. Other factors of population ecology: None known.

9. Current land ownership and management responsibility.

A. General nature of ownership: The ten occurrences include 1-6 different ownerships per occurrence. The species is found primarily on privately-owned land, but part or all of three occurrences are on state-administered land.

B. Specific landowners (Montana): Landowner information is summarized on the next page. 
No. of owners State agency

$\begin{array}{lll}001 & 1 & - \\ 002 & 1 & - \\ 004 & 6 & \text { MT Dept. Natural Resources } \\ 005 & 1 & - \\ 006 & 1 & - \\ 007 & 2 & - \\ 008 & 1 & \text { MT Dept. Transportation } \\ 009 & 1 & - \\ 010 & 2 & \end{array}$

C. Management responsibility: Private, with the exception of state-administered tracts referenced above.

D. Easements, conservation restrictions, etc.: None.

10. Management practices and experience.

\section{A. Habitat management.}

1. Review of past management and land use experiences.

a. This taxon: Indirect information is available from the management response research of Arft (1995a) with regard to grazing, haying, and idleness for the species in Colorado and Utah (Note: there were no controls). Inferrence can also be made through Montana observations.

Livestock grazing is the historic land use throughout this species' habitat in Montan. The species' persistence within suitable habitat coincides with the persistence of ranching. It was not found in settings with intense grazing where there had been a conversion in vegetation type to exotic grasses. It was not found in pastures grazed season-long by horses even though the range was in good condition. 
The only place where it was found under late-summer grazing was in a lightly-stocked bull pasture. The two largest species' populations at the time of listing had a history of winter-grazing, more notable for their intact vegetation condition than for signs of grazing (U.S. Fish and Wildlife Service 1992).

There were no mowing activities observed in its habitat because the setting remains wet and is oriented in winding narrow bands. Mowing takes place in some of the adjoining uplands, and those meandered wetlands surrounded by hayland were particularly choked with exotic grasses or cattails compared to nearby sites supporting Spiranthes diluvialis,. Mowing may have historically taken place within the few occurrences in swale wetlands when machinery was smaller and lighter, but there were no signs of it.

Irrigation and water diversions are common in the area, and some sites adjoin active or plugged man-made ditches. They are part of a system for providing water to agricultural lands that are mainly higher up in the landscape. Some of the natural meandered wetlands provide overflow for irrigation water. The net affect on Spiranthes diluvialis habitat appears to be the raising of the water levels because filtration takes place from the ditch or natural channel out to the surroundings. The occurrence that seems most affected by irrigation water discharge is also the most extensive occurrence (\#004). It is interesting to note that one terrace swale area formerly innundated by ditch seepage (owner pers. commun.) now has the ditch plugged and a large numbers of Spiranthes diluvialis (\#005) in the swale below. Some road ditches are hydrologically tied to the meandered wetlands, though there was not evidence that they contribute to the dewatering or innundation of the natural wetland habitat.

Roads and railroads lace the valleybottoms in which the species occurs, and several occurrences are partially or wholly within 0.1 mile of county road. This proximity is not a management conflict, except insofar as the roads become corridors for the spread of noxious weeds. One occurrence is restricted to a roadside right-of-way but the present level of use by dirt-bikers and horse-back riders traveling along the road is light or absent and damage was not found among plants.

b. Related taxa: There have been many management response studies and literature reviews pertaining to orchid species and their response to various land management practices. The most closely-related species and species' habitat for comparison with Spiranthes diluvialis is $S$. magnicamporum. A literature review of its management 
responses may help in designing management response studies for Spiranthes diluvialis.

c. Other ecologically similar taxa: Literature searches on other orchid species of the Great Plains and Great Basin may also provide a resource for designing and conducting management response research, as mentioned above. In addition, Habenaria hyperborea frequently occurs with Spiranthes diluvialis in Montana, occupies similar microhabitats, and may provide a possible study surrogate.

2. Performance under changed conditions: There is limited basis for commenting on this among Montana populations. One swale area formerly innundated by ditch seepage (owner pers. commun.) now has the ditch plugged and a large numbers of Spiranthes diluvialis (\#005) in the swale below.

3. Current management policies and actions: There are no current agency management policies or actions involving this species in Montana.

4. Future land use: All of the current EOs occupy settings which can readily be degraded, if not also plowed. Mapping of wetland habitat for tax credit purposes is underway at least in Gallatin County, but it is not known whether the narrow channels as occupied by the species are consistently demarcated.

\section{B. Cultivation.}

1. Controlled propagation techniques: None. Efforts to propagate Spiranthes diluvialis are underway at Denver Botanic Gardens and the Red Butte Gardens of Salt Lake City.

2. Ease of transplanting: Salvage operations involving several hundred plants at a Utah site were carried out. The were transplanted into raised beds with drip irrigation and subsurface drainage at the Red Butte Gardens (Meyer 1995).

3. Pertinent horticultural knowledge: Propagation of orchids is of considerable horticultural interest (Allen 1996) and has usually usually been done without the symbiosis. But some species like Spiranthes diluvialis have never been successfully propagated apart from their endomycorrhizae.

4. Status and location of presently cultivated material:

a. Specimen plants: None. 


\section{b. Self-sustaining breeding populations: None.}

c. Stored seed: None. The value of saving orchid seeds in a seedbank without the fungal symbiont has been debated by mycologists (Zettler 1997).

\section{Evidence of threats to survival.}

\section{A. Present or threatened destruction, modification, or curtailment of habitat or} range: Alteration of river flow regimes does not directly threaten the species in the same way or magnitude as the riverside occurrences in much of the rest of its range where channelization and impoundment are major threats (U.S. Fish and Wildlife Service 1992). Yet the Montana occurrences may still fit within the pattern of imperilment shared by many Western species of declining under altered surface waters (Flather et al. 1994). Its highly restricted microhabitats are linked to shallow, stable groundwater in temporarily inundated emergent wetlands. These may be affected at some level by small water diversions, ditches, and irrigation discharges which are widespread.

The soils are marginally suited to crop production, windbreaks, and homestead development. Nevertheless, its habitat is being cultivated, often with use of irrigation, altered by neighboring water diversions or inflows, and affected by valleybottom developments including roads systems and buildings. There is not the threat of urbanization as identified for Colorado occurrences (U.S. Fish and Wildlife Service 1992), except for one occurrence that lies directly outside of city limits where development could occur. The spread of noxious weeds that often accompanies developments is a more pervasive, if not more severe threat for Montana occurrences.

Noxious weeds including leafy spurge (Euphorbia esula), spotted knapweed (Centaurea maculosa) and Russian knapweed (Centaurea repens) are the most pervasive immediate threats. They are threats as competitors, and in the indiscriminate spraying of herbicides to treat them. Fortunately, noxious weed invasion is absent or at early stages in the Spiranthes diluvialis habitat of the ten occurrences, though a couple have severe weed infestation problems nearby. The invasion of knapweeds is concentrated mainly along roads and irrigation canals. The invasion of leafy spurge is most serious along water courses, but it is also spreading in a patchy, more difficult to predict pattern that may reflect the influence of wildlife vectors like whitetail deer and mourning doves that are common in the bottomlands. The indiscriminate treatments of noxious weeds and rangeland pests with herbicides and pesticides also pose a potential threat.

B. Overutilization for commercial, sporting, scientific, or educational purposes: Collecting of this species is regulated under authority of the Endangered Species Act 
(16 USF 1539 [a] and 1533 [d]). It is to be discouraged except to initially document new county records at large populations, or for approved non-destructive collection in conjunction with priority research.

The largest one-time collecting of this species in Montana took place for collecting five plants for chromosome counts (inflorescence and stalk). This initial Jefferson County collection is documented by specimens at NYS and MONTU. The largest Madison County occurrence was documented by a specimen at MONTU. The only Beaverhead County occurrence is documented by a specimen at MONT. There is only one Gallatin Co. occurrence which might be considered adequately large for collecting a voucher specimen in the future, in keeping with conservation-minded collecting guidelines (Montana Native Plant Society 1993), but it has not been collected. Collecting of the Jefferson, Madison, and Beaverhead voucher specimens was conducted under subpermit 95-39.

Collection labels should not include location information beyond the township. Location information for this species is treated as sensitive in Montana to protect the species, its readily-accessible habitat, and the private property owners. Its element occurrence printouts do not include location information beyond the township, and fine-scale GIS map products simply note its presence on the area of consideration without showing location.

This species is the showiest and among the most conspicuous in the local late-season flora. Any activities which draw local attention to the Montana sites may elevate collection pressure however innocent the motives.

C. Disease, predation, or grazing: Almost all sites are currently used for cattle grazing as part of a pasture rotation, and it appears that the persistence of the species in Montana hinged on the presence of private rangeland. However, livestock were not found in the pastures during the time of flowering, and grazing is considered to have a potential impact under certain conditions. Late-season grazing and seasonlong grazing correlate with low flower production (Arft 1995a), and any intense grazing when soils are saturated has the potential to trample the species if not convert the vegetation cover and intensify competition. The sites of two occurrences are idle; one is a roadside right-of-way disturbance setting that is somewhat analogous to the natural habitat, and the other is a small pocket of natural habitat surrounded by roads and tamegrass plantings.

Information on the nest requirements of the bumblebee pollinator is seriously needed, along with consideration of the potential affects of grazing on the bumblebee.

D. Inadequacy of existing regulatory mechanisms: Only one of the ten populations has statutory protection because it occurs on state lands administered in part with federal highway funds. 
However, removal of plants in knowing violation of any state laws, including criminal tresspass laws, is addressed under the Endangered Species Act. Thus, continued posting of privately-owned occurrences, presenting all pertinent information to the landowners, and maintaining location data as sensitive affords a small measure of protection.

\section{E. Other natural or man-made factors: None known.}

\section{ASSESSMENT AND RECOMMENDATIONS}

12. General assessment of vigor, trends, and status: All Montana populations have potential threats and are vulnerable, but imminent threats were not identified. There are no Montana occurrences in natural settings which are protected. Local land use patterns suggest that the species habitat has declined, but there is no site-specific trend data.

\section{Recommendations for listing or status change}

A. Recommendation to U.S. Fish and Wildlife Service: Status recommendations for plants hinge on rangewide conditions, so that any state status report is necessary but insufficient grounds for recommending status change unless it represents all of the range or it provides the sole basis for status change. This status report represents 10 occurrences (over $10 \%$ of the rangewide total) and numbers of over 1,400 flowering plants (less than $10 \%$ of the rangewide total) in one of eight states. When the species was originally listed, it was known from 10 extant sites and 7 historic sites, with the total number of plants among extant occurrences conservatively estimated at 6,000 plants (U.S. Fish and Wildlife Service 1992).

The Montana information does not provide grounds for making a rangewide status decision for de-listing. It is a state update to be incorporated in rangewide status update.

B. Recommendations to other U.S. federal agencies: It will be brought to the attention of Federal Highway Administration contacts because of its proximity to the I-90 interstate corridor. In addition, federal agencies like NRCS that work with private landowners need sound information on the species.

\section{Other status recommendations.}

\section{Counties and local areas: None.}

2. States: It is recommended that this information be pooled with the most current rangewide status information including at least a summary of distribution, abundance, threats, and protection; and that global rank be reevaluated. 
The three state agencies in Montana that administer lands with this species have been informed of its occurrence.

\section{Other nations: None.}

4. International: None.

14. Recommended critical habitat: Critical habitat was not designated for this species and it was not addressed in the survey.

15. Conservation/recovery recommendations.

A. General conservation recommendations.

1. Recommendations regarding present or anticipated activities.

a. Draft Section 7 guidelines have been prepared for the species in Montana (Appendix E). There is need for a map of potential habitat to accompany it.

b. The state agencies administering land with this species do not have botanists on staff working with rare species, nor do the federal and state agencies working with private landowners. A species workshop is being planned for 1998 to provide a framework and coordination for addressing the species.

c. Monitoring was initiated at one site with landowner permission in 1996. A review of monitoring objectives and design is needed, with special regard to results from the previous monitoring conducted by Arft (1995a), along with analysis of data collected to date.

2. Areas recommended for protection: The two largest populations (EO \#005 and \#011) and the most extensive population (EO\#004) are the highest priorities for landowner contact and protection consideration.

3. Habitat management recommendations: Interim management guidelines have been prepared for the first site at which the species was discovered, at the request of the landowner.

4. Publicity sensitivity: The presence of this species in Montana was first publicized in the Montana Outdoors Magazine (Aderhold 1995) and a short article in the Montana Native Plant Society Newsletter (Heidel 1996b) as well as in a technical publication (Heidel 1996a). It will be profiled in a Montana Audubon fact sheet in a series on Montana's threatened and endangered species. It was the topic of a technical presentation at the Montana Rare Plant 
Conservation Conference and a general audience presentation at a Montana Native Plant Society program.

Its conservation planning and occurrences are treated as sensitive data because they are on highly accessible land, they have no protection, and private landowners are to be spared unwelcome publicity. It may also be a sensitive topic because of the controversy associated with threatened and endangered animals in Montana.

5. Other recommendations: Coordination is needed between botanists working on Spiranthes diluvialis and considering its status, recovery, and Section 7 guidelines. Genetic comparison of the new range extensions with the Colorado and Utah material would be useful in considering conservation priorities.

Additional information is needed on the habitat requirements and may also be needed on the status of its pollinator(s) and on the levels of fruit set among Montana occurrences.

Systematic survey work needs to be completed on tracts adjoining four EOs (\#007, \#008, \#009 and \#011).

Noxious weed control is needed at almost half of the occurrences, including two of the three largest (\#001, \#004, \#005, \#009). These are a high priority for consultation involving the landowners and the Natural Resources Conservation Service, and for cost-sharing with landowners.

Preliminary hydrological consultation on the groundwater source and stability is also recommended. The origin of the wetlands may also shed light on the habitat specificity and hydrology.

B. Monitoring activities and research needs: Continued monitoring of EO\#001 is recommended pending literature synthesis and statistical consultation.

\section{Interested parties:}

Office of Endangered Species

U.S. Fish and Wildlife Service

P.O. Box 25486

Denver Federal Center

Denver, CO 80225 
U.S. Fish and Wildlife Service

ATTN: Lori Nordstrom, Dale Harmes

Federal Building, 301 S. Park

P.O. Box 10023

Helena, MT 59626

Office of Endangered Species

ATTN: Dr. John Fay

U.S. Fish and Wildlife Service

Washington, D.C. 20240

The Nature Conservancy

ATTN: Dr. Larry Morse

1815 North Lynn Street

Arlington, VA 22209

The Nature Conservancy

Montana Field Office

ATTN: Jamie Williams

32 South Ewing

Helena, MT 59601

Montana State Library

Montana Natural Heritage Program

ATTN: Sue Crispin, Bonnie Heidel

State Library Building

1515 E. 6th Ave.

Helena, MT 59620-1800

Montana Department of Transportation

ATTN: Joel Marshik, Larry Urban

2701 Prospect Ave.

Helena, MT 59620-1001

Montana Department of Fish, Wildlife and Parks

Headquarters Region 3

ATTN: Ray Heagney

1400 S. $19^{\text {th }}$

Bozeman, MT 59715 
Montana Department of Natural Resources

Dillon Unit Office

ATTN: Stan Vlahovich

730 N. Montana

Dillon, MT 59725

Montana Native Plant Society

P. O. Box 8783

Missoula, MT 59807-8783

Montana Audubon Society

324 Fuller Avenue

Helena, MT 59601

\section{INFORMATION SOURCES}

\section{Sources of Information.}

\section{A. Publications.}

1. References cited in report: See Literature Cited (pp. 52-55).

2. Other publications/sources: The species is featured in state sensitive species guides of Colorado, Utah, and Wyoming in addition to the Montana guide posted on the Internet.

B. Museum collections: Montana specimens are deposited at the New York Biological Survey (NYS), University of Montana (MONTU) and Montana State University (MONT) as follows: B. Heidel \#1245 NYS, MONTU representing Jefferson Co; B. Heidel \#1523 MONTU representing Madison Co., and B. Heidel \#1600 MONT representing Beaverhead Co. All were collected under the U.S. Fish and Wildlife Service collecting permit authority PRT-704930. No voucher material has been collected from Gallatin Co. to date.

C. Fieldwork.

1. Surveys conducted: B. L. Heidel (MTNHP): August 6-7, 12-13, 15-16, 24, 1996; and August 11-14, 18-21, 23, 25, 28-29, Sept. 4 and 20, 1997 (includes monitoring) 
D. Knowledgeable individuals:

(technical contacts re. Montana occurrences)

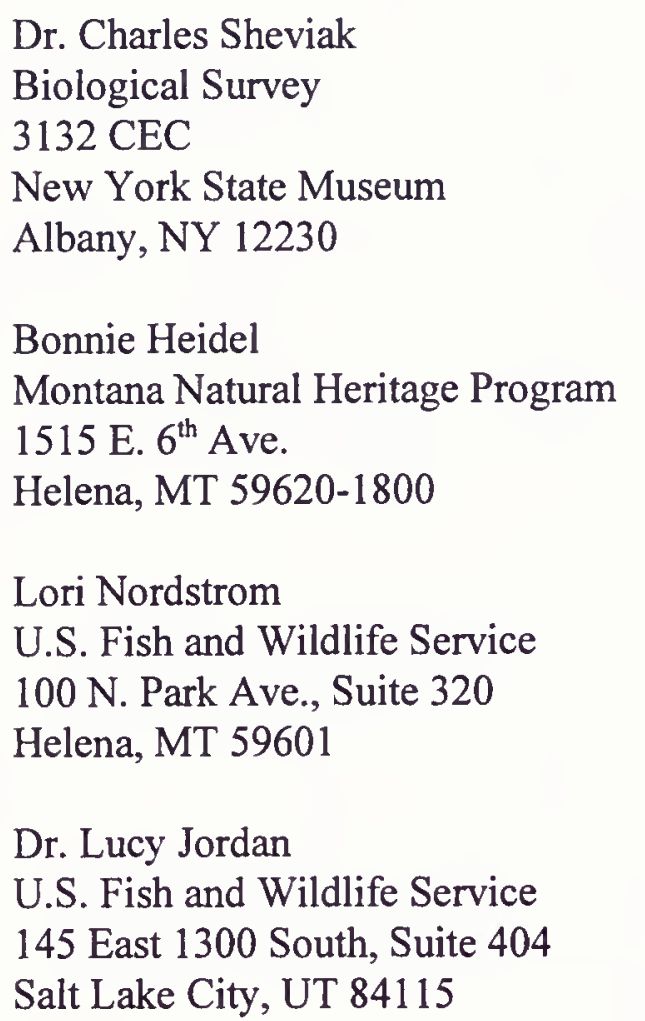

18. Summary of materials on file: Field survey forms, field maps, and photos are filed at the Montana Natural Heritage Program. Most of the references cited in this report are compiled and stored in the element file, botany reprint files and book shelves, and cross-referenced in the Source Abstract data files.

\title{
AUTHORSHIP
}

19. Initial authorship:

\author{
Bonnie L. Heidel \\ Montana Natural Heritage Program \\ 1515 East Sixth Avenue \\ Helena, MT 59620-1800
}

20. Maintenance of status report:

The Montana Natural Heritage Program will maintain occurrence information and may update the status report as needed. 


\section{NEW INFORMATION}

21. Record of revisions: This final status report replaces the interim status report, updating chapters 1-7 and completing chapters 7-21.

\section{Literature Cited}

Aderhold, M. 1996. Montana's threatened species. Montana Outdoors 27(3):6-9.

Allen, C., ed. 1996. Proceedings of the North American Native Terrestrial Orchid Propagation and Production Conference. Washington, D. C.

Arft, A. M. 1995a. The genetics, demography, and conservation management of the rare orchid Spiranthes diluvialis. $\mathrm{PhD}$ thesis. University of Colorado, Boulder. $170 \mathrm{pp}$.

Arft, A. M. 1995b. The demography and conservation management of the rare orchid Spiranthes diluvialis (Orchidaceae). Unpublished report to the Colorado Natural Areas Program. University of Colorado, Boulder. 17 pp. + app.

Boast, R. R. and R. G. Shelito. 1989. Soil Survey of Madison County Area, Montana. USDA Soil Conservation Service, Bozeman, MT. 384 pp. + maps.

Buchmann, S. and G. Nabhan. 1996. The Forgotten Pollinators. Island Press. Washington, D.C. $292 \mathrm{pp}$.

Clements, M. A. 1988. Orchid mycorrhizal associations. Lindleyana 3:73-86.

Cronquist, A. 1968, 1st ed. The evolution ad classification of flowering plants. Houghton Mifflin Co., Boston. 396 pp.

Dorn, R. D. 1984. Vascular Plants of Montana. Mountain West Publishing, Cheyenne, WY. 276 pp.

Dressler, R. L. 1990. The Orchids, Natural History and Classification. Harvard University Press, Cambridge, MA. 332 pp.

Fenneman, N. M. 1931. Physiography of Western United States. McGraw-Hill Book Co., New York. $534 \mathrm{pp}$.

Fertig, W. 1994. Spiranthes diluvialis (Ute Lady's Tresses) - Wyoming's First Listed Threatened Plant Species. Castilleja 13(2): 3. Wyoming Native Plant Society Newsletter.

Flather, C. H., L. A. Joyce, and C. A. Bloomgarden. 1994. Species endangerment patterns in the United States. Washington (DC): USDA Forest Service, Rocky Mountain Forest and Range Experimental Station. Gen. Tech. Rep. RM-241. 
Great Plains Flora Association, 1986. Flora of the Great Plains. University of Kansas Press, Lawrence. $1392 \mathrm{pp}$.

Hansen, P. L., R. D. Pfister, K. Boggs, G. J. Cook, J. Joy and D. K. Hinckley. 1995. Classification and management of Montana's riparian and wetland sites. Montana Forest and Conservation Experiment Station Misc. Pub. No. 54. Missoula. 646 pp.

Hazlett, D. L. 1996. The discovery of Spiranthes diluvialis along the Niobrara River in Wyoming and Nebraska. Unpublished report to the Bureau of Land Management, Wyoming. $16 \mathrm{pp}$.

Hazlett, D. L. 1997. A 1997 Search for Spiranthes diluvialis in Southeastern Wyoming and Western Nebraska. Unpublished report for the Bureau of Land Management, Wyoming. $12 \mathrm{pp}$.

Heidel, B. L. 1995. Whitehall botanical site evaluation, Jefferson County, Montana. Unpublished report. $26 \mathrm{pp} .+$ app.

Heidel, B. L. 1996a. New additions to the Montana flora. Madroño 43(3):436-440.

Heidel, B. L. 1996b. Spiranthes diluvialis - A Threatened orchid in Montana. Kelseya 9(3) Newsletter of Montana Native Plant Society.

Hildebrand, T. 1998. 1997 Inventory for Spiranthes diluvialis Sheviak in western Nebraska. Unpublished report to the U.S. Fish and Wildlife Service. Nebraska Game \& Parks Commission, Lincoln. 25 pp. + app.

Hitchcock, C. L., A. Cronquist, M. Ownbey and J. W. Thompson. 1994, 6th ed. Vascular Plants of the Pacific Northwest, Vol. 1.

Jennings, W. F. 1989. Species studies: Eustoma grandiflorum, Spiranthes diluvialis, Malaxis brachypoda, Hypoxis hirsuta, Physaria bellii, Aletes humilis. Unpubl. Rep. to Colorado Office of The Nature Conservancy. $48 \mathrm{pp}$.

Kuchler, A. W. 1964. The potential natural vegetation of the conterminous United States. Amer. Geogr. Soc. Special Rep. No. 36. American Geographical Society, New York.

Kuenzi, W. D. and R.W. Fields. 1971. Tertiary stratigraphy, structure, and geologic history, Jefferson Basin, Montana. Geol. Soc. Amer. Bull. 82:3373-3394.

Lesica, P. 1990. Vegetation and sensitive plant species of wetlands associated with geothermal areas in the Greater Yellowstone Ecosystem in Montana. Unpublished report to The Nature Conservancy. $8 \mathrm{pp}$. plus app. 
Lesica, P. and B. M. Steele. 1994. Prolonged dormancy in vascular plants and implications for monitoring studies. Natural Areas Journal 14(3): 209-212.

Meyer, T. 1995. Red Butte Garden and Arboretum - Spiranthes diluvialis update, February 1995. Unpublished abstract provided to U.S. Fish and Wildlife Service.

Moseley, R. K. 1997. Ute ladies' tresses (Spiranthes diluvialis): Preliminary status in Idaho. Unpublished report to U.S. Fish and Wildlife Service. Idaho Department of Fish and Game. Boise. 11 pp. plus appendices.

Moseley, R. K. 1997. Memo of 7 October and preliminary information packet summarizing 1997 Spiranthes diluvialis survey results. Idaho Conservation Data Center, Boise.

National Oceanic and Atmospheric Administration 1982. Monthly normals of temperature, precipitation, and heating and cooling degree days, 1951-1980 - Montana. Climatography of the United States No. 81. U.S. Department of Commerce. (by state).

National Oceanic and Atmospheric Administration. 1992. Monthly station normals of temperature, precipitation and heating and cooling degree days, 1961-1990 - Montana. Climatography of the United States No. 81. U.S. Department of Commerce.

Nell, D. F. and J. E. Taylor. 1996. Lewis and Clark in the Three Rivers Valleys, Montana 18051806. Headwaters Chapter of the Lewis \& Clark Trail Heritage Foundation, Inc. and The Patrice Press, Tucson, AZ. 284 pp. + map.

Olsen, J. A., M. H. Haub, and L. C. Bingham. 1977. Soil survey of Broadwater County Area, Montana. USDA Soil Conservation Service, Bozeman, MT.

Reichmuth, D. R. 1986. Fluvial systems in the wetland environment. Pp. 23-59. In: Great Basin/Desert and Montana Regional Wetland Functions. Proceedigs of a National Wetlands Technical Council Workshop held in Logan, UT.

Riedel, S. Petersburg and T. Naumann. 1995. Spiranthes diluvialis monitoring and habitat restoration, 1995 update, Dinosaur National Monument, National Park Service. 6 pp. plus attachments.

Sheviak, C. J. 1984. Spiranthes diluvialis (Orchidaceae), a new species from the western United States. Brittonia $36(1): 8-14$.

Sipes, S. D. and V. J. Tepedino. 1995. Reproductive biology of the rare orchid, Spiranthes diluvialis: breeding system, pollination, and implications for conservation. Conservation Biology 9(4):929-938.

Smith, J. P. 1977. Vascular Plant Families. Mad River Press, Inc. Eureka, CA. 
Stebbins, G. L. 1974. Flowering Plants. Belknap Press of Harvard University Press. Cambridge, MA. 399 pp.

Sun, M. 1995. Effects of population size, mating system, and evolutionary origin on genetic diversity in Spiranthes sinensis and S. hongkongensis. Conservation Biology 10(3):785-795.

Tamm, C. O. 1972. Survival and flowering of some perennial herbs. II. The behavior of some orchids on permanent plots. Oikos 23(1):23-28.

U. S. Bureau of Land Management. 1996. Special status species management in Montana. BLM Manual Supplement 6840, of 8 April 1996. Billings, MT.

U.S. Fish and Wildlife Service. 1992. Endangered and threatened wildlife and plants; final rule to list the plant Spiranthes diluvialis (Ute ladies'-tresses) as a threatened species. Federal Register 57: (12):2048-2054.

U.S. Fish and Wildlife Service. 1995a. Recommendations and guidelines for Ute ladies'-tresses orchid (Spiranthes diluvialis) recovery and fulfilling Section 7 consultation responsibilities. Utah Field Office, Salt Lake City. 19 pp. + app.

U.S. Fish and Wildlife Service. 1995b. Ute ladies'-tresses (Spiranthes diluvialis) - agency review draft recovery plan. Utah Field Office, Salt Lake City. 46 pp.

Visher, S. S. 1954. Climatic Atlas of the United States. Harvard University Press, Cambridge. $403 \mathrm{pp}$.

Wells, T. C. E. 1967. Changes in a population of Spiranthes spiralis (L.) Chevall. at Knocking Hoe National Nature Reserve, Bedfordshire, 1962-65. J. Ecol. 55:83-99.

Wells, T. C. E. 1981. Population ecology of terrestrial orchids. The Biological Aspects of Rare Plant Conservation. H. Synge, ed. John Wiley \& Sons, Ltd. London.

Wyoming Rare Plant Technical Committee. 1995. Wyoming rare plant field guide. Cheyenne, WY.

Zelmer, C. D. and R. S. Currah. 1995. Evidence for a fungal liason between Corallorhiza trifida (Orchidaceae) and Pinus contorta (Pinaceae). Can. J. Bot. 73: 862-866.

Zettler, L. W. 1997. Orchid-fungal symbiosis and its value in conservation. Mcllvainea 13(1):4045.

Zettler, L. W. and C. J. Hofer. 1997. Propagation of the Little Club-spur Orchid (Platanthera clavellata) by symbiotic seed germination, and its ecological implications. Env. \& Expt. Botany. In press. 
Appendix A. Element Occurrence Printouts 
Scientific Name: SPIRANTHES DILUVIALIS

Common Name: UTE LADIES' TRESSES

Global rank: G2 Forest Service status:

State rank: S1 Federal Status: LT

Element occurrence code: PMORC2B100.001

Element occurrence type:

Survey site name: WHITEHALL

EO rank: $B C$

EO rank comments: SMALL POPULATION SIZE.

County: JEFFERSON

USGS quadrangle: WHITEHALL

Township: Range: Section: TRS comments:

$001 \mathrm{~N} \quad 004 \mathrm{~W} \quad 00$

Precision: S

Survey date: 1994-08-15 Elevation: 4350 -

First observation: 1994-08-03 Slope/aspect:

Last observation: 1996-08-24 Size (acres): 1

Location:

CONTACT THE MONTANA NATURAL HERITAGE PROGRAM.

Element occurrence data: 100+ PLANTS AS DETERMINED FROM FOUR YEARS OF OBSERVATION AND MONITORING.

71 FLOWERING STEMS IN 1994; 26 FLOWERING STEMS IN 1995 THAT WERE ALL SHORTER HEIGHT AND FEWER-FLOWERED COMPARED TO 1994; 49 FLOWERING STEMS IN 1996; 32 FLOWERING PLANTS IN 1997 PLUS 18 VEGETATIVE PLANTS.

General site description:

LOCALIZED WET MEADOW BORDER IN VALLEY BOTTOM SURROUNDED BY ALKALINE HABITAT. ASSOCIATED WITH CALAMAGROSTIS INEXPANSA, CAREX PRAEGRACILIS, AGROPYRON CANINUM, JUNCUS NODOSUS, GENTIANELLA AMARELLA, ASTER HESPERIUS, JUNCUS LONGISTYLIS. THE MOIST SETTING IS INUNDATED EARLY IN THE GROWING SEASON.

Land owner/manager:

PRIVATELY OWNED LAND (INDIVIDUAL OR CORPORATE)

Comments :

C. SHEVIAK CONFIRMED CHROMOSOME COUNT $2 \mathrm{n}=74$ IN UNPUBLISHED LAB ANALYSIS OF SPECIMENS FROM THE SITE. AT LEAST 3 PLANTS COUNTED IN 1995 TRAMPLED BY LIVESTOCK.

Information source: HEIDEL, BONNIE. [BOTANIST] MONTANA NATURAL HERITAGE PROGRAM, 1515 EAST SIXTH AVENUE, P.O. BOX 201800, HELENA, MT 59620-1800. WORK: 406/444-3009.

Specimens: HEIDEL, B. (1245). 1994. MONT.

HEIDEL, B. (1316). 1994. MONTU. 
Scientific Name: SPIRANTHES DILUVIALIS

Common Name: UTE LADIES' TRESSES

Global rank: G2 Forest Service status:

State rank: S1 Federal Status: LT

Element occurrence code: PMORC2B100.002

Element occurrence type:

Survey site name: BEAVERHEAD RIVER

EO rank: DC

EO rank comments: HABITAT ALTERED BY LIVESTOCK

County: MADISON

USGS quadrangle: BEAVERHEAD ROCK

Township: Range: Section: TRS comments:

005S $\quad 007 \mathrm{~W} \quad 00$

Precision: S

Survey date: 1996-08-16 Elevation: 4785 -

First observation: 1996-08-16 Slope/aspect: LEVEL

Last observation: 1996-08-16 Size (acres): 5

Location:

CONTACT THE MONTANA NATURAL HERITAGE PROGRAM

Element occurrence data:

ONLY 1 PLANT FOUND IN LARGEST LOCAL AREA OF POTENTIAL HABITAT. IN PEAK FLOWERING 16 AUGUST 1996.

General site description:

BROAD MARL FLATS ALONG PART OF A SPRING-FED MEANDER THAT FEEDS INTO THE BEAVERHEAD RIVER. IN ELEOCHARIS PAUCIFLORA H.T. WITH ABUNDANT GLAUX MARITIMA, JUNCUS BALTICUS AND TRIGLOCHIA MARITIMA, AS WELL AS JUNCUS LONGISTYLIS, J. NODOSUS, MUHLENBERGIA RICHARDSONIS. SOILS ARE MARLY PEAT WITH A FIBRIC BROWN UPPER CALCAREOUS LAYER AND AN UNDERLYING BLACK, MORE HUMIC LAYER.

Land owner/manager:

PRIVATELY OWNED LAND (INDIVIDUAL OR CORPORATE)

Comments :

LONG HISTORY OF GRAZING AND HAYING ON THE BOTTOMS. MOST NATIVE ALKALI SACATON PLAINS ARE HEAVILY INVADED AND CODOMINATED BY QUACKGRASS.

Information source: HEIDEL, BONNIE. [BOTANIST] MONTANA NATURAL HERITAGE PROGRAM, 1515 EAST SIXTH AVENUE, P.O. BOX 201800, HELENA, MT 59620-1800. WORK: 406/444-3009.

Specimens : 
Scientific Name: SPIRANTHES DILUVIALIS

Common Name: UTE LADIES' TRESSES

Global rank: G2

State rank: S1

Forest Service status:

Federal Status: LT

Element occurrence code: PMORC2B100.004

Element occurrence type:

Survey site name: TWIN BRIDGES

EO rank: $A B$

EO rank comments: EXTENSIVE HABITAT, MOSTLY GOOD CONDITION, WITH

MANY SMALI SUBPOPULATIONS.

County: MADISON

USGS quadrangle: BEAVERHEAD ROCK NE BEAVERHEAD ROCK

Township: Range: Section: TRS comments:

004S $006 \mathrm{~W} \quad 00$

$004 \mathrm{~S} \quad 007 \mathrm{~W}$

Precision: $\mathrm{S}$

Survey date: 1996-08-12 Elevation: 4700 -

First observation: 1996-08-12 Slope/aspect: 0-1\% / VARIABLE

Last observation: 1997-08-29 Size (acres): 10

Location:

CONTACT THE MONTANA NATURAL HERITAGE PROGRAM.

Element occurrence data:

58 PLANTS COUNTED IN 1996; CA. 30 FOUND IN NEW SEGMENT IN 1997 FOR

ACTUAL COUNT OF CA. 100+ ALONG MANY MILES OF MEANDERED WETLAND.

General site description:

EXTENSIVE MARL FLAT MARGINS ALONG SLOUGH AND OTHER ADJOINING MEANDERED WETLANDS IN THE BUFFALOBERRY BOTTOMS OF THE BEAVERHEAD RIVER VALLEY. HABITAT TYPES INCLUDE CAREX SIMULATA AND TYPES DOMINATED OR CODOMINATED BY ELEOCHARIS PAUCIFLORA. OTHER ASSOCIATED SPECIES INCLUDE PRIMULA INCANA, HABENARIA HYPERBOREA, TRIGLOCHIN PALUSTRIS, MUHLENBERGIA FILIFORMIS, M. RICHARDSONIS, JUNCUS NODOSUS, AND SPHENOPHOLIS OBTUSATA.

Land owner/manager:

PRIVATELY OWNED LAND (INDIVIDUAL OR CORPORATE)

STATE LAND - UNDESIGNATED

Comments :

EXTENSIVE HABITAT WITH MANY SMALL POPULATIONS. THE OCCUPIED HABITAT IS IN GOOD CONDITION BUT THE EXTENT OF HABITAT MAY BE AFFECTED BY IRRIGATION AND LIVESTOCK GRAZING. EUPHORBIA ESULA IS BEGINNING TO INVADE NEARBY.

Information source: HEIDEL, BONNIE. [BOTANIST] MONTANA NATURAL HERITAGE PROGRAM, 1515 EAST SIXTH AVENUE, P.O. BOX 201800, HELENA, MT 59620-1800. WORK: 406/444-3009.

Specimens: HEIDEL, B. (1523). 1996. MONTU. 
Scientific Name: SPIRANTHES DILUVIALIS

Common Name: UTE LADIES' TRESSES

Global rank: G2 Forest Service status:

State rank: SI Federal Status: LT

Element occurrence code: PMORC2B100.005

Element occurrence type:

Survey site name: JEFFERSON RIVER VALLEY

EO rank: $A B$

EO rank comments: SMALI POPULATION AREA, RELATIVELY HIGH DENSITY; GRAZING, SOME NON-NATIVE SPECIES.

County: JEFFERSON

USGS quadrangle: VENDOME

Township: Range: Section: TRS comments: 001N $004 \mathrm{~W} \quad 00$

$\begin{array}{rll}\text { Precision: } & \text { S } & \\ \text { Survey date: } & 1996-08-15 & \text { Elevation: } 4395-4400 \\ \text { First observation: } 1996-08-15 & \text { Slope/aspect: 0\% / LEVEL } \\ \text { Last observation: } 1997-08-11 & \text { Size (acres): } 20\end{array}$

Location:

CONTACT THE MONTANA NATURAL HERITAGE PROGRAM.

Element occurrence data:

OVER 500 PLANTS IN FOUR SUBPOPULATIONS AND IN RELATIVELY HIGH DENSITY. MOST PLANTS NEAR PEAK FLOWERING ON 15 AUGUST 1996, BUT A FEW ENTIRELY IN BUD AND A FEW NEAR SENESENCE. THE THREE WESTERN SUBPOPULATIONS HAD OVER 100 PLANTS IN 1997 (ACTUAL COUNT), WITH 175 IN THE BIGGEST MEADOW AREA .

General site description:

MARL PEATLAND COMPLEX ASSOCIATED WITH SEEP-FED MEADOWS AT THE EDGE OF THE JEFFERSON RIVER VALLEY. THE PLANT COMMUNITY WEST OF THE OXBOW IS LOCALLY DOMINATED BY DIMINUTIVE SPECIES INCLUDING ELEOCHARIS PAUCIFLORA, MUHLENBERGIA RICHARDSONIS, CAREX SIMULATA AND GLAUX MARITIMA. THE REST OF THE HABITAT HAS CO-DOMINANCE THAT INCLUDES AGROSTIS STOLONIFERA AND JUNCUS BALTICUS. OTHER ASSOCIATED SPECIES INCLUDE TRIFOLIUM FRAGERIFERUM AND HABENARIA HYPERBOREA. SOILS ARE MARLY PEAT WHICH ARE FIBRIC AND BROWN IN UPPER INCH BUT BLACK AND MORE HUMIC BELOW.

Land owner/manager:

PRIVATELY OWNED LAND (INDIVIDUAL OR CORPORATE)

Comments :

LANDOWNER NOTED THAT THE DITCH TO THE WEST OF THIS OCCURRENCE FORMERLY INUNDATED MUCH OF THIS HABITAT WHEN THE DITCH WAS IN USE.

Information source: HEIDEL, BONNIE. [BOTANIST] MONTANA NATURAL HERITAGE PROGRAM, 1515 EAST SIXTH AVENUE, P.O. BOX 201800, HELENA, MT 59620-1800. WORK: 406/444-3009.

Specimens: 
Scientific Name: SPIRANTHES DILUVIALIS

Common Name: UTE LADIES' TRESSES

Global rank: $\mathrm{G} 2$

State rank: S1

Forest Service status:

Federal Status: LT

Element occurrence code: PMORC2B100.006

Element occurrence type:

Survey site name: ALDER

EO rank: $C D$

EO rank comments: GOOD POPULATION SIZE IN DISTURBED SETTING SIMULATING NATURAL CONDITIONS.

County: MADISON

USGS quadrangle: ALDER

Township: Range: Section: TRS comments:

006S $\quad 004 \mathrm{~W}$

Precision: S

Survey date: 1997-08-14 Elevation: 5080 -

First observation: 1997-08-14 Slope/aspect: 0-108 / -

Last observation: 1997-08-14 Size (acres):

Location:

CONTACT THE MONTANA NATURAL HERITAGE PROGRAM.

Element occurrence data:

CA. 180 PLANTS IN LESS THAN 0.2 MILE OF HABITAT. IN FULL FLOWER

8-14-97.

General site description:

BASE OF DITCH SLOPES IN HIGHWAY RIGHT OF WAY, WITH SEASONALLY

SATURATED SOILS IN VALLEY BOTTOMS. ASSOCIATED SPECIES INCLUDE AGROSTIS STOLONIFERA, EQUISETUM LAEVIGATUM, POA PRATENSIS, FESTUCA ELATIOR, AND HABENARIA HYPERBOREA.

Land owner/manager:

STATE LAND - UNDESIGNATED

Comments :

THE LOCAI SURVEY HAS NOT BEEN EXHAUSTIVE, BUT THERE ARE NO DIRECT CONNECTIONS BETWEEN THE OCCUPIED ROAD DITCH AND POTENTIAL NATURAL HABITAT. ROAD DITCH SEGMENTS TO THE NORTH, SOUTH, AND OPPOSITE SIDE OF THE HIGHWAY HAVE BEEN SURVEYED AND RULED OUT.

Information source: HEIDEL, BONNIE. [BOTANIST] MONTANA NATURAL HERITAGE PROGRAM, 1515 EAST SIXTH AVENUE, P.O. BOX 201800, HELENA, MT 59620-1800. WORK: 406/444-3009.

Specimens : 


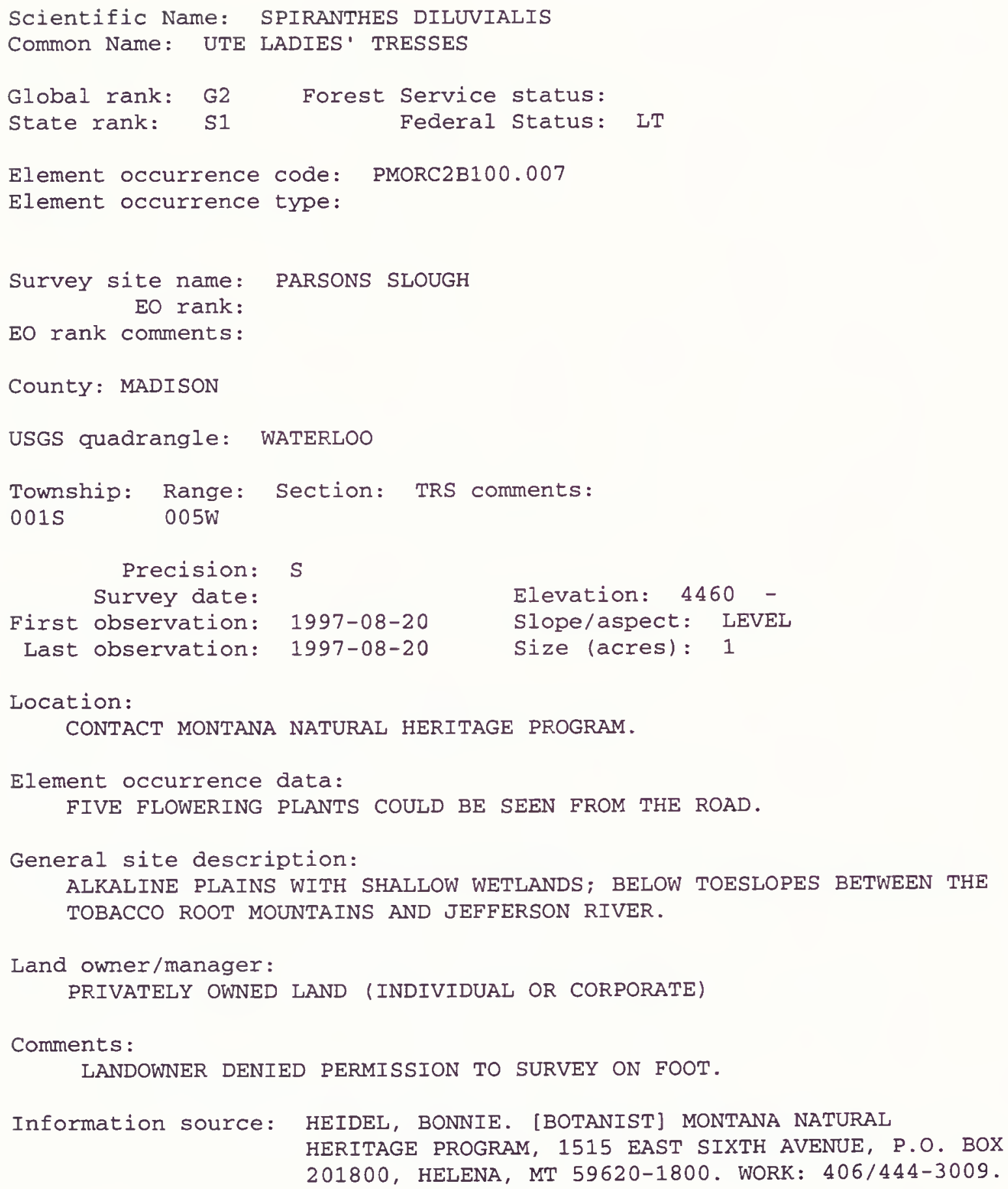

Specimens : 
Scientific Name: SPIRANTHES DILUVIALIS

Common Name: UTE LADIES' TRESSES

Global rank: G2

state rank: $\mathrm{S1}$

Forest Service status:

Federal Status: LT

Element occurrence code: PMORC2B100.008

Element occurrence type:

Survey site name: BULLRUN CREEK

EO rank:

EO rank comments:

County: GALLATIN

USGS quadrangle: NIXON GULCH

Township: Range: Section: TRS comments:

002N O04E

Precision: $M$

Survey date:

First observation: 1997-08-28 Slope/aspect:

Last observation: 1997-08-28 Size (acres): 1

Location:

CONTACT MONTANA NATURAI HERITAGE PROGRAM.

Element occurrence data:

SPARSE. ONLY 2 PLANTS FOUND IN ONE AREA. IN PEAK FLOWERING 8-28-97.

General site description:

WET SWALE IN SUBIRRIGATED WET MEADOW WITH HUMMOCKS BUT HIGH SPECIES DIVERSITY THROUGHOUT. BUFFALO BERRY ARE CONSPICUOUSLY COMMON THROUGHOUT THE SURROUNDING GALLATIN VALLEY BOTTOM. DOMINANTS INCLUDE MUHLENBERGIA RICHARDSONIS. COMMON ASSOCIATED SPECIES INCLUDE CAREX SCIRPOIDEA, DESCHAMPSIA CESPITOSA, AGROSTIS STOLONIFERA, CAREX PARRYANA AND ASTER FALCATUS. SOILS ARE SILTY CLAY LOAM.

Land owner/manager:

PRIVATELY OWNED LAND (INDIVIDUAL OR CORPORATE)

Comments :

FIELD SURVEY NOT SYSTEMATIC DUE TO LACK OF AERIAL PHOTOS.

Information source: HEIDEL, BONNIE. [BOTANIST] MONTANA NATURAL HERITAGE PROGRAM, 1515 EAST SIXTH AVENUE, P.O. BOX 201800, HELENA, MT 59620-1800. WORK: 406/444-3009.

Specimens : 


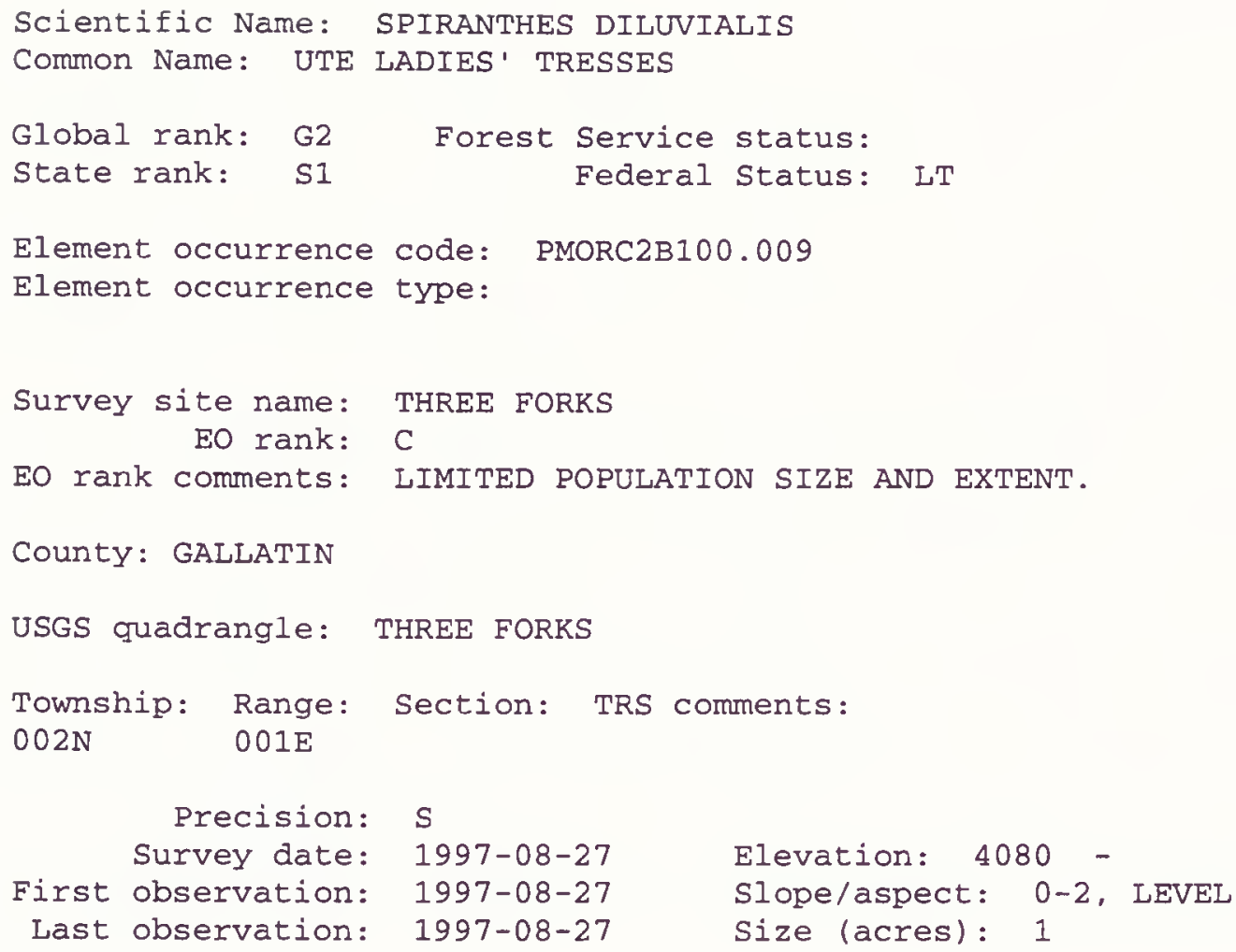

Comments:

Information source: HEIDEL, BONNIE. [BOTANIST] MONTANA NATURAL HERITAGE PROGRAM, 1515 EAST SIXTH AVENUE, P.O. BOX 201800, HELENA, MT 59620-1800. WORK: 406/444-3009.

Specimens : 
Scientific Name: SPIRANTHES DILUVIALIS

Common Name: UTE LADIES' TRESSES

Global rank: G2 Forest Service status:

State rank: S1 Federal status: LT

Element occurrence code: PMORC2B100.010

Element occurrence type:

Survey site name: THREE FORKS

EO rank: $\mathrm{CD}$

EO rank comments: SMALL POPULATION; DEGRADED HABITAT SETTING.

County: GALLATIN

USGS quadrangle: THREE FORKS

Township: Range: Section: TRS comments:

O02N $002 \mathrm{E}$

Precision: M

Survey date: 1997-08-27 Elevation: 4050 -

First observation: 1997-08-27 Slope/aspect: 0-2/EAST

Last observation: 1997-08-27 Size (acres): 1

Location:

CONTACT MONTANA NATURAL HERITAGE PROGRAM.

Element occurrence data:

15 PLANTS, IN PEAK FLOWERING 8-27-97.

General site description:

SEEPAGE ZONE ABOVE BACKWATER SLOUGH OF MADISON RIVER, BELOW A

TAMEGRASS MEADOW. SOILS ARE SILTY CLAY LOAM. COMMON SPECIES INCLUDE AGROSTIS STOLONIFERA, AGROPYRON CANINUM, EQUISETUM LAEVIGATUM, POTENTILLA ANSERINA, ASTER FALCATUS.

Land owner/manager:

PRIVATELY OWNED LAND (INDIVIDUAL OR CORPORATE)

Comments :

Information source: HEIDEL, BONNIE. [BOTANIST] MONTANA NATURAL HERITAGE PROGRAM, 1515 EAST SIXTH AVENUE, P.O. BOX 201800, HELENA, MT 59620-1800. WORK: 406/444-3009.

Specimens : 


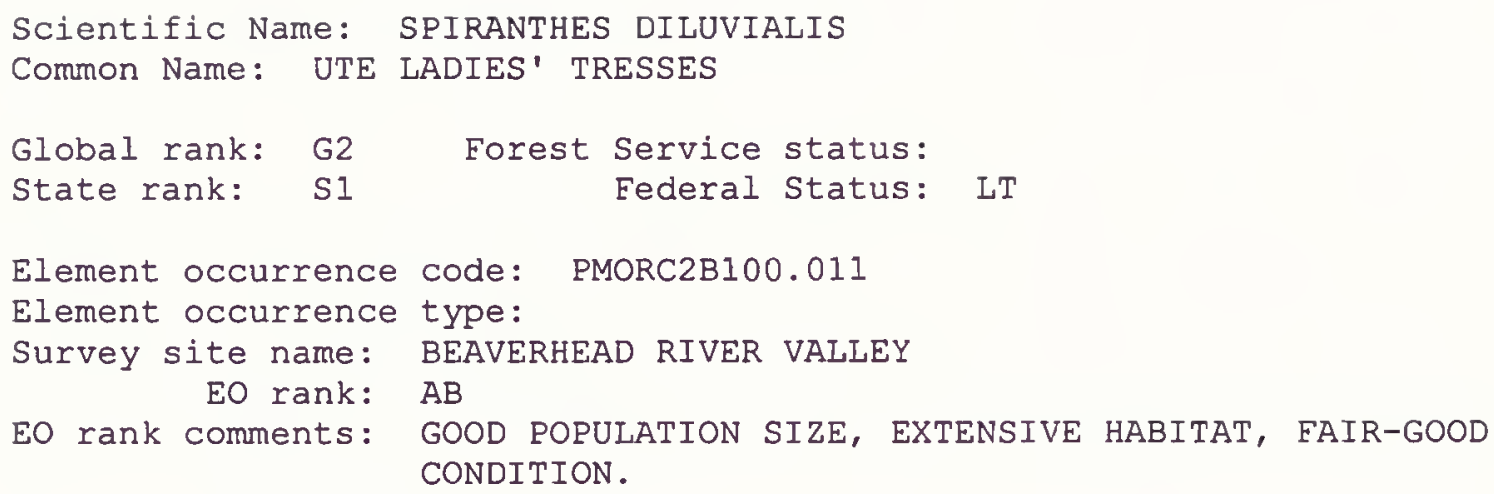

County: BEAVERHEAD

USGS quadrangle: GLEN SE

Township: Range: Section: TRS comments: 006S $008 \mathrm{~W}$

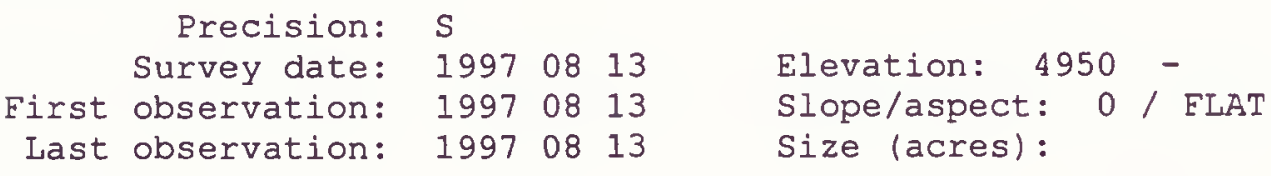

Comments :

Information source: HEIDEL, BONNIE. [BOTANIST] MONTANA NATURAL HERITAGE PROGRAM, 1515 EAST SIXTH AVENUE, P.O. BOX 201800, HELENA, MT 59620-1800. WORK: 406/444-3009.

Specimens: HEIDEL, B. (1600). 1997. MONT. 
Appendix B. Close-up and habitat photos

No. $\quad$ Slide

$1 \quad$ Spiranthes dilwvialis close-up

Photographer

Krisi DuBois

2 Spiranthes diluvialis whole plant

Bonnie Heidel

$3 \quad$ Spiranthes diluvialis vegetative plant

Bonnie Heidel

$4 \quad$ Spiranthes diluvialis vegetation microplot (Plot \#6)

Bonnie Heidel

$5 \quad$ Spiranthes diluvialis typical wet meadow habitat (EO\#004)

Bonnie Heidel

6 Spiranthes diluvialis habitat, early in growing season (6 June)

Bonnie Heidel

$7 \quad$ Spiranthes diluvialis habitat, extreme marl pool development;

Bonnie Heidel also part of the site of a recent wildfire

8 Typical surrounding upland habitat of Sporobolus airoides h.t.

Bonnie Heidel and abundant Shepherdia argentea and Astragalus robbinsii 



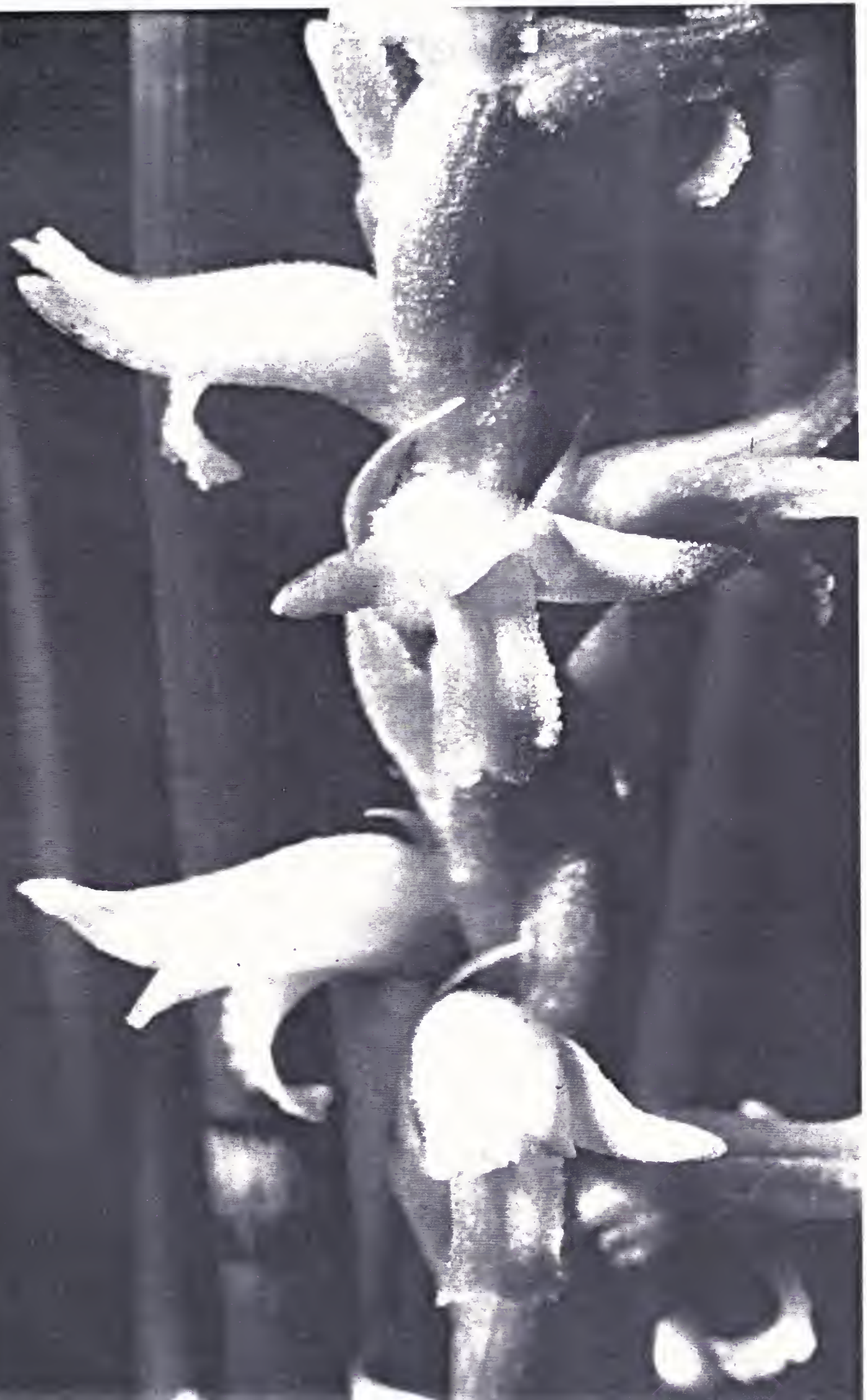



a

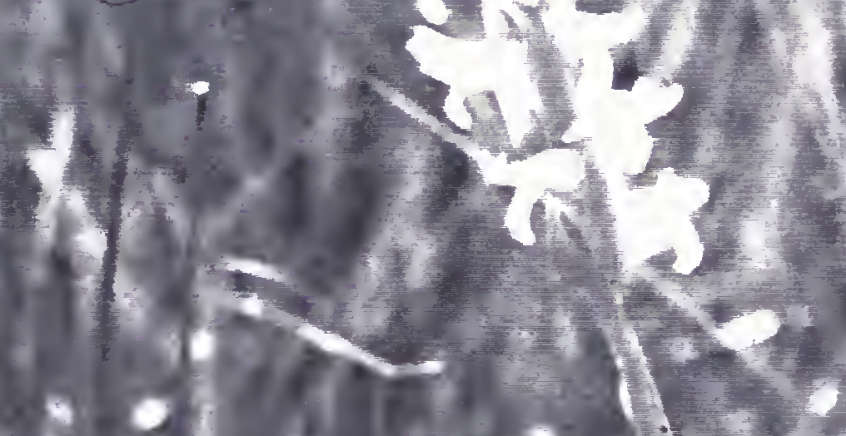

\section{$t^{\prime}$}

ysures:

a 90.

$12+2$

exp 1.1.

ger.

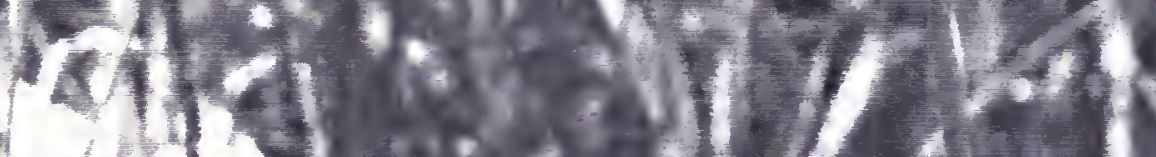

$x=7 \cdot \sqrt{2}, 4$

He.

2.

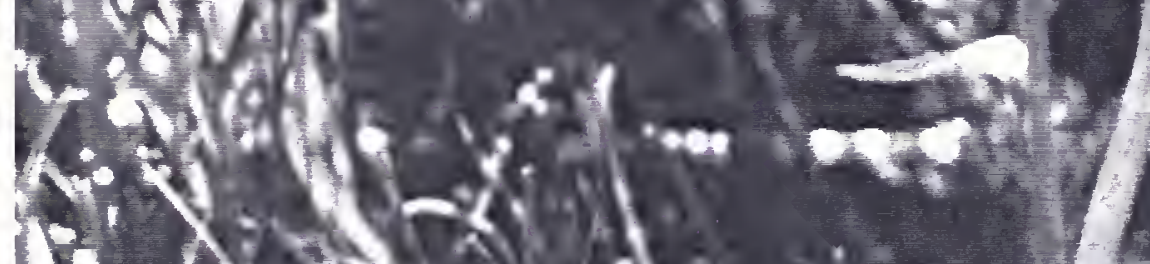

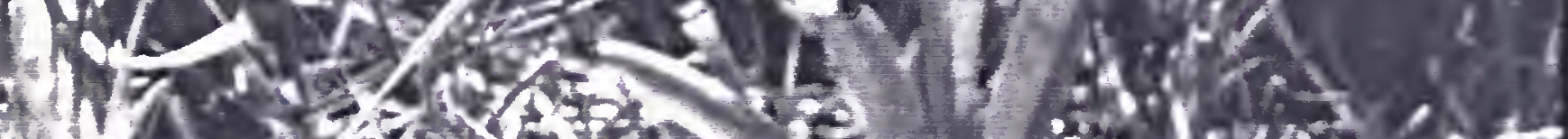

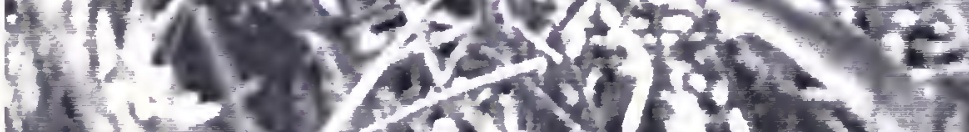
2. 20, $340=$ b.

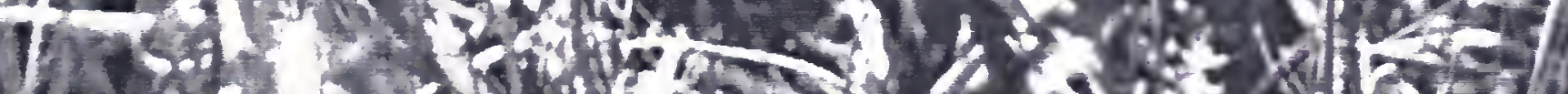

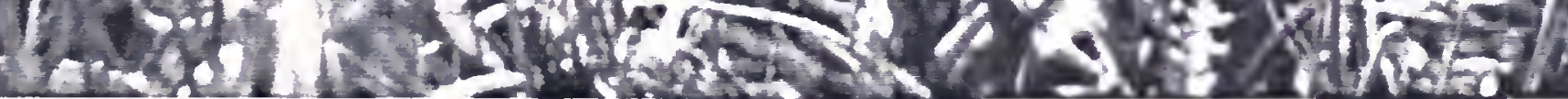




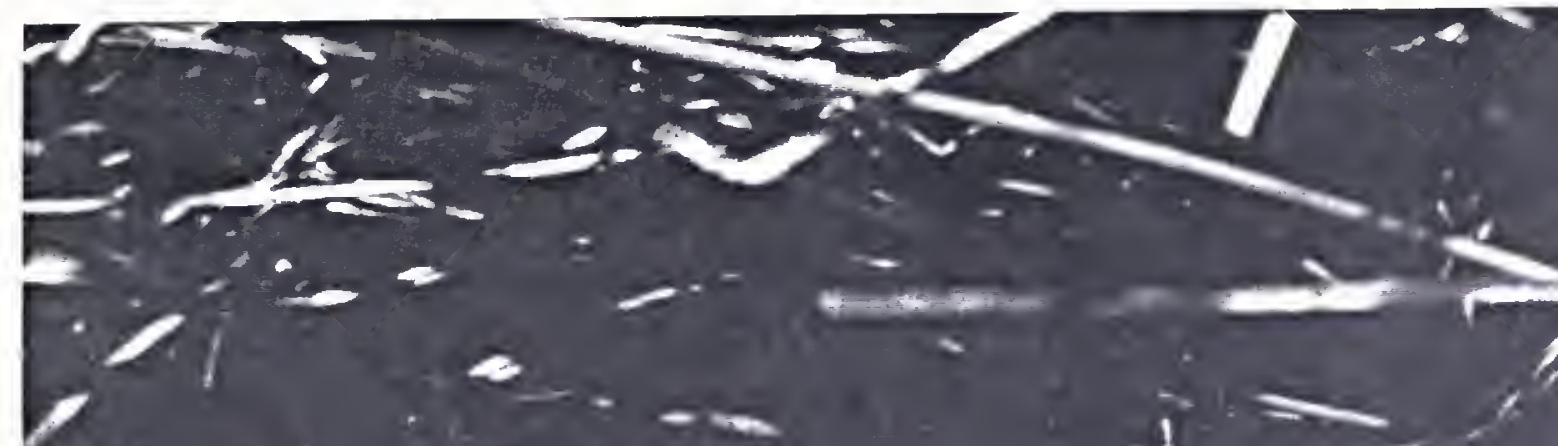

$\int_{-1}^{1} \sum_{-\infty}^{2}$

$12=$

$1=2$

\section{更}

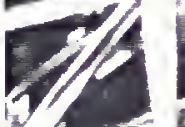

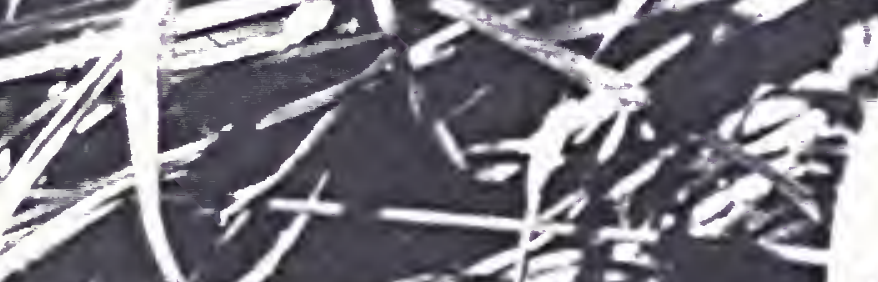

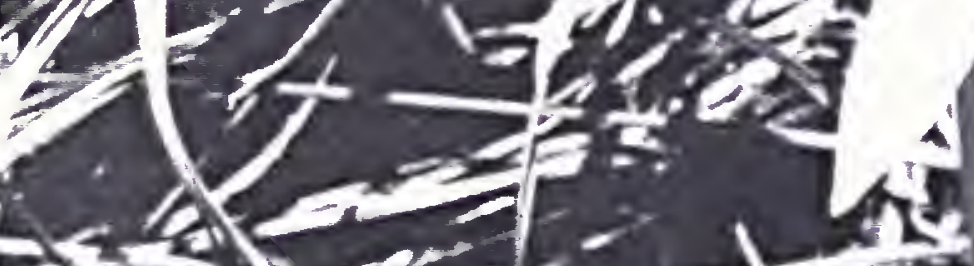

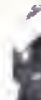

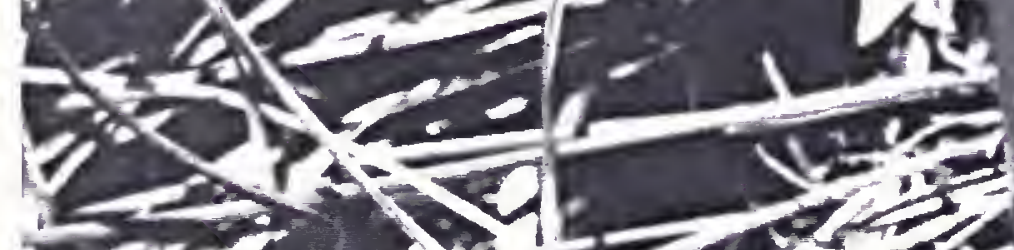
DE 1010 a $\quad$ is 1

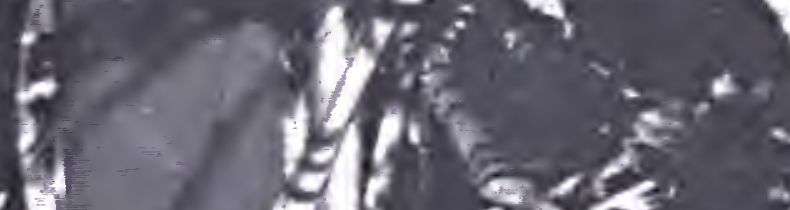
$=-\infty$
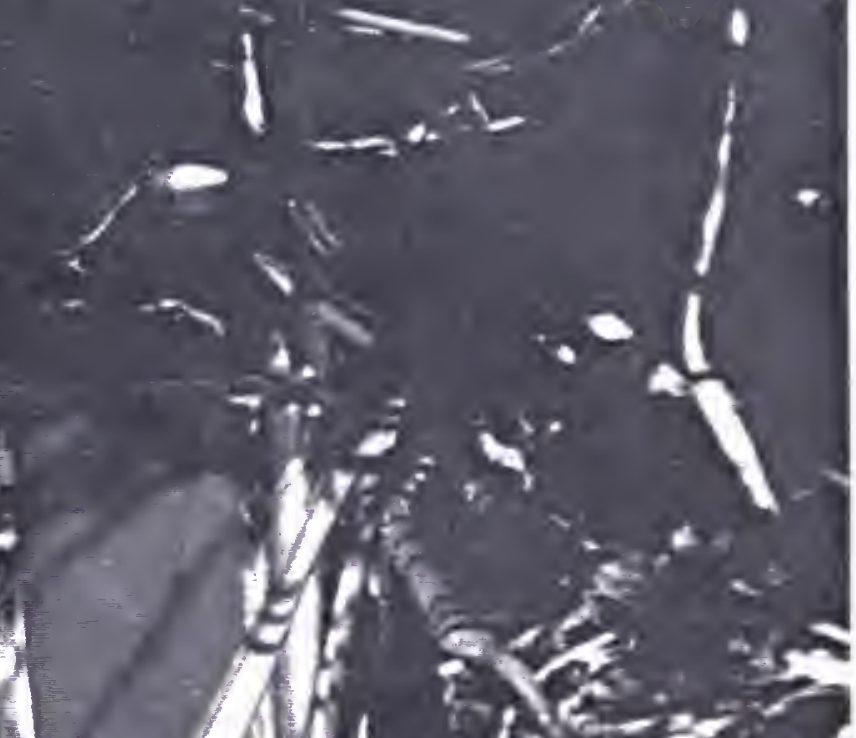

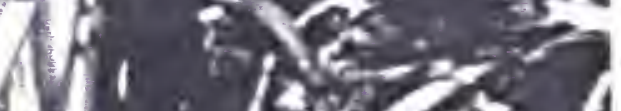
As: $: \int y+2$

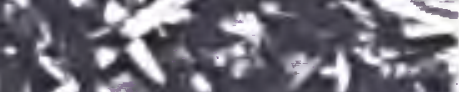
(1)

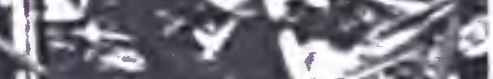
(1)

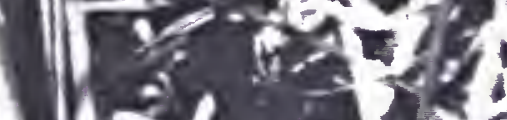
$\lim _{10} 10$

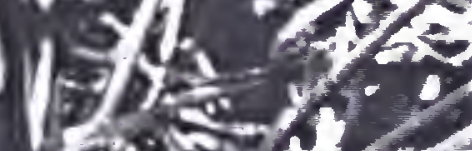
$30 \cos ^{2}+2$ (F) $2,-\infty, 1$

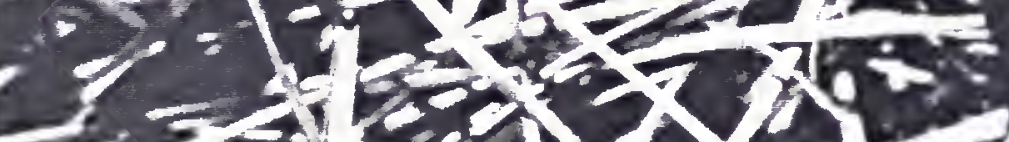

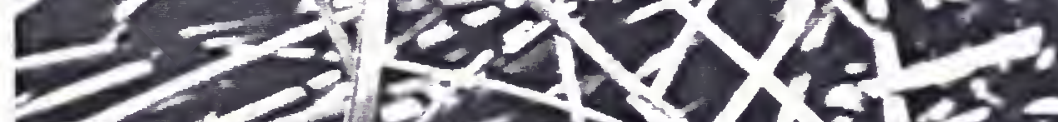
25.

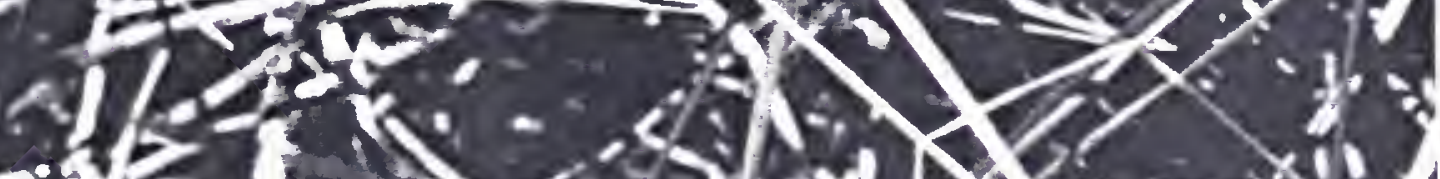

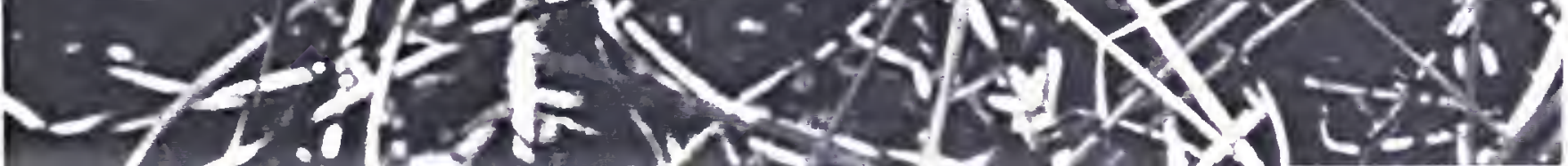



105075

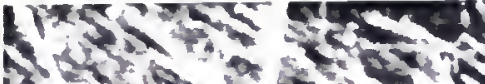

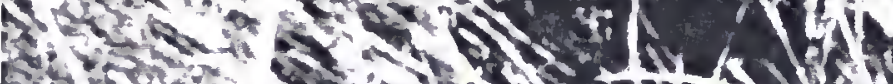

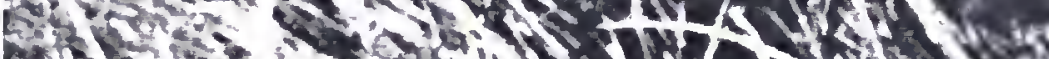

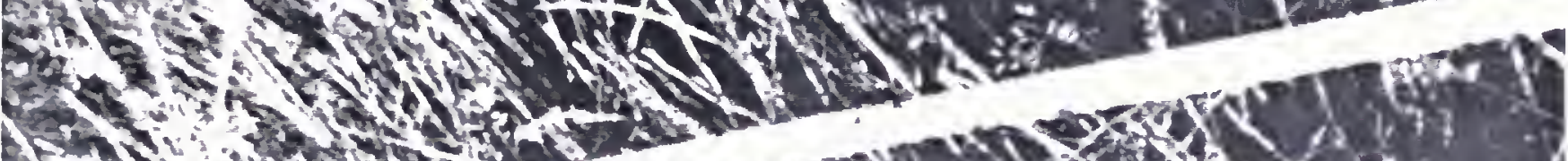

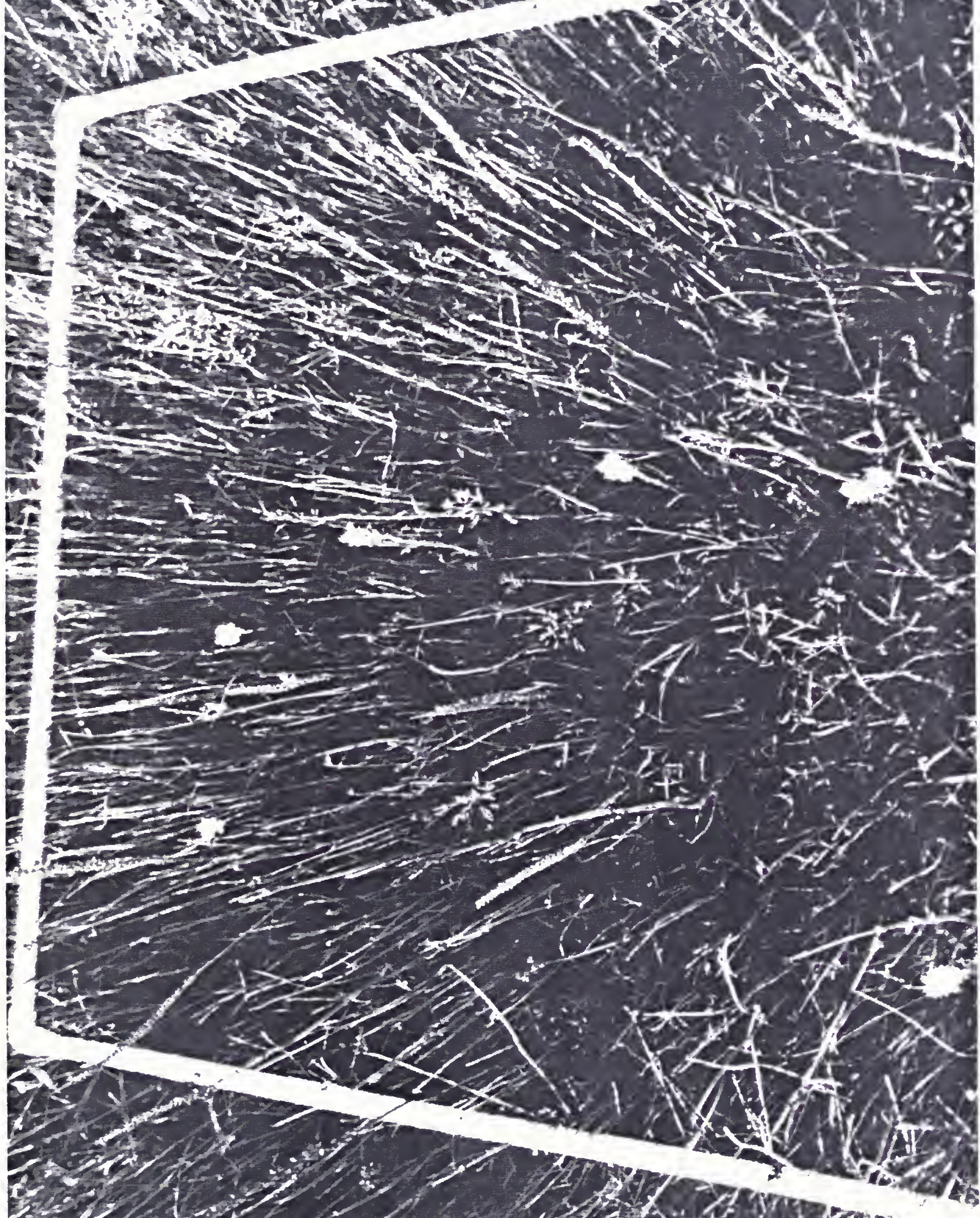

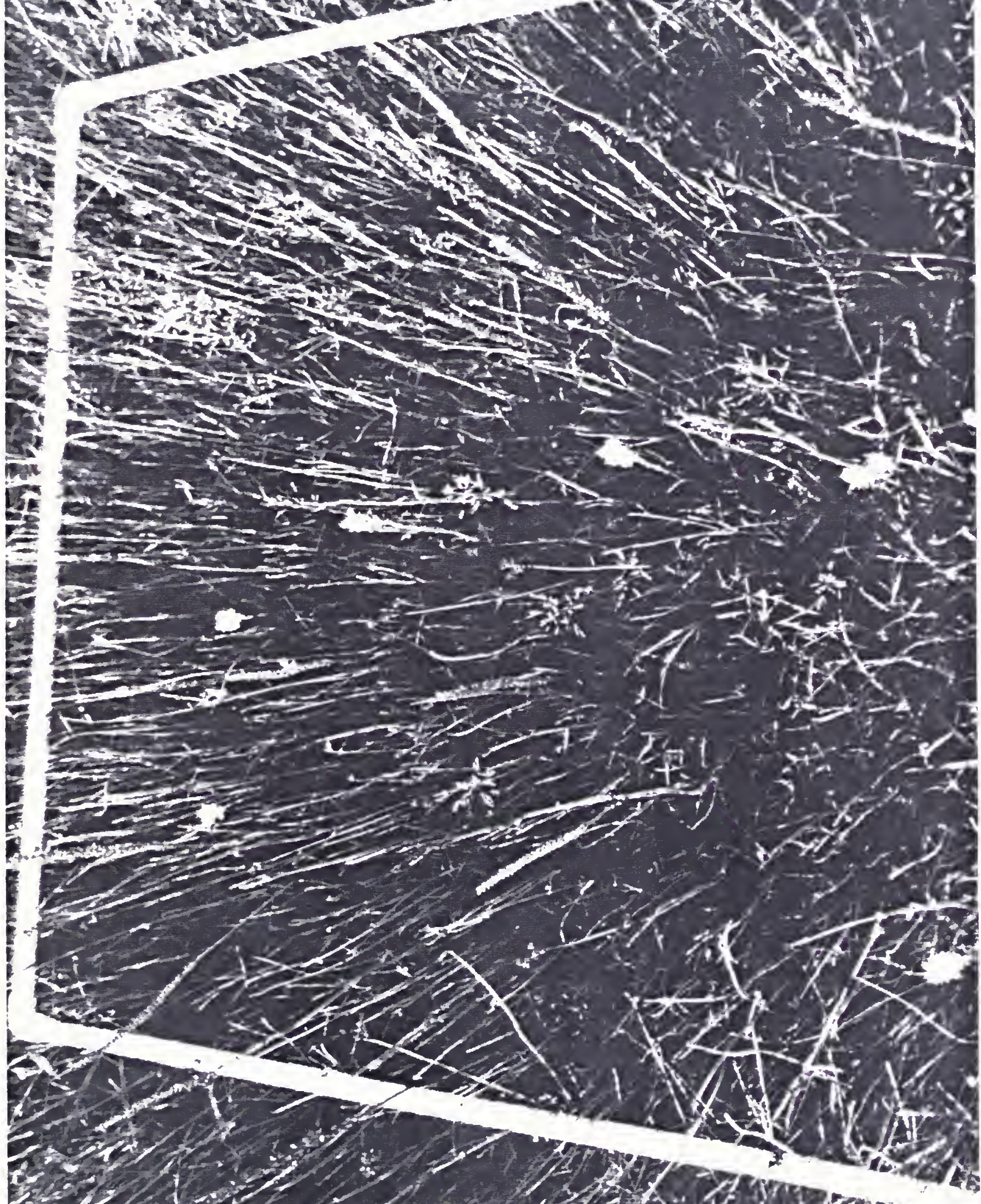

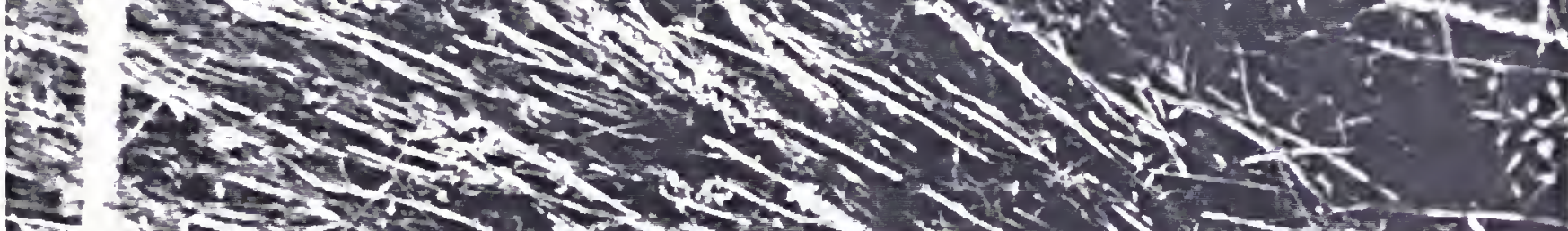





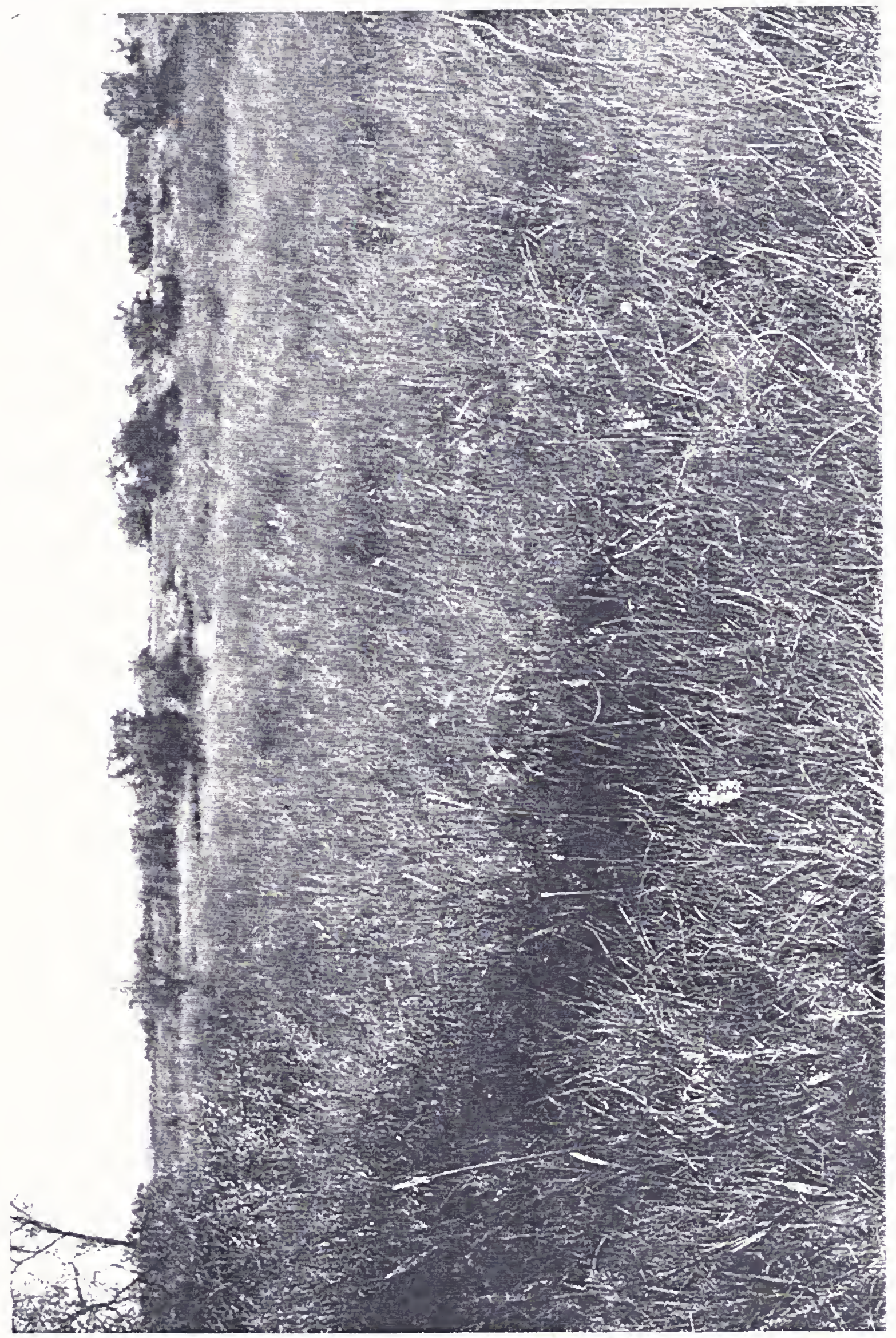




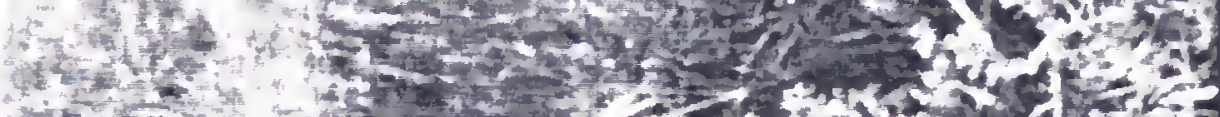

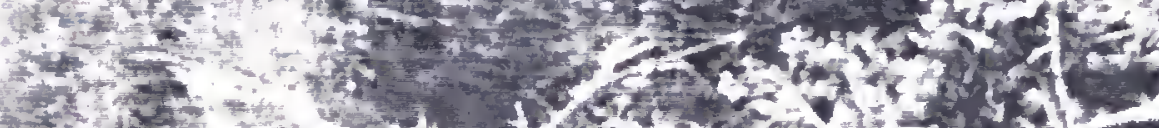

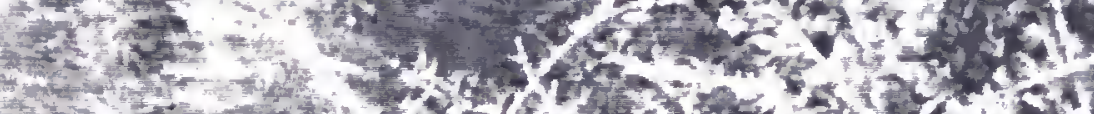

- D.t.2.

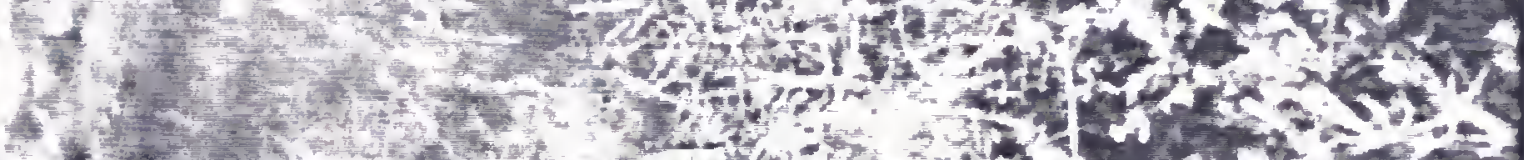

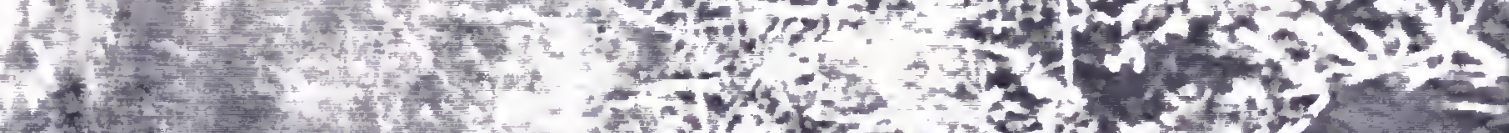

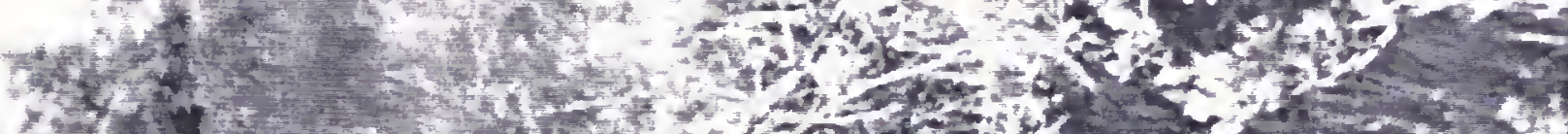

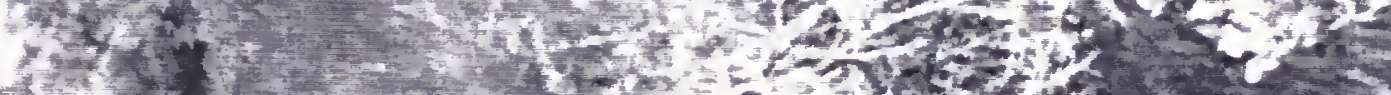

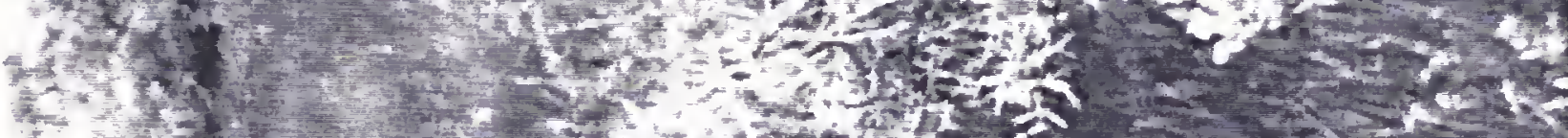

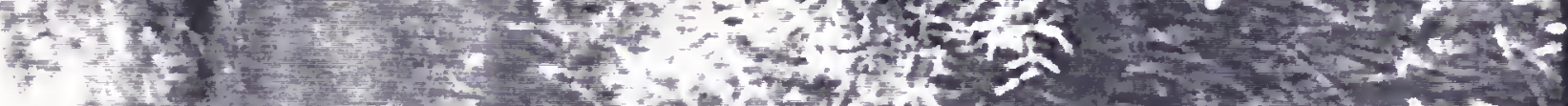

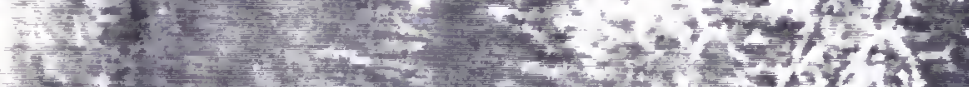

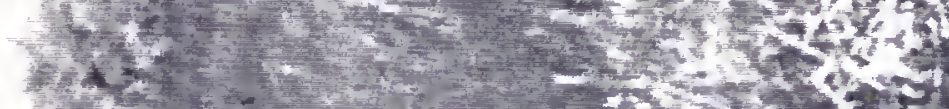
(1)

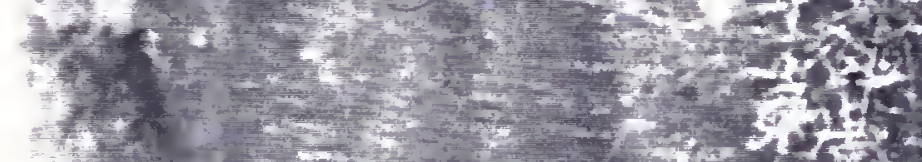

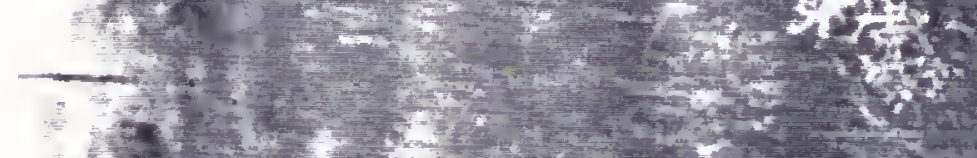
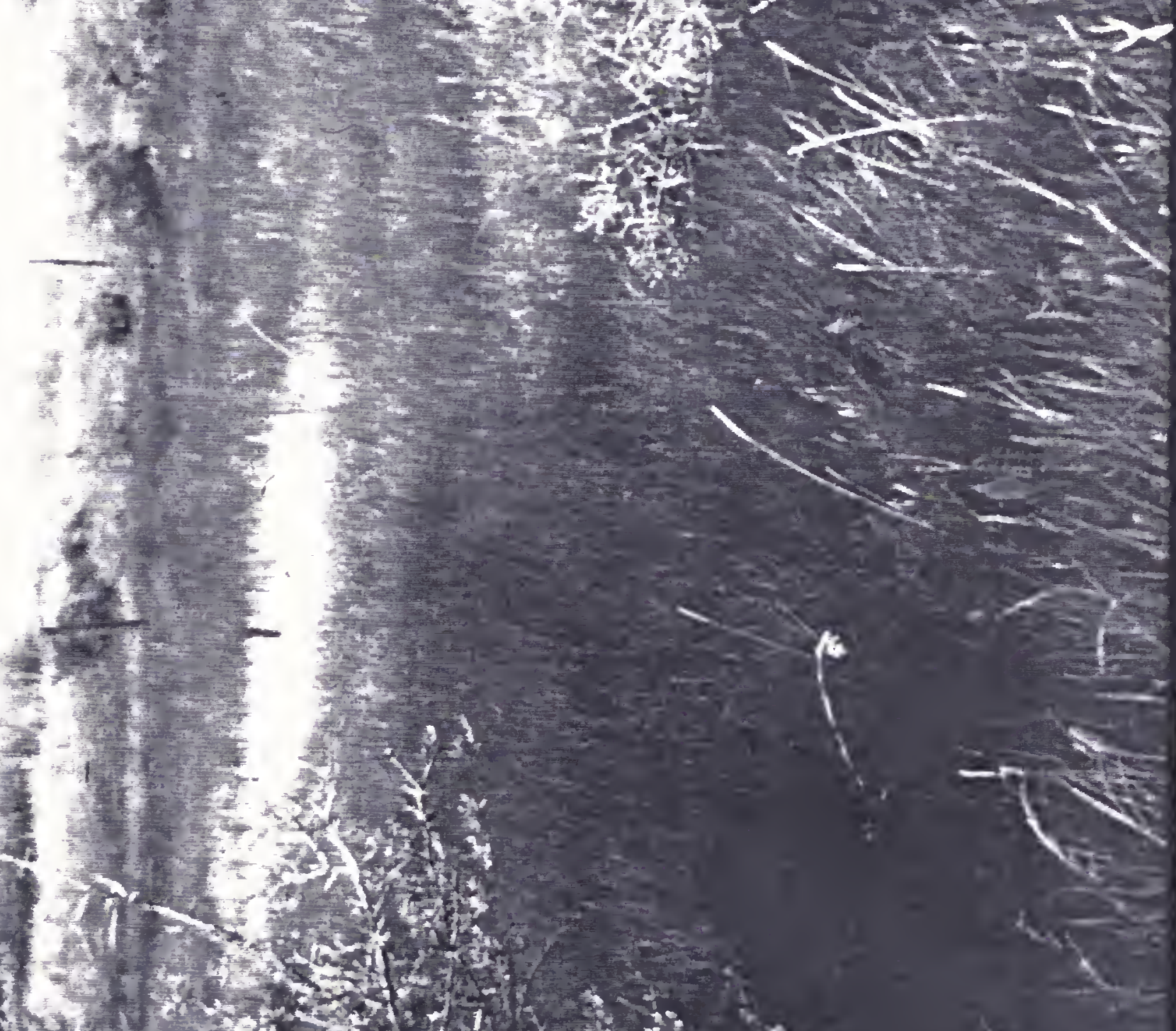

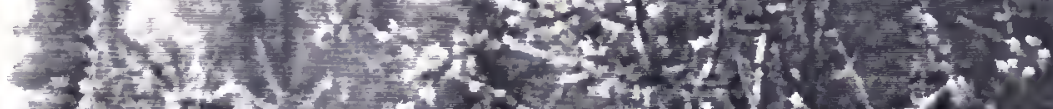

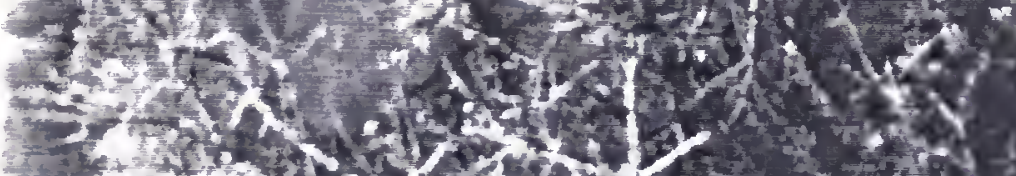

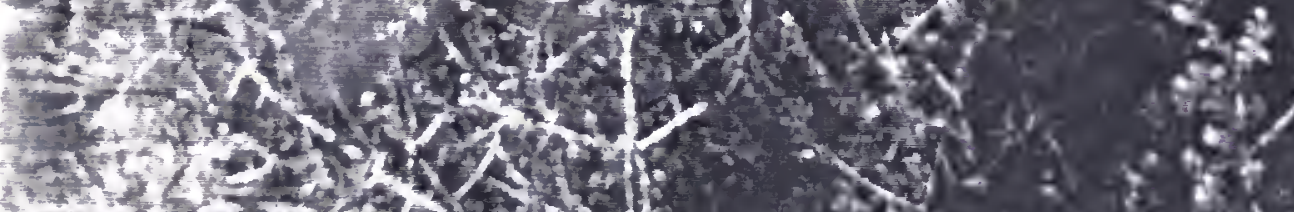

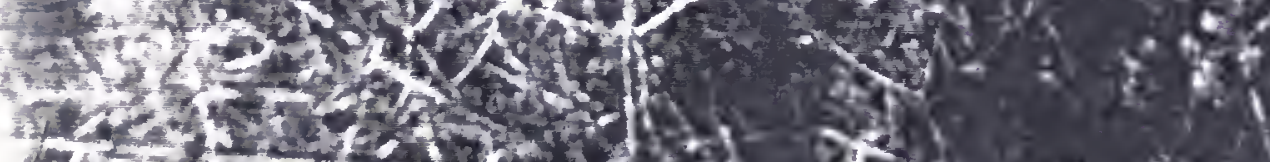

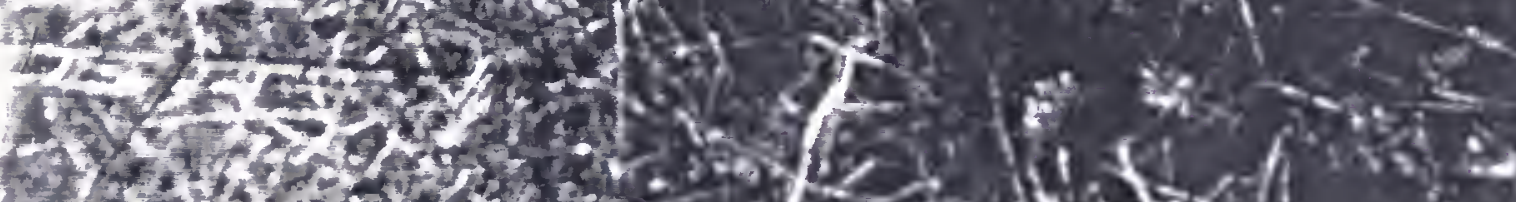

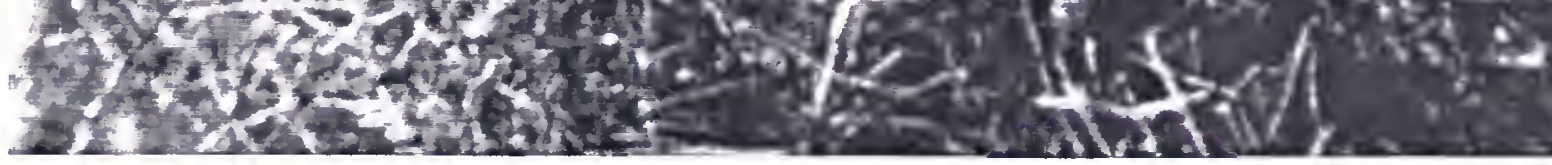





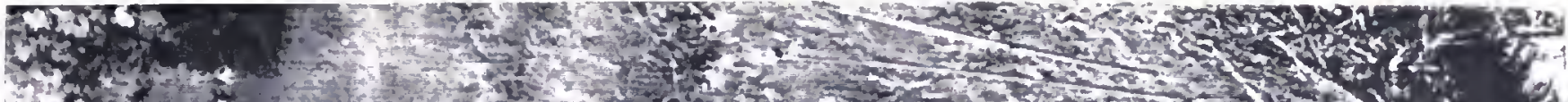

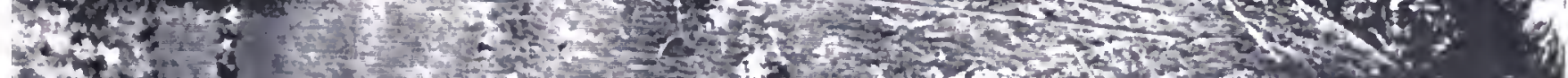

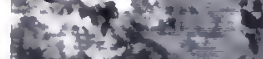

.

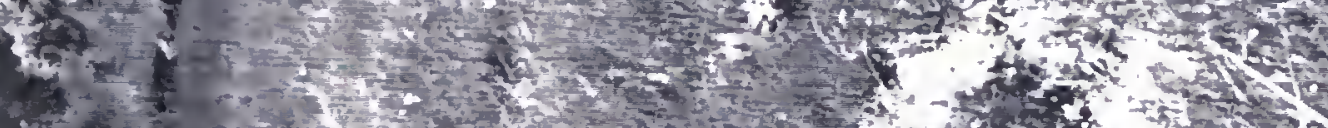

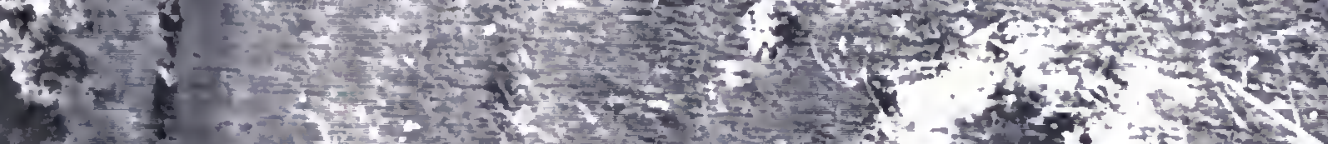

$2 x^{3}$,

(1)

(3)

H.

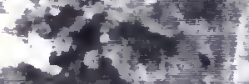

(3)

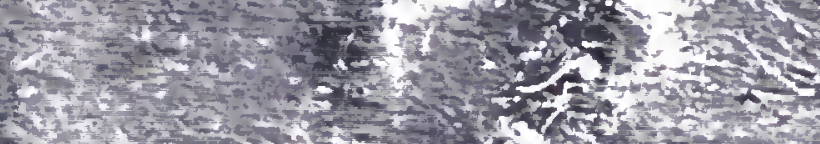

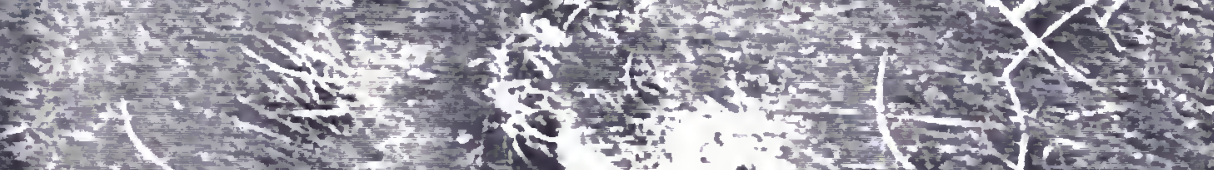

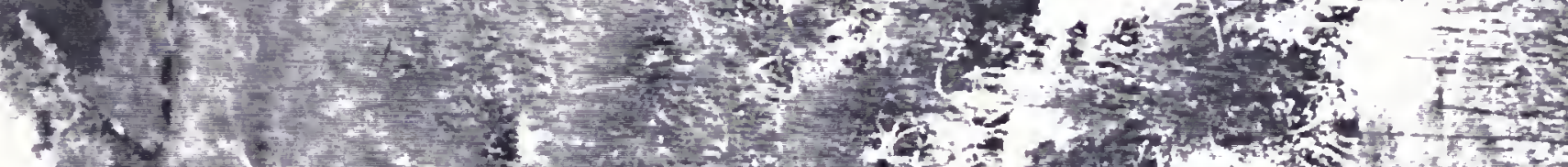

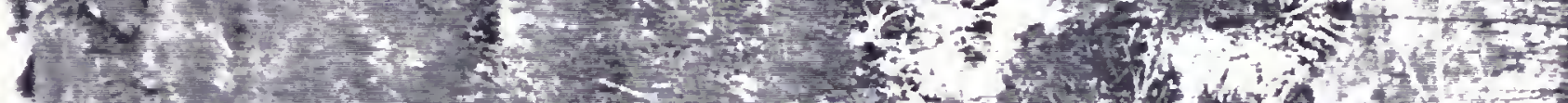

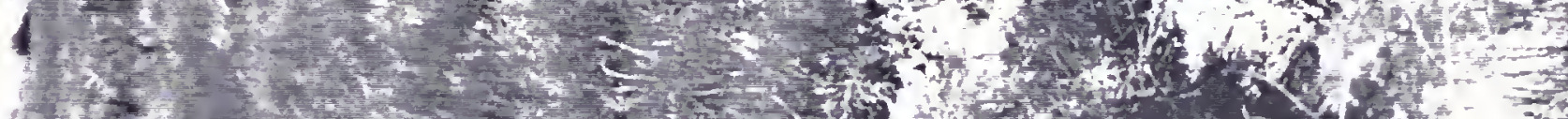

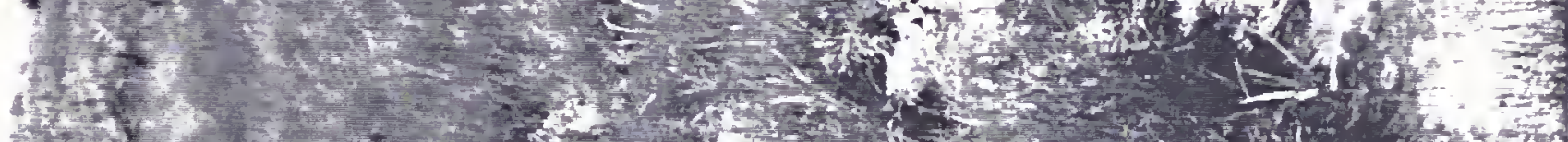
$14 y$
14

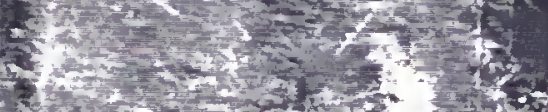

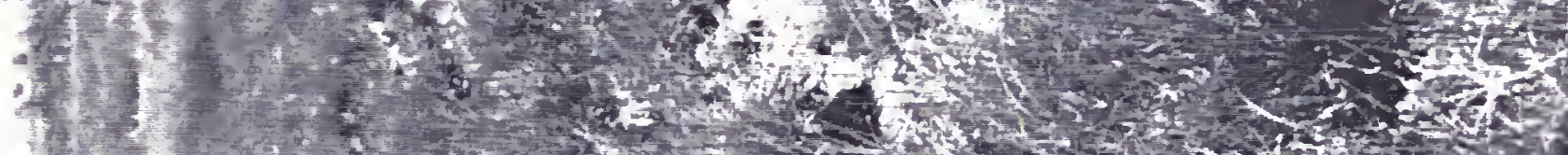

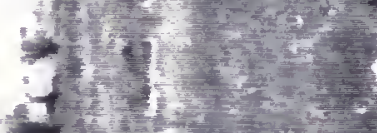

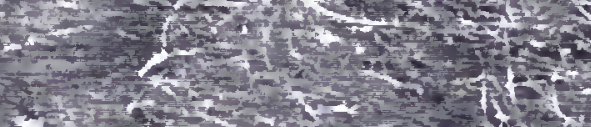

st

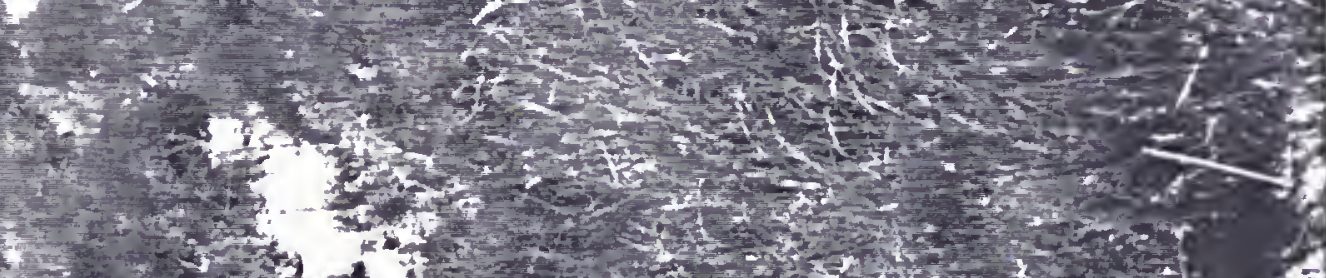

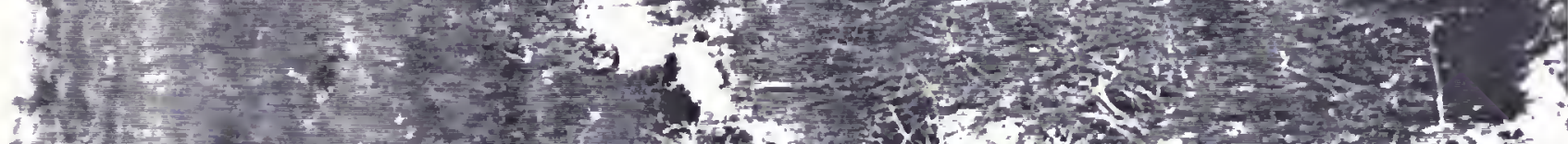

$x$ $x+3=2$

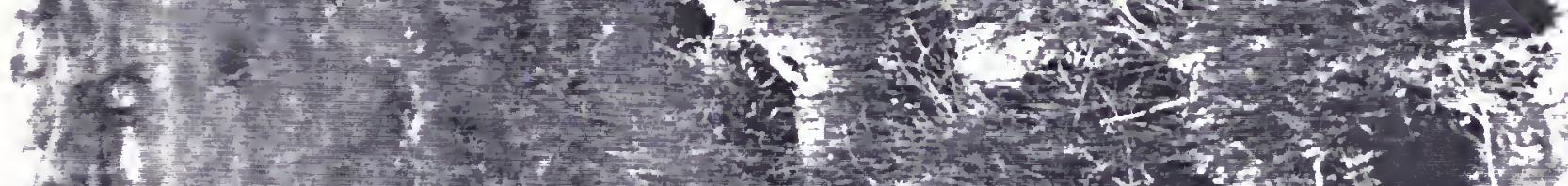

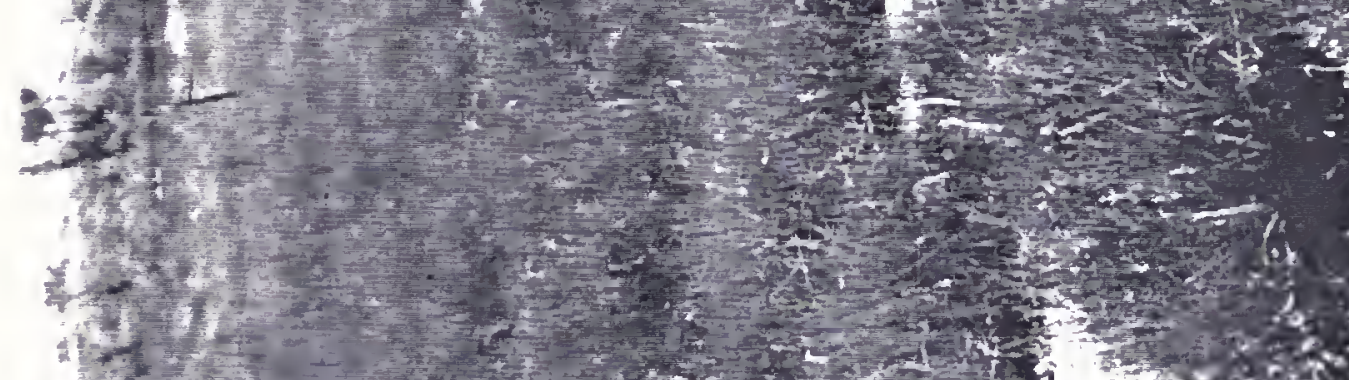

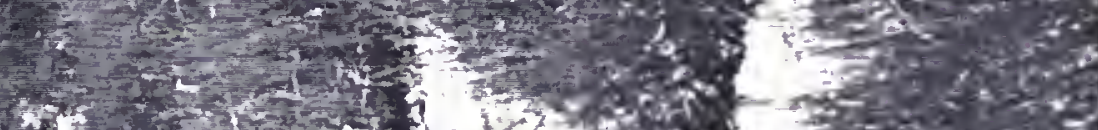
is

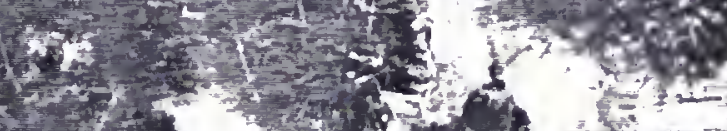
-

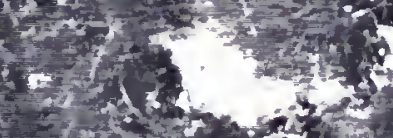

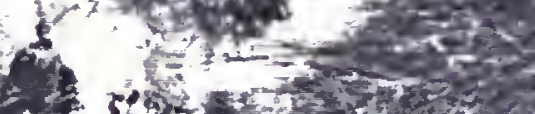

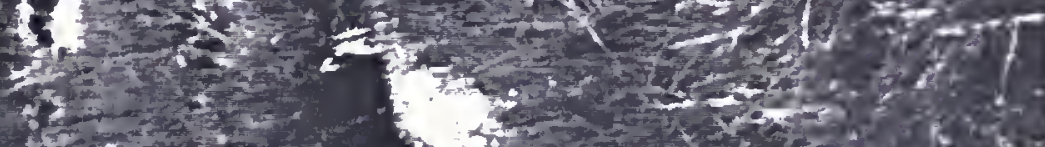





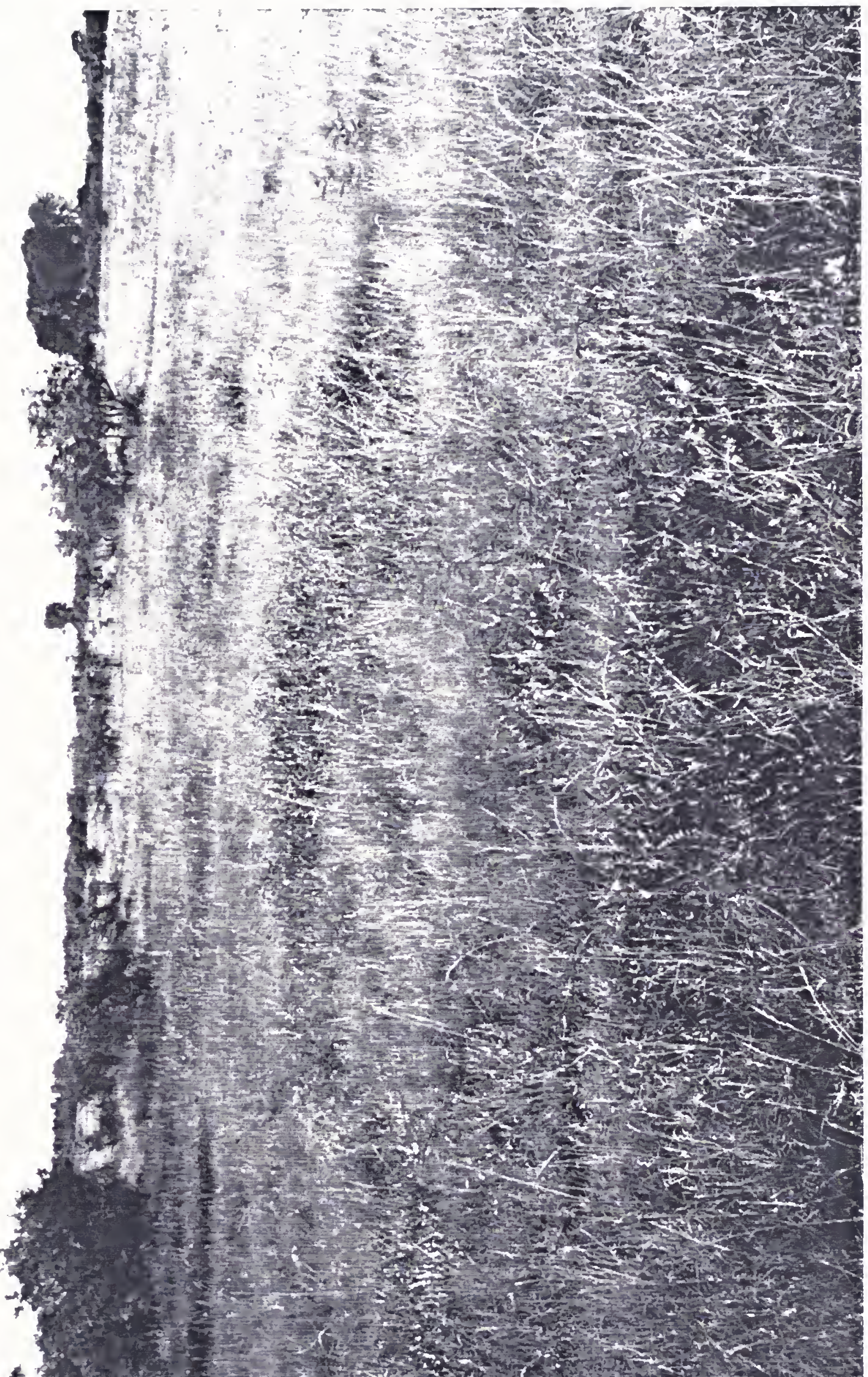

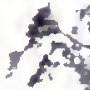



Appendix C. Species associated with Spiranthes diluvialis in Montana and rangewide

$$
\begin{aligned}
& \begin{array}{lllllll}
\mathrm{MT}^{1} & \mathrm{ID}^{2} & \mathrm{NE}^{3} & \mathrm{CO}^{4} & \mathrm{UT}^{5} & \mathrm{UT}^{6} & \mathrm{WY}^{7}
\end{array} \\
& \text { (Uinta) (Wasatch) }
\end{aligned}
$$

(Note: Exotic species are asterisked. The preliminary WA information is not included.)

Scientific name

Achillea millefolium

Agalinus tenuifolia

Agrostis stolonifera*

Alisma trivale

Alnus incana

Ambrosia psilostachya

Ambrosia trifida

Andropogon gerardii

Artemisia ludoviciana

Asclepias incarnata

Asclepias speciosa

Asclepias viridiflora

Aster ascendens

Aster brachyactis

Aster canadensis

$\begin{array}{llllll} & & x & & & \\ & & x & x & & \\ & x & x & x & x & \\ & & & & & \end{array}$

Aster chilensis

Aster ericoides

Aster falcatus

Aster hesperius

Aster junciformis?

$\mathrm{x}$

$\mathrm{x}$

Aster lanceolatus

Aster occidentalis

Aster pansus

Aster praealtus

Astragalus cicer

$\begin{array}{ll}\mathrm{X} & \\ \mathrm{X} & \mathrm{x} \\ \mathrm{x} & \\ \mathrm{X} & \mathrm{x} \\ \mathrm{x} & \\ \mathrm{X} & \end{array}$

$\mathrm{x}$
$\mathrm{x}$

$\begin{array}{lllll} & \mathrm{x} & & \\ \mathrm{x} & \mathrm{x} & \mathrm{x} & \mathrm{x} \\ \mathrm{x} & & \mathrm{x} & \mathrm{x} \\ & & \mathrm{x} & & \\ & & & \\ & & & \\ & & & \\ & \mathrm{x} & & \\ & \mathrm{x} & & \\ & & \end{array}$

${ }^{1}$ Unpublished information collected in the course of this survey.

${ }^{2}$ Unpublished information collected in 1996 and 1997 field surveys (Idaho Conservation Data Center 1996, 1997).

${ }^{3}$ From Hazlett 1996; and Hildebrand 1998 (excluding the terrestrial and deepwater species)

${ }^{4}$ From Arft (1995a) and U.S. Fish and Wildlife Service 1995b

${ }^{5}$ From U.S. Fish and Wildlife Service 1995b.

${ }^{6}$ From U.S. Fish and Wildlife Service 1995 b.

${ }^{7}$ From Hazlett 1997 
Astragalus robbinsii

Atriplex subspicata

Berula erecta

Betula occidentalis

Bidens cernua

Bidens comosa

Bidens frondosa

Bromis inermis*

Calamagrostis canadensis

Calamagrostis inexpansa

Calamagrostis stricta

Calamagrostis spp.

Carex aurea

Carex brevior

Carex comosa

Carex douglasii

Carex emoryi

Carex lanuginosa

Carex nebrascensis

Carex parryana

Crex pellita

Carex praegracilis

Carex prairea

Carex scirpiformis

Carex scoparia

Carex simulata

Carex vulpinoidea

Carex spp.

Castilleja exilis

Catabrosa aquatica

Centaurea maculosa*

Cerastium vulgatum

Chenopodium album*

Chenopodium rubrum

Circaea lutea

Cirsium arvense*

Cirsium flodmanii

Cirsium spp.

Cornus sericea

Crepis runcinata

Cuscuta indecora

Cyperus diandrus

Dactylis glomerata*

Descurainia sophia*

Dianthus armeria*
MT ID NE CO UT UT WY

(Uinta) (Wasatch)
$\mathrm{X}$ $x$

$\mathrm{x}$

$\mathrm{x} \quad \mathrm{X}$

$\mathrm{x}$

$\mathrm{x}$

$\mathrm{x}$

$\mathrm{x}$

$\mathrm{x}$

$\mathrm{x} \quad \mathrm{x}$

$x$

$\mathrm{x}$

$x$

$x$
$x$
$x$

$\mathrm{x}$

$\mathrm{X}$

$\mathbf{x}$

$\mathrm{x}$

$\mathrm{x} \quad \mathrm{x}$

$\mathrm{x}$

$x$

$\mathrm{x} \quad \mathrm{x}$

$\mathrm{x}$

$\mathrm{x}$

$\mathrm{x}$

$\mathrm{x}$

$\mathrm{x}$

$\mathrm{X}$

$\mathrm{x} \quad \mathrm{x}$

$\mathrm{x}$

$\mathrm{x}$

$\mathrm{X}$

$\mathrm{x}$

$\mathrm{x}$

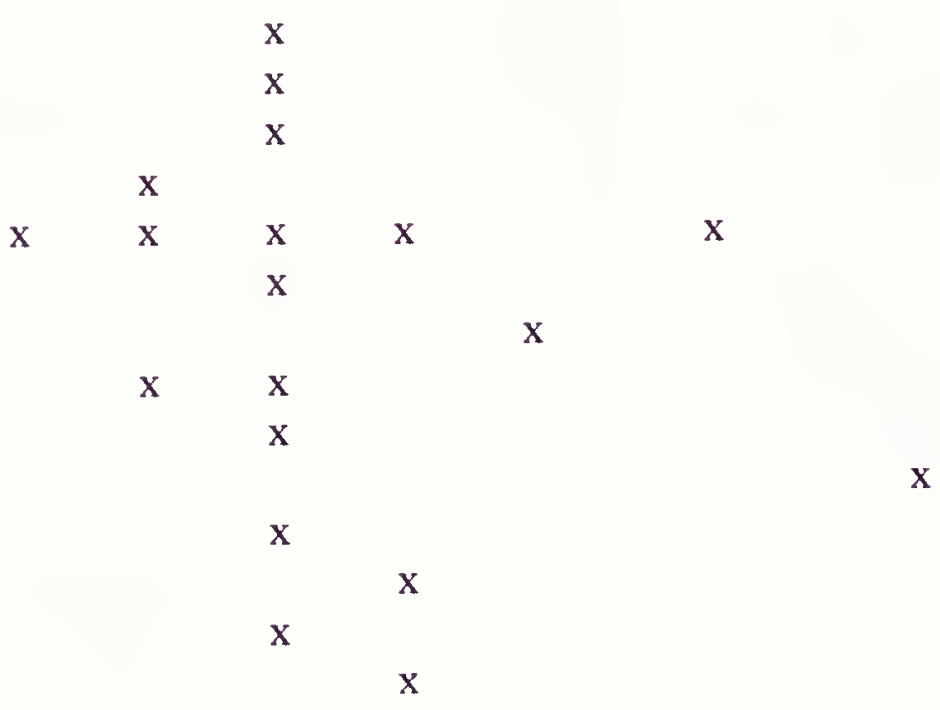


Dodecatheon pulchellum

Elaeagnus angustifolia*

Elaeagnus commutata

Eleocharis acicularis

Eleocharis elliptica

Eleocharis erythropoda

Eleocharis palustris

Eleocharis pauciflora

Eleocharis parvula

Eleocharis rostellata

Elymus canadensis

Elymus repens*

Elymus trachycalus

Elymus varnensis*

Epilobium coloratum

Epilobium leptophyllum

Epilobium palustre

Epipactis gigantea

Equisetum arvense

Equisetum hyemale

Equisetum laevigatum

Equisetum variegatum

Equisetum spp.

Erigeron lonchophyllus

Eupatorium maculatum

Euphorbia esula*

Eustoma grandiflorum

Euthamnia gymnospermoides

Festuca arundinacea*

Festuca pratensis*

Galium boreale

Galium trifidum

Gaura parviflora

Gentiana andrewsii

Gentianella amarella

Geum canadense

Glaux maritima

Glyceria grandis

Glyceria striata

Glycyrrhiza lepidota

Habenaria hyperborea

Habenaria unalaskensis

Helianthus maximilianii

Helianthus nuttallii

(Uinta) (Wasatch)

$\mathrm{x}$

$\mathrm{X}$

$\mathrm{x}$

$\mathrm{X}$

$\mathrm{x}$

$\mathrm{X}$

$\mathrm{x}$

$\mathrm{x}$

$\mathrm{x} \quad \mathrm{x}$

$\mathrm{X}$

$\mathrm{X}$

$\mathrm{x}$

$\mathrm{X}$

$\mathrm{X}$

$\mathrm{X}$

$\mathrm{X}$

$\mathrm{X}$

$\mathrm{X}$

$\mathrm{X}$

$\mathrm{x} \quad \mathrm{x}$

$\mathrm{x}$

$\mathrm{X}$

X

X $\quad \mathrm{X}$

$\mathrm{X}$

$\mathrm{x}$

$\mathrm{X}$

$\mathrm{x}$
$\mathrm{X}$

$\mathrm{X}$

$\mathrm{X}$ X

X

$\mathrm{X}$

$\mathrm{X}$

X

$\mathrm{X}$

$\mathrm{X}$

$\mathrm{X}$

$\mathrm{X}$

X

$\mathrm{X}$

$\mathrm{x}$

$\mathrm{X}$

$\mathrm{X}$

$\mathrm{X}$

$\mathrm{x} \quad \mathrm{x}$

$\mathrm{X} \quad \mathrm{X}$

$\mathrm{X}$

X

$\mathrm{X}$ 
ID NE CO UT UT WY

Helianthus petiolaris (Uinta) (Wasatch)

Hippuris vulgaris

Hordeum jubatum

Impatiens capensis

Iris pseudacorus

Iva axillaris

Juncus balticus

Juncus bufonis

Juncus casteanus

Juncus confusus

Juncus dudleyi

Juncus ensifolius

Juncus longistylis

Juncus marginatus

Juncus nevadensis

Juncus nodosus

$\mathbf{X}$

Juncus tenuis

Juncus torreyi

Juncus spp.

Lactuca pulchella

Liatris lancifolia

Linum perenne

Linum rigidum

Lobelia siphilitica

Lotus tenuis*

Lupinus plattensis

Lycopus americanus

Lycopus asper $\mathrm{x}$

Machaeranthera tanacetifolia

Medicago sativa*

Melilotus alba*

$\mathrm{x}$

Melilotus officinalis*

$\mathrm{X}$

$\mathrm{x} \quad \mathrm{x} \quad \mathrm{x}$

$\mathrm{x}$

$\mathrm{X}$

$\mathrm{x}$

$\begin{array}{ccc} & & \mathrm{x} \\ & \mathrm{x} & \mathrm{x} \\ \mathrm{x} & & \\ \mathrm{X} & \mathrm{x} & \mathrm{x} \\ & \mathrm{x} & \end{array}$

$\mathrm{x}$

$\mathrm{X}$

$\mathrm{x}$

$\mathrm{x} \quad \mathrm{x}$

Melilotus spp.*

Mentha arvensis

Mimulus glabratus

Mirabilis hirsuta

Muhlenbergia asperifolia $\quad \mathrm{x}$

Muhlenbergia filiformis $\mathrm{x}$

Muhlenbergia glomerata

Muhlenbergia mexicana

Muhlenbergia racemosa

Muhlenbergia richardsonis $\mathrm{x}$

Musineon tenuifolium

$\mathrm{x}$

$\mathrm{x}$

$\mathrm{x}$

$x$

$\mathrm{X}$

X

$\mathrm{X}$

$\mathrm{x}$

$\mathrm{x}$

$\mathrm{x}$

$\mathrm{x}$

$\mathrm{x}$

$\mathrm{x}$

$\mathrm{X}$

$\mathrm{x}$

$\mathrm{x}$

$\mathrm{x}$

$\mathrm{X}$

$\mathrm{x}$

$\mathrm{x}$

$\mathrm{x}$

$\mathrm{x}$

$\mathrm{x}$

$\mathrm{x} \quad \mathrm{x}$

$\mathrm{X}$

$\mathrm{x}$

$\mathrm{x}$

Myosotis scorpioides

Nasturtium officinale 
UT UT WY

Oenothera elata

(Uinta) (Wasatch)

Orobanche multiflora

$\mathrm{x}$

Orthocarpus luteus

Panicum capillare

Panicum virgatum

Parietaria pensylvanica

Parnassia fimbriata

$\mathrm{x}$

Parnassia palustris

Pascopyrum smithii

Pedicularis crenulata

Phalaris arundinacea*

Phleum pratense*

Phlox kelseyi var. kelseyi $\quad \mathrm{x}$

Pilea fontana

Plantago eriopoda

Plantago lanceolata

Plantago major*

Platanthera dilatata

Poa arida

Poa pratensis*

Polygonum amphibium

Polygonum coccineum

Polygonum lapathifolium

Polygonum pensulvanicum

Polygonum persicaria

Polygonum ramosissimum

Polygonum sagittatum

Polypogon monspeliensis

Populus angustifolia

Populus deltoides

Potentilla anserina

Potentilla arguta

Potentilla gracilis

Potentilla pensylvanica

Primula incana

Prunella vulgaris*

Prunus virginiana

Ranunculus cymbalaria

Ranunculus longirostris

$\mathrm{x}$

$\mathrm{x}$

$\mathrm{x} \quad \mathrm{x}$

$\mathrm{X} \quad \mathrm{X}$

$\mathrm{x}$

$\mathrm{x}$

$\mathrm{x}$

Ranunculus populago

Ranuculus spp.

Ratibida columnifera

Rosa woodsii

Rudbeckia hirta

Rumex mexicanus $\mathrm{x} \quad \mathrm{x}$

$\mathrm{x} \quad \mathrm{x}$

$\mathrm{x}$

$\mathrm{X}$

$\mathrm{X}$

$\mathrm{x}$

$\mathrm{x}$

$\mathrm{x}$

$\mathrm{x}$

$\mathrm{X}$

x $\quad \mathrm{x}$

$\mathrm{X}$

X

X $\mathrm{x}$

$\mathrm{X}$

$\mathrm{X}$

X

$\mathrm{X}$

$\begin{array}{lll}\mathrm{X} & \mathrm{X} & \mathrm{X} \\ \mathrm{X} & & \\ \mathrm{X} & & \\ \mathrm{X} & & \end{array}$

$\mathrm{X}$

$\mathrm{x}$
$\mathrm{x}$
$\mathrm{x}$
$\mathrm{x}$
$\mathrm{x}$


Rumex orbiculatus

Sagittaria latifolia

Salix amygdaloides

Salix bebbiana

Salix candida

Salix exigua

Salix lutea

Salix spp.

Schizachyrium scoparium

Scirpus pungens

Scirpus validus

Scutellaria galericulata

Scutellaria lateriflora

Senecio riddellii

Shepherdia argentea

Sidalcea neomexicana

Sisymbrium altissimum*

Sisyrinchium montanum

Sium suave

Smilacina stellata

Solidago canadensis

Solidago gigantea

Solidago rigida

Solidago missouriensis

Solidago occidentalis

Solidago spp.

Sonchus asper

Sonchus arvensis

Sonchus uliginosus

Sorghastrum nutans

Spargarium eurycarpum

Sparganium emersum

Spartina gracilis

Spartina pectinata

Sphenopholis obtusata

Spiranthes cernua

Sporobolus airoides

Stachys palustris

Suaeda calceoliformis

Suaeda depressa

Symphoricarpos occidentalis

Taraxacum laevigatum

Taraxacum officinale

Thalictrum dasycarpum

Thelypodium integrifolium
MT ID NE CO UT UT WY

(Uinta) (Wasatch)

$\mathrm{X}$

$\mathrm{x}$

$\mathrm{X}$

$\mathrm{X}$

$\mathrm{X}$

$\begin{array}{lll}x & x & x\end{array}$

$\mathrm{X}$

$x ? \quad x \quad x$

$\mathrm{x}$

$\mathrm{x}$

$\mathrm{X}$

$\mathrm{x}$ $\mathrm{x}$

$\mathrm{X}$

$\mathrm{x}$

$\mathrm{x}$

$\mathrm{x}$

$\mathrm{X}$

X

$\mathrm{X}$

X

X

$\mathrm{X}$

$\mathrm{X}$

$\mathrm{x}$

$\mathrm{X}$

$\mathrm{X}$

$\mathrm{X}$

X

$x$
$x$

$\mathrm{x}$

$\mathrm{X}$

$\mathrm{X}$

$\mathrm{X}$

$\mathrm{x}$

$\mathrm{X}$

X 
MT ID NE CO UT UT WY

Thelesperma filifolium

Thelypteris palustris

(Uinta) (Wasatch)

Tragopogon dubius*

Trifolium frageriferum*

Trifolium pratense*

Trifolium repens*

Triglochin maritima

Triglochin palustris

Triglochin spp.

Typha latifolia

Urtica dioica

Utricularia intermedia

$\mathrm{x}$

$\mathrm{X}$

$\mathbf{X}$

$\mathrm{x}$

Verbena hastata

$\begin{array}{llll}x & x & x\end{array}$

$\mathrm{X}$

$\mathrm{x}$

$\mathrm{x} \quad \mathrm{x}$

$\mathrm{x} \quad \mathrm{x}$

$\mathrm{x}$

$\mathrm{X}$

$\mathrm{X}$

$\mathrm{X}$

$\mathrm{X}$

Verronica anagallis-aquatica

Viola nephrophylla

Viola spp.

$\mathrm{x}$

$\mathrm{X} \quad \mathrm{X}$

$\mathrm{X}$

$\mathrm{X}$

X 
Ute ladies'-tresses (Spiranthes diluvialis) is a threatened plant species at the northern end of its range in Montana. The purpose of this monitoring study is to document the demographic trends in the population represented by EO\#001, and to identify critical life history stages. It may serve in the future for management response monitoring at a site where management practices are under review.

Mature plants may be in any of three stages from year-to-year, including flowering, non-flowering (vegetative) and seasonally dormant (persisting belowground). They are only dependably located when they are in flower, or when precise locations are recorded, so that repeat years of monitoring will establish base population numbers. Mature plants do not remain in a vegetative state for more than one year (Arft 1995b, Riedel et al. 1995), but the unknown duration of seasonal dormancy has not been determined. Reports in the literature indicate that Spiranthes magnicamporum may go for 20 years without flowering (Magrath 1979 in U.S. Fish and Wildlife Service 1995a).

Arft (1995b) identified the flowering stage as the critical life history phase among mature plants in plots subject to early-season haying and grazing, as well as to vole herbivory. The information from this previous monitoring study warrants further consideration in its application to this monitoring project.

\section{Methods}

The monitoring quadrat was established to track the entire population represented in EO\#001. One meter rebar stakes pounded to within $0.3 \mathrm{~m}$ of the surface mark the four corners of the plots above the wetland margins. The northern pair of rebar stakes do not quite extend as far north as the population, but are placed within $2 \mathrm{~m}$ of the maximum population extent at locations selected for their inconspicuousness among the shrubs in casual observation and non-interference with livestock movement.

The plot is read like an $\mathrm{x}, \mathrm{y}$ graph with a 30 meter tape spread along the southern boundary as the " $\mathrm{x}$ axis" (facing north), and a $30 \mathrm{~m}$ stretched along the northern boundary, for consistent orientation of the "y axis" between tapes. A single tape was moved along the $y$ axis and a meter stick was used to delimit $1 \times 1 \mathrm{~m}$ areas. Individual plants are mapped by their coordinates to within at least $0.1 \mathrm{~m}$ within each occupied $1 \times 1 \mathrm{~m}$ subplot. The numbers of buds (unopened flowers; B), open flowers $(\mathrm{F})$, and fruits (R), and any aborted flowers (a) were recorded per flowering stem. Stems closer than $2 \mathrm{~cm}$ together were treated as shoots from the same plant. The total number of basal leaves for vegetative plants was noted. Any browsing (b) or trampling ( $t$ ) were also noted.

Emergence and bolting of flowering stalks in the population have been staggered over 3-4 weeks (pers. obs.) so monitoring was timed at the end of the emergence period when all late stalks have emerged in bud, and flowering or already matured stalks are still visible (August x, 1996 and September 4, 1997). Some of the plants flowering at the beginning of the period were browsed by the end of the period, but remnants of the plants were still discernible. 
The species is restricted to relatively narrow wetland margin bands at the site. The plot layout requires care that the investigator avoid trampling the plant in moving up the $\mathrm{Y}$ axis. The most prudent measure is for the investigator to avoid placing any steps in the wetland margin habitat.

The raw data is presented below.

\section{DEMOGRAPHIC MONITORING OF UTE LADIES'-TRESSES

$1996 \quad 1997$

$1 \times 1$ subplot \#R,F.B \#R,F,B

0,6 a B-very immat. $6 \mathrm{R}, 7 \mathrm{~F}$

b $\quad 7 \mathrm{R}, 1 \mathrm{~F}, 1 \mathrm{a}$

0,7 a $10 \mathrm{~F}, 3 \mathrm{~B} \quad-$

b $\quad 1 \mathrm{~F}, 8 \mathrm{~B} \quad 1 \mathrm{Lb}$

c $\quad 8 \mathrm{~F}, 5 \mathrm{~B} \quad 5 \mathrm{Lb}$

$1,8 \quad \mathrm{a} \quad 7 \mathrm{R}, 2 \mathrm{a}$

$2,3 \quad$ a $\quad 0 F, 11 B \quad 7 R, 2 a$

b $\quad 3 F, 8 B \quad 4 R, 7 F$

c $\quad 12 \mathrm{R}, 3 \mathrm{a}$

$2,4 \quad \mathrm{a} \quad 1 \mathrm{~F}, 10 \mathrm{~B} \quad 9 \mathrm{~F}$

b $\quad 1 \mathrm{~F}, 10 \mathrm{~B} \quad 2 \mathrm{R}, 5 \mathrm{a}$

c $7 \mathrm{~L}$

d $2 \mathrm{R}, 1 \mathrm{~F}+$ brows.

2,8 a $\quad 7 F, 2 B \quad-$

4,2 a $13 \mathrm{~F} \quad$ B-very immature

4,3 a $0 \mathrm{~F}, 15 \mathrm{~B} \quad 3 \mathrm{~L}$

b 2F, 9B -

c $3 \mathrm{~L} \quad 4 \mathrm{R}, 1 \mathrm{a}$

d $\quad 11 \mathrm{~F}, 2 \mathrm{~B} \quad 3 \mathrm{~L}$

e $\quad 9 \mathrm{~F} \quad 2 \mathrm{~L}$

f $9 \mathrm{~F} \quad-$

4,4 a (browsed stem) -

b $\quad 3 \mathrm{~F}, 8 \mathrm{~B} \quad$ ?R, 1a

c $11 \mathrm{R}, 1 \mathrm{a}$

$5,2 \quad$ a $\quad 15 \mathrm{~F}$

5,3 a (two stems -

from one base - browsed)

b (browsed stem) -

5,4 a $2 \mathrm{~L}$

b $\quad 11 \mathrm{R}, 4 \mathrm{a}$

6, 4 a (browsed stem) -

6,17 a $15 \mathrm{R} \quad 10 \mathrm{R}, 7 \mathrm{a}$

a2 9R, 6a

7,2 al $11 \mathrm{R}$

a2 $17 \mathrm{~F}$,

7,3 a $10 \mathrm{R}, 3 \mathrm{~F}, 0 \mathrm{~B} \quad 3 \mathrm{R}, 1 \mathrm{a}$

b $\quad 8 \mathrm{~F}, 5 \mathrm{~B} \quad 5 \mathrm{R}, 11 \mathrm{~F}$ 


$\begin{array}{rlll} & \text { c } & & 6 \mathrm{R}, 3 \mathrm{a} \\ 7,14 & \mathrm{a} & \text { 0F, 7B } & 10 \mathrm{R}, 3 \mathrm{a} \\ & \mathrm{b} & \text { 0F, 8B } & 2 \mathrm{~L} \\ & \mathrm{c} & & 7 \mathrm{R}, 2 \mathrm{a} \\ 7,17 & \mathrm{a} & 2 \mathrm{~F}, 11 \mathrm{~B} & 101,4 \mathrm{a} \\ & \mathrm{b} & & 8 \mathrm{R}\end{array}$

\begin{tabular}{|c|c|c|c|}
\hline 9,5 & $\mathrm{a}$ & $0 \mathrm{~F}, 11 \mathrm{~B}$ & $3 \mathrm{Lb}$ \\
\hline 11,5 & $\mathrm{a}$ & & $12 \mathrm{R}, 3 \mathrm{a}$ \\
\hline 13,5 & $\mathrm{a}$ & $7 F, 4 B$ & - \\
\hline 14,6 & $\mathrm{a}$ & $5 \mathrm{~F}, 4 \mathrm{~B}$ & $6 \mathrm{~L}$ \\
\hline 14,22 & a & $9 \mathrm{~F}$ & - \\
\hline 17,6 & a & $17 \mathrm{~F}$ & - \\
\hline 17,19 & $\mathbf{a}$ & $5 \mathrm{~F}, 6 \mathrm{~B}$ & - \\
\hline \multirow[t]{3}{*}{18,2} & a & $1 \mathrm{~F}, 4 \mathrm{a}-$ & \\
\hline & $b$ & $15 \mathrm{~F}, 2 \mathrm{~B}$ & - \\
\hline & c & $10 F, 5 B$ & - \\
\hline \multirow[t]{2}{*}{18,3} & $\mathrm{a}$ & $15 \mathrm{~F}$ & $6 \mathrm{~L}$ \\
\hline & $\mathrm{b}$ & $5 F, 4 B$ & R15 \\
\hline 18,4 & $\mathrm{a}$ & $13 \mathrm{~F}$ & - \\
\hline 19,2 & a & $4 F, 13 B$ & - \\
\hline \multirow[t]{2}{*}{19,5} & $\mathrm{a}$ & $15 \mathrm{~F}, 0 \mathrm{~B}$ & $1 \mathrm{~L}$ \\
\hline & $\mathrm{b}$ & $9 \mathrm{~F}, 2 \mathrm{~B}$ & - \\
\hline 20,21 & a & $12 \mathrm{~F}, 5 \mathrm{~B}$ & $3 \mathrm{~L}$ \\
\hline 21,2 & $\mathrm{a}$ & & $8 \mathrm{R}, 3 \mathrm{~F}, 2 \mathrm{a}$ \\
\hline \multirow[t]{4}{*}{21,20} & a & $11 \mathrm{~F}, 0 \mathrm{~B}$ & stem browsed \\
\hline & $b$ & $6 \mathrm{~F}, 7 \mathrm{~B}$ & $2 \mathrm{~L}$ \\
\hline & c & $2 \mathrm{~F}, 5 \mathrm{~B}$ & $2 \mathrm{~L}$ \\
\hline & d & $0 F, 9 B$ & $11 \mathrm{R}, 2 \mathrm{a}$ \\
\hline \multirow[t]{4}{*}{25,5} & $\mathrm{a}$ & & stem browsed \\
\hline & b1 & & 10R, 1A \\
\hline & b2 & & $8 \mathrm{R}, 3 \mathrm{a}$ \\
\hline & c & & $8 \mathrm{~F}, 3 \mathrm{a}$ \\
\hline 25,6 & $\mathrm{a}$ & & F6 \\
\hline 26,4 & a & & stem browsed \\
\hline 26,7 & a & & $10 \mathrm{R}, 1 \mathrm{a}$ \\
\hline 27,13 & a & $11 \mathrm{~F}$ & $2 \mathrm{Lb}$ \\
\hline 28,17 & a & $11 \mathrm{~F}$ & $9 \mathrm{R}, 3 \mathrm{a}$ \\
\hline
\end{tabular}

Total No. of Plants: 52 documented 
Appendix E. DRAFT Section 7 Guidelines for Spiranthes diluvialis in Montana

The following text represents new information for consideration in Section 7 consultation guidelines for Spiranthes diluvialis in Montana, added to existing draft guidelines (U.S. Fish and Wildlife Service 1995).

\section{Recommendations and Guidelines for Section 7 Consultation}

\section{Category 1: Surveys Required}

In Montana, it is recommended that the conditions for requiring surveys be narrowed to include only those counties from which the species is documented (Beaverhead, Gallatin, Jefferson and Madison), and only those soil series (Neen, Villy, Saypo and the Fairway-Threeriver-Rivra complex) from which it is documented. Published and unpublished soil series data is to be used until such time as a multi-county soil series map representing potential habitat is prepared. It is appropriate to narrow down the conditions to include only landscapes with wetland/riparian habitat.

Category 2: Surveys Encouraged

In Montana, there are no historical records, but surveys are recommended within the counties, watersheds, and intermontane valley settings not otherwise meeting the soil survey criteria above. They include the following watersheds, between 4000-5000 feet:

1002002-050 and 070 Lower Beaverhead River 10020003-050 Lower Ruby River 10020005-010 and 040 and 080 Jefferson River Possibly 10020007-170 Lower Madison River and 10020008-110 Lower Gallatin River

\section{Category 3. Surveys Optional}

In Montana, there is little basis for setting standards outside of southwestern Montana, and no optional survey standards are proposed.

\section{Survey procedures}

In Montana, the full extent of shallow meandered channels and swales occupied by the species cannot be reliably discerned on the ground without aerial photographs, which are necessary for systematic survey. Survey must be conducted during flowering (second week of August thru first week of September) to be considered effective.

\section{Disqualified habitat}

Comment: The 1995 Section 7 criteria for ruling out habitat as potential habitat do apply in Montana, though it is to be stressed that these criteria refer to the actual wetland habitat and not to the surrounding uplands. This is important because all of the surrounding uplands are in soil series that are characterized in their profile descriptions as "salt-affected." 
Appendix F. Soils data analysis from Spiranthes diluvialis sites

UNIVERSITY OF NEBRASKA-IANR

SOIL \& PLANT ANALYTICAL LABORATORY

139 KEIM HALL: LINCOLN, NE 68583-0916

TEL: (402)472-1571 FAX: (402)472-1396

F : \DAQSMART \LABSRC \M-158.LAB

Printed: 11-12-1997

As : CUSTRPT

File Descriptors

01) JOB NO.

11) DATE RECEIVED

12) PROJECT LEADER

13) PROJECT ID

14) ADDRESS

15) MATERIAL TYPE
$\mathrm{M}-158$

$10 / 21 / 97$

BONNIE HEIDEL

MONTANA NATURAL HERITAGE PROG 1515 E 6TH AVE. SOILS

\section{(116)}

$\mathrm{Lab}$

No.
(457) CUSTOMER DESC. 2
(2) WATER BUFFERED $\mathrm{PH}$
(4)

EXCESS

LIME

22976
22977
22978
22979
22980
22981
22982

$\begin{array}{llll}1 & \text { EO\#001 } & 7.78 & 7.00 \\ 2 & \text { EO BEAV } & 8.07 & 7.00 \\ 3 & \text { EO GALL } & 7.80 & 7.00 \\ 4 & \text { EO\#004 MAR } & 7.66 & 7.00 \\ 5 & \text { EO\#005 MAR } & 7.87 & 7.00 \\ 6 & \text { EO\#004 MEA } & 7.97 & 7.00 \\ 7 & \text { EO\#005 MEA } & 8.01 & 7.00\end{array}$

\begin{tabular}{|c|c|c|c|c|c|}
\hline & (7) & $(410)$ & (411) & (16) & (17) \\
\hline Lab & $\begin{array}{l}\text { POTASSIUM } \\
\text { PPM }\end{array}$ & $\begin{array}{l}\text { BRAY P. } \\
\text { PPM }\end{array}$ & ORG. MATTER & $\begin{array}{l}\text { ZN DTPA } \\
\text { PPM }\end{array}$ & $\begin{array}{l}\text { FE DTPA } \\
\text { PPM }\end{array}$ \\
\hline
\end{tabular}

$\begin{array}{rrrr}22976 & 311.0 & 1.840 & 7.92 \\ 22977 & 192.0 & 0.930 & 25.00 \\ 22978 & 302.0 & 1.660 & 10.45 \\ 22979 & 248.0 & 2.020 & 25.35 \\ 22980 & 530.0 & 1.130 & 9.50 \\ 22981 & 277.0 & 1.670 & 9.63 \\ 22982 & 193.0 & 2.190 & 20.52\end{array}$

3.00

2.72

2.08

2.88

2.60

1. 20

3.52
92.80

133.20

115.20

136.80

190.00

40.40

118.80
Lab

No.
(18)

(19)

MN DTPA PPM
(6)

SODIUM PPM
(28)

CONDUCT . MMHOS/CM
(40)

CEC CMOL/KG
(41)

$\mathrm{K}$ (EXCH) CMOL/KG

$\begin{array}{lll}22976 & 22.8 & 2.04 \\ 22977 & 55.2 & 0.76 \\ 22978 & 36.0 & 3.96 \\ 22979 & 62.0 & 1.76 \\ 22980 & 26.8 & 2.52 \\ 22981 & 10.8 & 1.44 \\ 22982 & 33.6 & 5.20\end{array}$

282.0
400.0
354.0
184.0
356.0
375.0
186.0

0.90
0.85
1.06
1.24
1.50
1.15
0.68

19.97

0.87

1. 32

1.08

1.71

1.77

0.96

0.86

$\begin{array}{ll}19.97 & 0.87 \\ 45.46 & 1.32 \\ 37.52 & 1.08 \\ 44.52 & 1.71 \\ 22.42 & 1.77 \\ 27.20 & 0.96 \\ 46.56 & 0.86\end{array}$


$\mathrm{F}: \backslash D A Q S M A R T \backslash L A B S R C \backslash M-158 . L A B$

Page: 2

\begin{tabular}{|c|c|c|c|c|c|c|}
\hline $\begin{array}{l}\text { Lab } \\
\text { No. }\end{array}$ & $\begin{array}{l}(42) \\
\mathrm{NA}(\mathrm{EXCH}) \\
\mathrm{CMOL} / \mathrm{KG}\end{array}$ & $\begin{array}{l}(65) \\
\text { MG EXCH } \\
\text { CMOL/KG }\end{array}$ & $\begin{array}{l}(66) \\
\text { CA EXCH } \\
\text { CMOL/KG }\end{array}$ & $\begin{array}{l}(70) \\
\text { PSA FLAG }\end{array}$ & $\begin{array}{l}(372) \\
\text { AMMONIA } \\
\text { PPM }\end{array}$ & $\begin{array}{l}(375) \\
\text { NITRATE } \\
\text { PPM }\end{array}$ \\
\hline 2976 & 1.45 & 9.09 & 51.99 & ?? & 3.60 & 2.50 \\
\hline 2977 & 4.66 & 24.70 & 62.22 & ?? & INSUF & INSUF \\
\hline 22978 & 2.16 & 15.04 & 60.49 & ?? & 6.40 & 5.30 \\
\hline 22979 & 2.14 & 14.97 & 68.51 & ?? & INSUF & INSUF \\
\hline 22980 & 2.18 & 14.72 & 52.59 & ?? & 5.50 & 2.60 \\
\hline 22981 & 2.15 & 15.42 & 58.02 & ?? & 4.70 & 2.60 \\
\hline 2982 & 1.43 & 29.20 & 59.92 & ?? & 5.10 & 2.30 \\
\hline
\end{tabular}


AGRONOMY DEPARTMENT ANALYTICAL LABORATORY UNIVERSITY OF NEBRASKA-LINCOLN

NAME. . Montana Natural Heritage Program

ADDRESS . 1515 E. 6th Ave

REF $M-158$

Helena, MT 59620

SAMPLE PERCENT PERCENT PERCENT PERCENT PERCENT IDENT. SAND COARSE FINE VERY FINE CLAY SILT SILT SILT

TEXTURAL CLASS

$\begin{array}{rrrrrrrl}1 & 1 & 64.14 & 13.26 & 10.20 & 2.04 & 10.36 & \text { SANDY LOAM } \\ 2 & 2 & 51.16 & 16.93 & 15.34 & 2.65 & 13.93 & \text { LOAM } \\ 3 & 3 & 42.76 & 23.35 & 15.56 & 2.59 & 15.73 & \text { LOAM } \\ 4 & 4 & 0.00 & 0.00 & 0.00 & 0.00 & 0.00 & \text { not } \\ \text { enough soil } \\ 5 & 5 & 59.95 & 17.39 & 9.20 & 1.53 & 11.93 & \text { SANDY LOAM } \\ 6 & 6 & 60.72 & 12.35 & 12.35 & 2.06 & 12.52 & \text { SANDY LOAM } \\ 7 & 7 & 32.20 & 32.76 & 20.08 & 2.11 & 12.85 & \text { SILT LOAM }\end{array}$




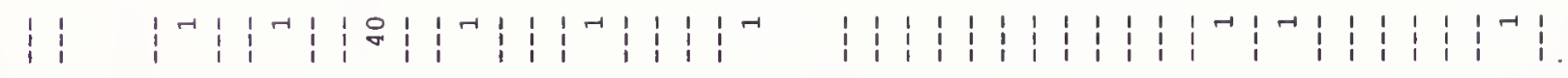
mo F!

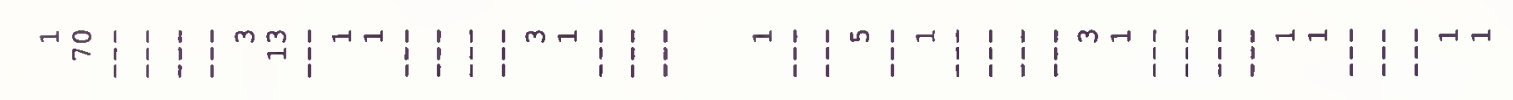
न-

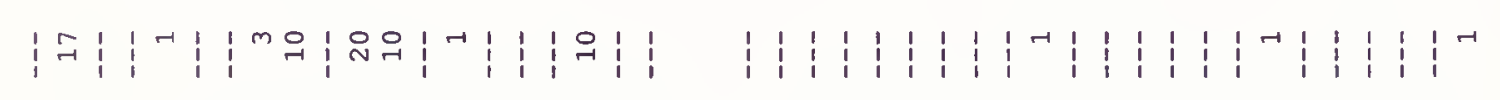

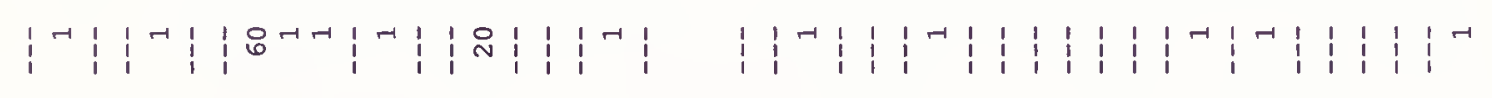
!

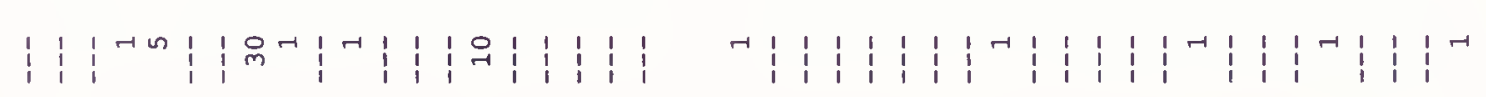


$\left|\mathcal{F}^{-1}\right| \vdots$

${ }^{m}:{ }^{-1}: \mid ⿰ r$

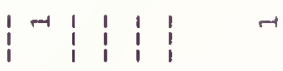

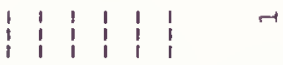

$11^{-1}: \mid \begin{aligned} & 1 \\ & 0\end{aligned}$

$\left|H^{-1}\right|{ }^{-1} \mid$ ก

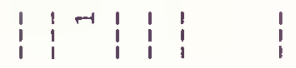

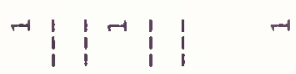

$1:\left.1^{-1}\right|^{-1}$

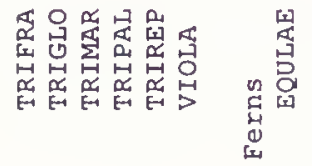




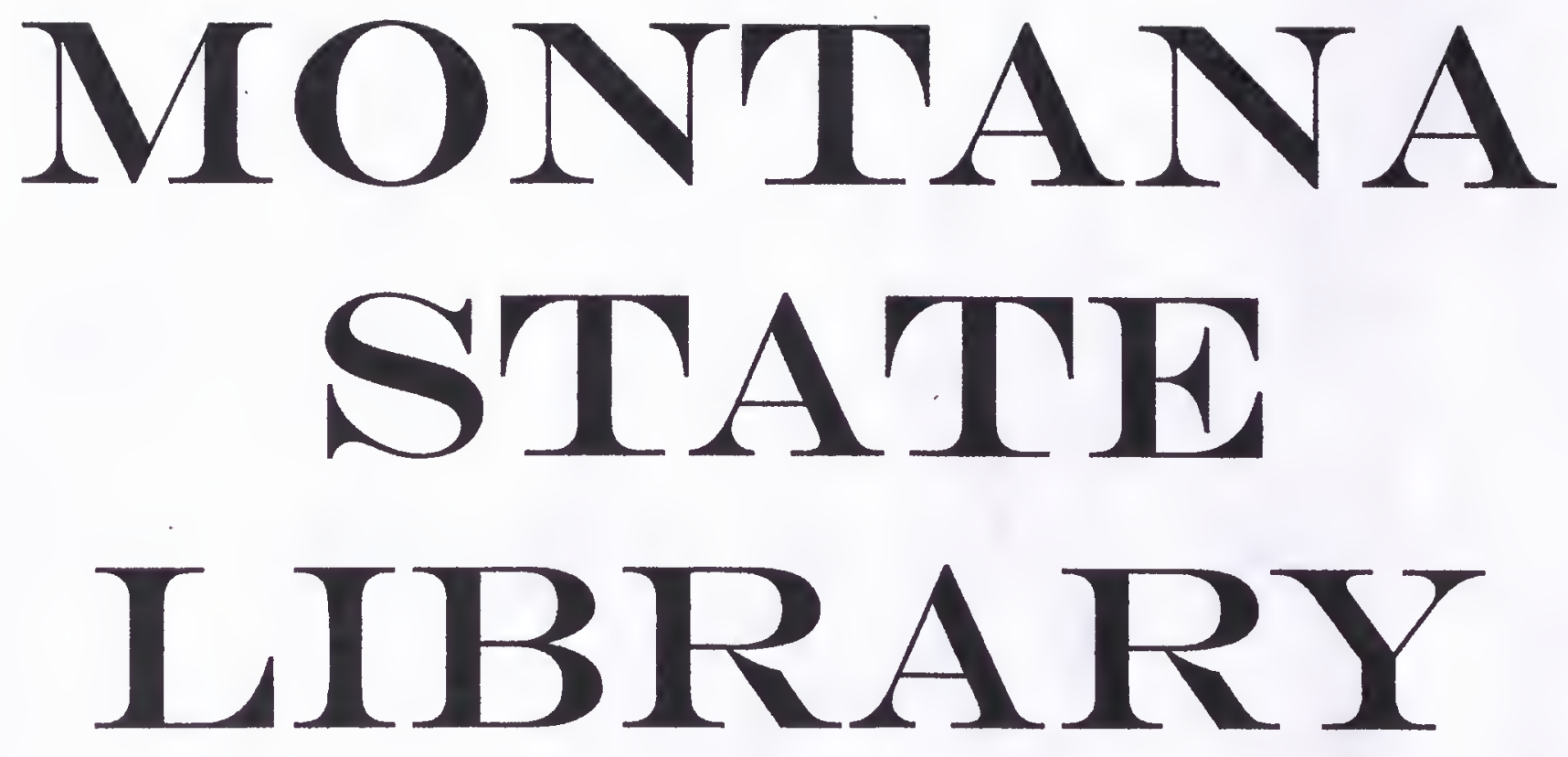

This "cover" page added by the Internet Archive for formatting purposes 